University of Redlands

\title{
Net Zero Water Study for Fort Irwin California
}

\author{
A Major Individual Project submitted in partial satisfaction of the requirements \\ for the degree of Master of Science in Geographic Information Systems \\ by \\ Oludamilola Eyelade \\ Ruijin Ma, Ph.D., Committee Chair \\ Mark Kumler, Ph.D.
}

December 2012 
Net Zero Water Study for Fort Irwin California

Copyright (C) 2012

by

Oludamilola Eyelade 
The report of Oludamilola Eyelade is approved.

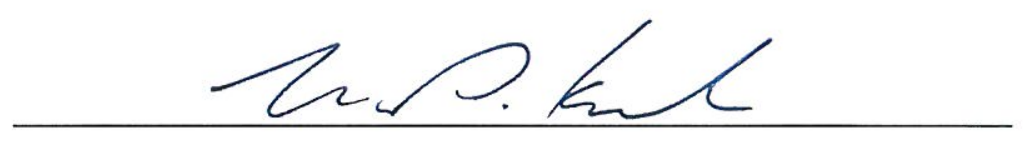

Mark Kumler, Ph.D.

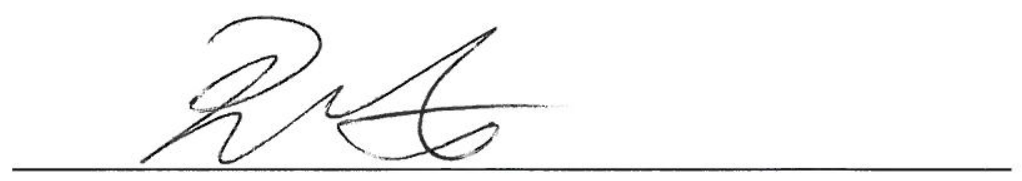

Ruijin Ma, Ph.D., Committee Chair

December 2012 



\section{Acknowledgements}

First I am grateful to the Morrison family trust for providing the funds that made it possible for me to attend the MS GIS program. Thanks to Chris Woodruff, the Client, who conceived the project and provided very specific goals. The client contact, Fon Duke was enthusiastic and ever willing to provide client side support.

My Supervisor, Dr. Ruijin Ma, quietly listened to all my ideas and ensured that I adopted only the reasonable ones. I am grateful for his invaluable suggestions and help on methods to improve the analysis. Dr. Mark Kumler asked those insightful questions that helped to improve the science behind the GIS. Early talks with Dr. Douglas Flewelling helped to ensure I understood the problem instead of going off on a fanciful tangent.

My parents Ayo and Yinka Eyelade chipped in parental love and advice as they have always done. My siblings and friends in Nigeria encouraged me throughout the course of this work. Bassey Andah, a great friend, and Charlie Frye gave advice from the design perspective and helped to improve the appearance of my illustrations. My classmates in Cohort 21, Debbie Riley, as well as Karen and Tony Mezzano were a wonderful adoptive family all through the year. 



\author{
Abstract \\ Net Zero Water Study for Fort Irwin California \\ by \\ Oludamilola Eyelade
}

Fort Irwin, a US Army base located in the Mojave desert area of California derives its water needs from aquifers underlying the Bicycle, Irwin, and Langford basins. At present natural recharge from the surface basins is not sufficient to balance water drawn from the aquifers. As part of efforts to improve aquifer recharge, a system was required to determine the volume of runoff generated in each basin as well as the feasibility and potential sites for storm water capture. This study used GIS to create models for basin delineation, runoff calculation and site suitability analysis for storm water capture. Outputs from these models made it possible to create maps showing estimated runoff volume and candidate sites for water capture within each storm water basin. The results also established the feasibility of storm water capture on Fort Irwin. 



\section{Table of Contents}

Chapter 1 - Introduction ................................................................................................ 1

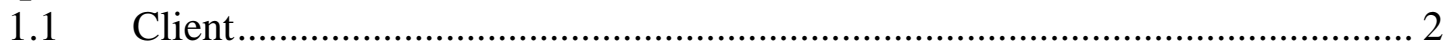

$1.2 \quad$ Problem Statement .......................................................................... 2

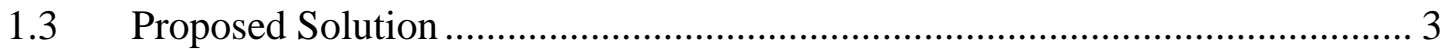

1.3.1 Goals and Objectives ............................................................................ 3

1.3.2 Scope

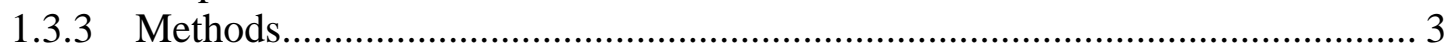

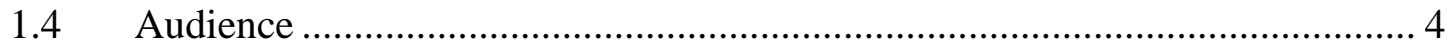

1.5 Overview of the Rest of This Report …………………............................ 4

Chapter 2 - Background and Literature Review ............................................................ 5

2.1 Rainfall Variability and Water Conservation in Arid Regions .......................... 5

2.2 Hydrological Models and GIS ................................................................. 6

$2.3 \quad$ Water Capture Site Identification with GIS ................................................... 8

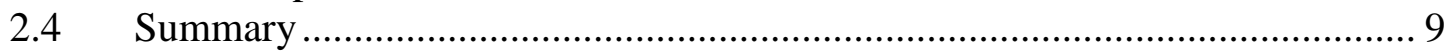

Chapter 3 - Systems Analysis and Design..................................................................... 11

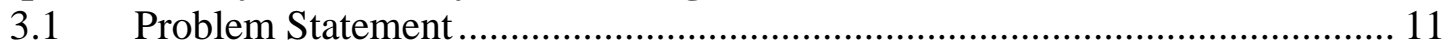

$3.2 \quad$ Requirements Analysis ............................................................................. 11

3.2.1 Functional Requirements ............................................................................ 11

3.2.2 Non-Functional Requirements ................................................................ 12

3.3 System Design .................................................................................... 14

$3.4 \quad$ Project Plan ....................................................................................... 15

3.4.1 Project Planning ................................................................................. 15

3.4.2 System and Database Design .................................................................. 15

3.4.3 System Implementation .......................................................................... 15

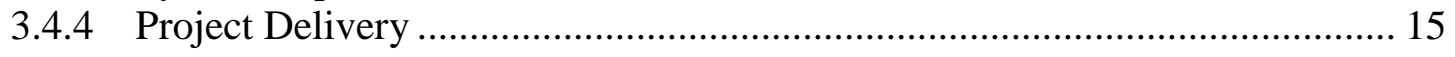

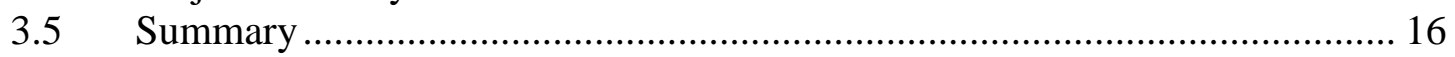

Chapter 4 - Database Design.................................................................................................. 17

4.1 Conceptual Data Model ..................................................................... 17

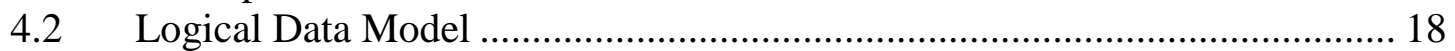

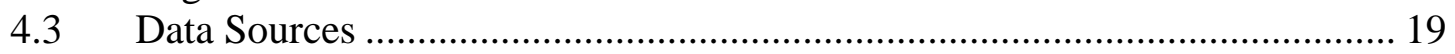

4.4 Data Scrubbing and Loading ………………............................................ 20

4.4.1 Elevation Data Preprocessing .................................................................. 20

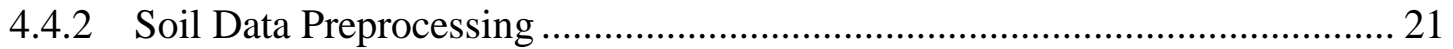

4.4.3 Land Cover Data Preprocessing................................................................... 22

4.4.4 Rainfall Data Processing .............................................................................. 23

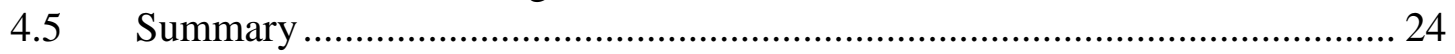

Chapter 5 - Implementation................................................................................... 25

$5.1 \quad$ Basin Preprocessing and Delineation......................................................... 25

5.1.1 Basin Preprocessing .............................................................................. 25

5.1.2 Basin Delineation.................................................................................. 27

5.2 Runoff Estimation Using the Curve Number Method .................................... 28

5.2.1 Mean Basin Curve Number Calculation Model............................................... 29 


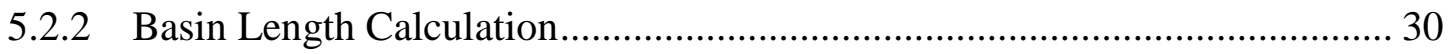

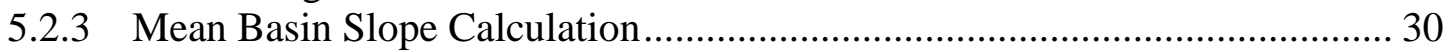

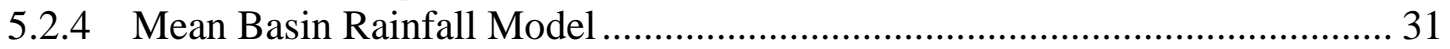

5.2.5 Runoff Volume and Peak Discharge Calculation ........................................... 31

5.3 Peak Discharge Estimation Using the USGS Method ..................................... 33

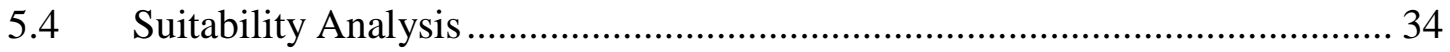

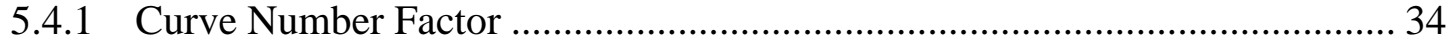

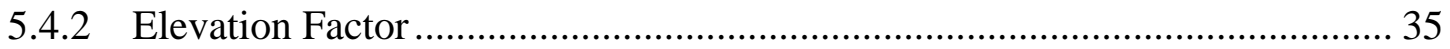

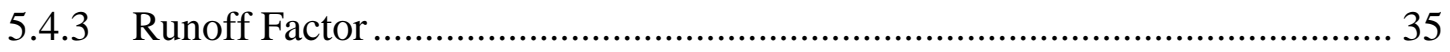

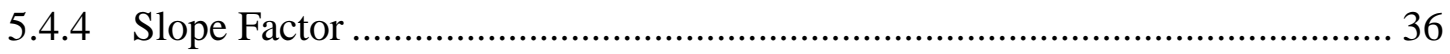

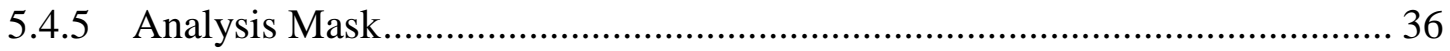

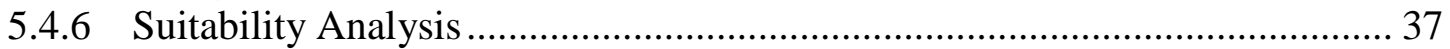

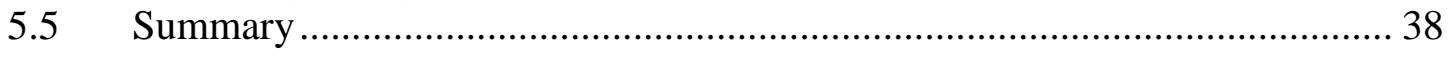

Chapter 6 - Results and Analysis.......................................................................... 39

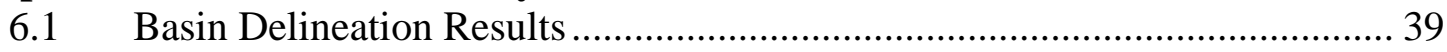

6.2 Peak Discharge Results and Analysis .......................................................... 41

6.3 Runoff Volume Results and Analysis........................................................... 44

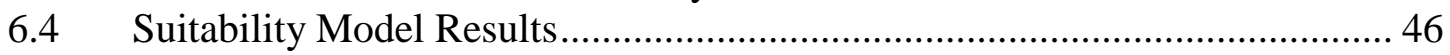

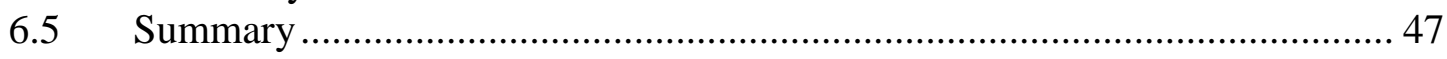

Chapter 7 - Conclusions and Future Work .................................................................. 49

Works Cited ……........................................................................................................... 51

Appendix A. Runoff and Suitability Analysis Models.................................................... 53

Appendix B. Python Code to Check for Existence of Fields........................................ 60

Appendix C. Aggregated Peak Discharge Results ............................................................ 63 


\section{Table of Figures}

Figure 1.1: Net Zero Water Use concept.......................................................... 1

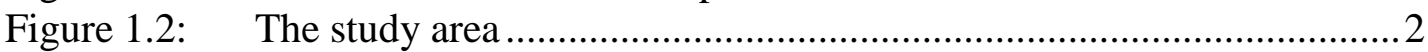

Figure 2.1: Methods of interfacing GIS and hydrologic models...........................

Figure 3.1: $\quad$ System design .......................................................................... 14

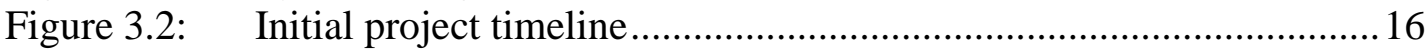

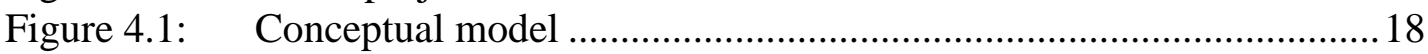

Figure 4.2: Logical model ........................................................................ 19

Figure 4.3: User interface of the SSURGO soil data viewer for Arcmap ............21

Figure 4.4: Using STATSGO data to fill in areas with no data ............................22

Figure 4.5: Curve Number lookup table............................................................2

Figure 4.6: Precipitation data conversion and projection model...........................24

Figure 5.1: Basin preprocessing workflow.....................................................2

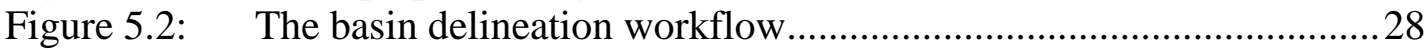

Figure 5.3: Curve Number method runoff estimation workflow ..........................28

Figure 5.4: Mean basin Curve Number calculation workflow ……………..........29

Figure 5.5: Basin length calculation workflow ……………………………......... 30

Figure 5.6: Mean Basin slope calculation workflow .............................................. 31

Figure 5.7: Mean basin rainfall calculation workflow .......................................... 31

Figure 5.8: The USGS peak discharge estimation workflow ……………..............33

Figure 5.9: Curve Number reclassification dialog box ..........................................34

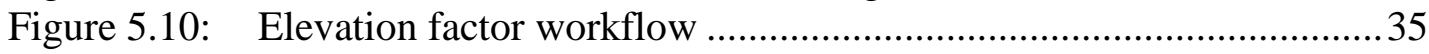

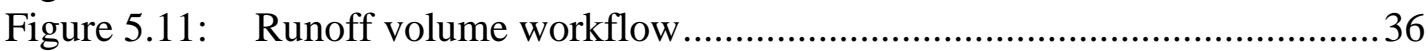

Figure 5.12: Percent slope reclassification dialog box ...........................................36

Figure 5.13: Analysis mask creation workflow......................................................37

Figure 5.14: Suitability analysis weighted overlay table.........................................38

Figure 6.1: Natural basins................................................................................. 39

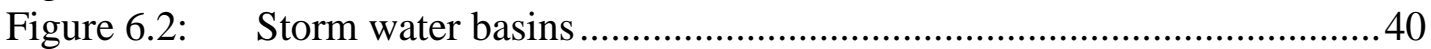

Figure 6.3: USGS HUC level 6 basins ......................................................... 41

Figure 6.4: Peak discharge results from USGS and Curve Number methods.......43

Figure 6.5: Runoff volumes for storm water basins ..............................................4 44

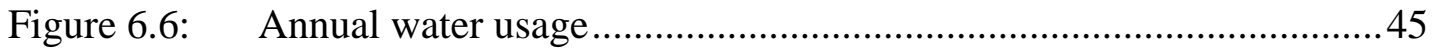

Figure 6.7: $\quad$ Ranked candidate water capture sites ...............................................46

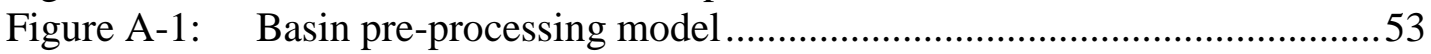

Figure A-2: Interactive basin delineation model .............................................54

Figure A-3: Mean basin curve number calculation model ......................................54

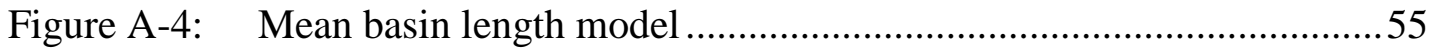

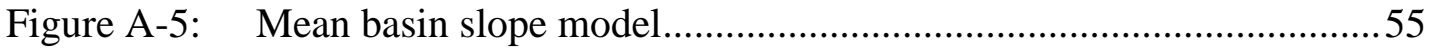

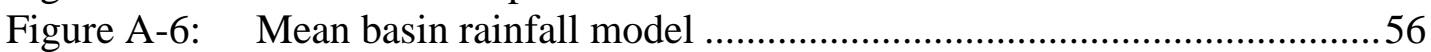

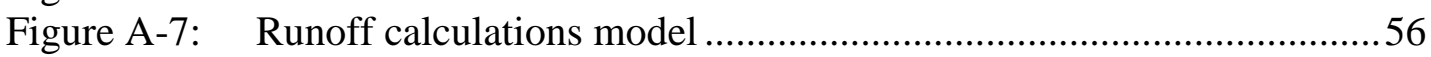

Figure A-8: Combined Curve Number runoff estimation model ............................57

Figure A-9: USGS peak discharge estimation model............................................57

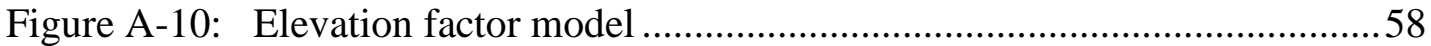

Figure A-11: Runoff factor model ..................................................................5 


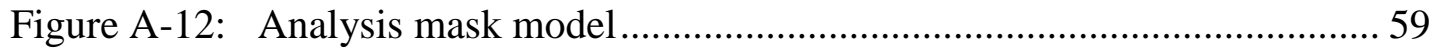

Figure A-13: Water capture suitability analysis model ...................................... 59 


\section{List of Tables}

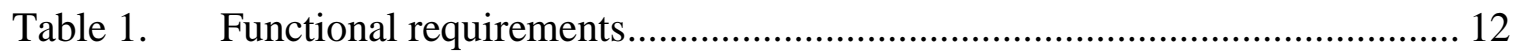

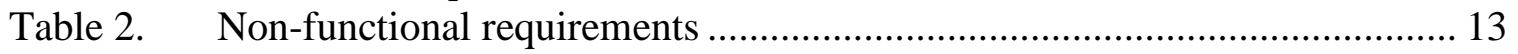

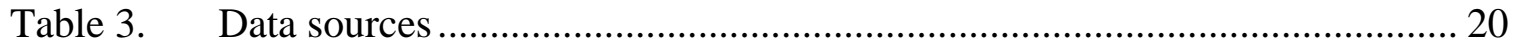

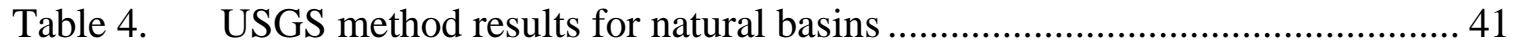

Table 5. USGS method results for HUC basins.................................................... 42

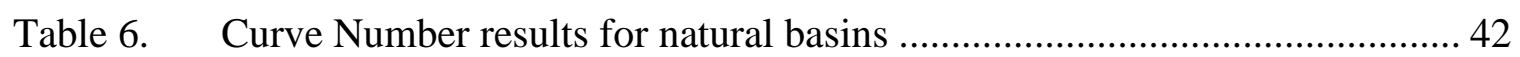

Table 7. Curve Number results for HUC basins .................................................... 43

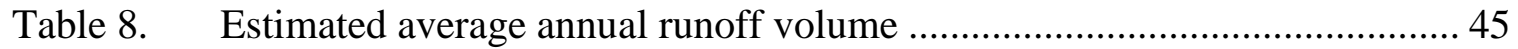

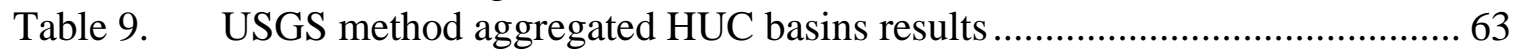

Table 10. Table 10 Curve Number method aggregated HUC basins results ................ 63 


\title{
List of Acronyms and Definitions
}

ArcGIS-SWAT
cfs
CN
DEM
GIS
HEC-HMS
HEC-RAS
HUC
IT
MDEP
MG
NED
NHD
NLC
NOAA
NRCS
PC
PFD
PRISM
RAM
SSURGO
STATSGO2
USGS
UTM
UML
WGS

\author{
ArcGIS Soil Water Assessment Tool \\ Cubic feet per second \\ Curve Number \\ Digital Elevation Model \\ Geographic Information Systems \\ Hydrologic Engineering Center Hydrologic Modeling System \\ Hydrologic Engineering Center River Analysis System \\ Hydrologic Unit Code \\ Information Technology \\ Mojave Desert Ecosystem Program \\ Million Gallons \\ National Elevation Dataset \\ National Hydrography Dataset \\ National Land Cover Dataset \\ National Oceanic and Atmospheric Administration \\ Natural Resources Conservation Service \\ Personal Computer \\ Precipitation Frequency Data \\ Parameter-elevation Regressions on Independent Slopes Model \\ Random Access Memory \\ Soil Survey Geographic Database \\ States Soil Geographic Database 2 \\ United States Geological Survey \\ Universal Transverse Mercator \\ Unified Modeling Language \\ World Geodetic System
}




\section{Chapter 1 - Introduction}

The US Army has begun a program aimed at implementing the Net Zero Water Use concept in its installations within and outside the United States in order to reduce the impact of its facilities on available fresh water resources (US Army, 2012) The goal of this concept is for a building or facility to achieve zero overall water use in a year by returning as much water as it withdraws from a source watershed. Net Zero Water Use is achievable through rain water capture, effective storm water flow management, treatment and reuse of waste water, and natural storage recharge (Cascadia Green Building Council, 2011). The relationship between Net Zero Water Use components is shown in Figure 1.1. Fort Irwin, a military base in California, is looking for ways to balance water use within the Net Zero Water Use framework. The present study examined the feasibility of storm water capture as a way of improving aquifer recharge.

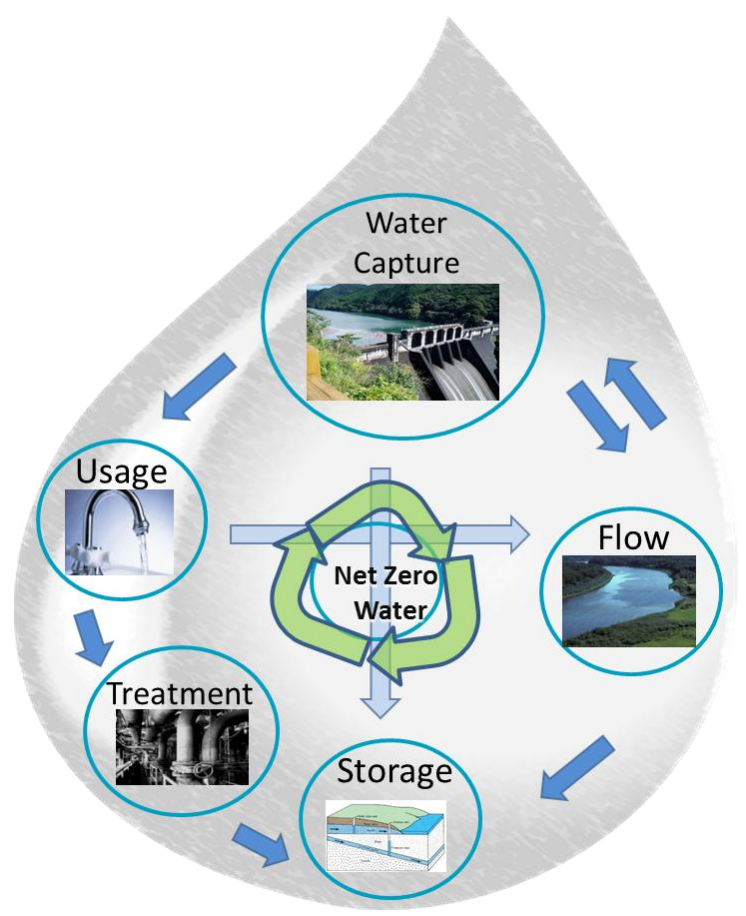

Figure 1.1: Net Zero Water Use concept

Fort Irwin is located in a desert environment within southern California, about 130 miles North of Los Angeles, and relies on aquifers for water (Densmore, 2003). The location of the study area and Fort Irwin is shown in Figure 1.2. The base wanted to explore the feasibility of rain water capture as a means for improving aquifer recharge and achieving Net Zero Water Use status. Geographic information system (GIS), a configuration of computer hardware and software for storage, retrieval, and analysis of geographic data, provides a means for modeling and analyzing the surface drainage basins within the study area. The Fort Irwin Net Zero Water Use study utilized GIS to create models for basin delineation, runoff calculations, and site suitability analysis for 
storm water capture. Outputs from these models made it possible to evaluate the quantity of water available from runoff and to create maps showing candidate sites for storm water capture within each storm water basin. Results from this study may be used to evaluate the feasibility of storm water collection as a method for aquifer recharge in the study area.

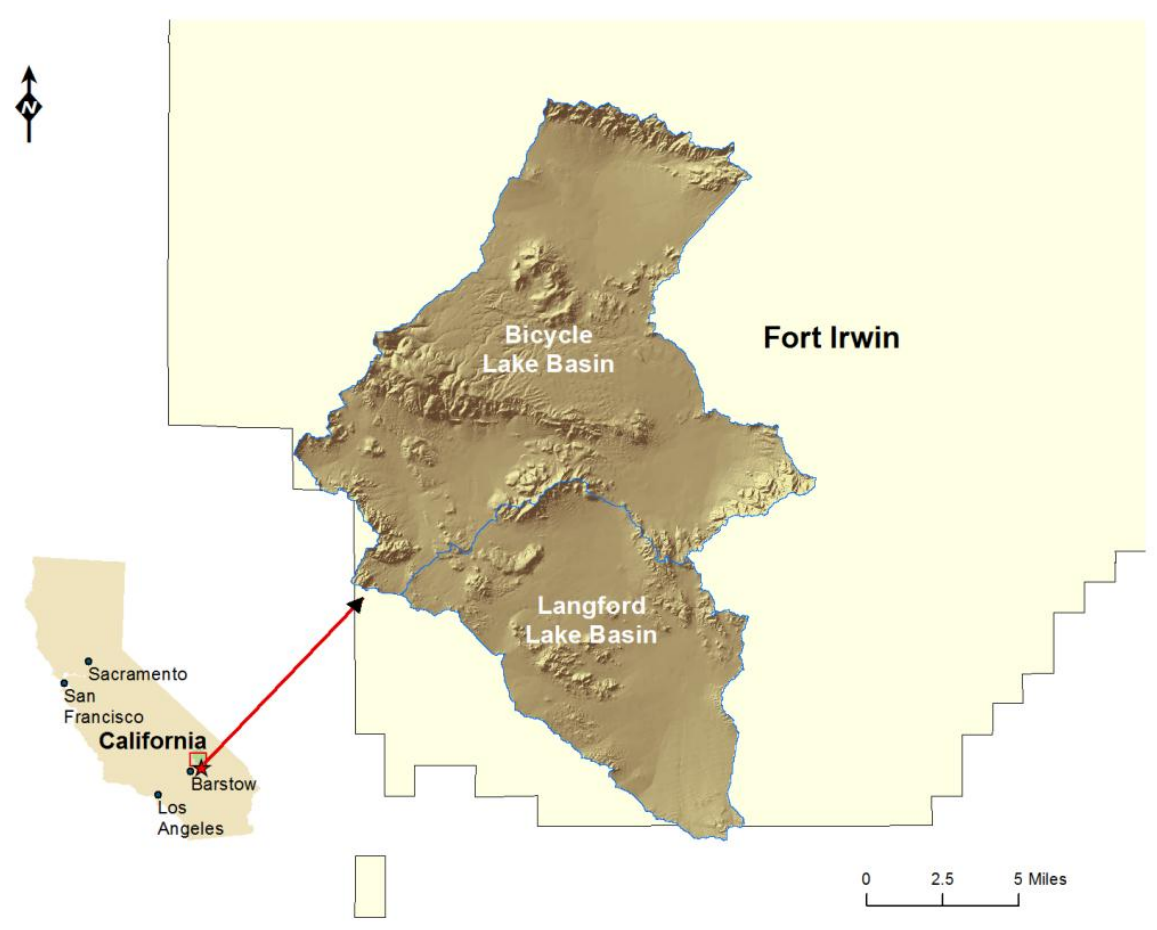

Figure 1.2: The study area

\subsection{Client}

The project client was Chris Woodruff, the Water and Wastewater Manager for Fort Irwin. The client wanted a GIS-based solution for runoff modeling and identifying potentially suitable sites for storm water capture to aid aquifer recharge. The primary contact was Fon Duke, the Program Manager of the Mojave Desert Ecosystem Program (MDEP), an organization that supports data sharing and information technology (IT) collaborative solutions for government agencies within the Mojave eco-region.

\subsection{Problem Statement}

Fort Irwin relies on ground water due to its arid location and low annual rainfall. Without deliberate efforts at recharge and conservation, the local water resource is not sustainable in the long run. To aid aquifer recharge, the client wanted to know how much runoff occurs from rainfall events within the storm water basins, and potential locations for storm water capture. This information would aid in determining the feasibility as well as possible locations for storm water capture to help achieve net water use balance. The 
client also wanted to delineate surface storm water basins which may not coincide exactly with known aquifer boundaries.

\subsection{Proposed Solution}

The proposed solution involved the development of three sets of geoprocessing models. First storm water basins were delineated using Esri Arc Hydro models. Next rainfall runoff models were built to determine the peak discharge and runoff volume for each delineated basin. Lastly a suitability analysis model was built to identify potential sites for storm water capture.

\subsubsection{Goals and Objectives}

The goal of this project was to determine the characteristics and locations of suitable rainwater capture sites for recharging underground water as part of efforts to achieve Net Zero Water Use at Fort Irwin.

The objectives of the project were:

- Delineate storm water basins

- Determine the volume of runoff from storms with different recurrence periods

- Develop a model to identify potential sites for storm water capture

\subsubsection{Scope}

This project and associated results were limited to the Bicycle, Irwin, and Langford storm water basins of Fort Irwin, California. The specific project scope was to estimate runoff parameters and determine potential water capture sites using methods that can be implemented in a desktop GIS environment.

\subsubsection{Methods}

Data for the project consisted of elevation data from the 10 Meter National Elevation Dataset (NED), land cover from National Land Cover Dataset (NLC), hydrography features from the National Hydrography Dataset (NHD), rainfall estimates from Precipitation Frequency Data (PFD) and Parameter-elevation Regressions on Independent Slopes Model Dataset (PRISM), soil data from Soil Survey Geographic Database (SSURGO) and States Soil Geographic Database 2 (STATSGO 2), and geology data from MDEP. All datasets were clipped to the Fort Irwin area and projected to World Geodetic System Datum 1984 (WGS84), Universal Transverse Mercator Zone 11 North (UTM Zone 11N).

Hardware for the project consisted of a personal computer (PC) running Windows 7 Operating System with 8 gigabytes of memory. Software included Esri ArcGIS desktop 10.0, Esri Arc Hydro tools 2.0, and ArcGIS Model Builder 10.0. Esri Arc Hydro was used in initial processing to create datasets required for use in later analysis to delineate the storm water drainage basins. Watershed processing to delineate the storm water basins was also carried out using Arc Hydro. Model Builder was used to create models that estimated runoff depth, volume, and peak discharge using the Natural Resources Conservation Service Curve Number method (NRCS-CN). A model was also built to 
estimate peak discharge using the United States Geological Survey (USGS) regression equation method. The runoff calculation models required basin attributes including basin area, mean basin Curve Number, basin length, mean basin slope, and mean basin rainfall as inputs. Models were also built to calculate each of the basin attributes required in the runoff calculation models.

Additional tools were developed in Esri Model Builder 10.0 that allowed for the interactive delineation of basins without using Arc Hydro. A weighted suitability model for identifying potential storm water capture sites was also developed. The input for this tool included elevation, runoff yield, slope, and Curve Number values. The final output of the suitability model was a map showing potential storm water capture sites.

\subsection{Audience}

This report discusses the use of GIS for the creation of tools and maps for identifying locations of potential storm water capture sites. The tools discussed in this paper are intended for use by professionals in water resources who are familiar with GIS and hydrological concepts. The output maps showing runoff volume and potential storm water capture sites are however intended for a wide variety of people who may have no knowledge of GIS but are affiliated with the US Army and have an interest in the results of this study.

\subsection{Overview of the Rest of This Report}

The rest of this report consists of chapters two to seven. Chapter Two presents a review of previous work on water conservation in arid areas, implementation of hydrological models in GIS and techniques for water capture.

In Chapter Three, the research problem is highlighted and a description of the requirements analysis for solving it is presented. The systems design is then outlined along with the plan for project implementation. A comprehensive description of the database is presented in Chapter Four, which opens with a discussion of the conceptual and logical model, followed by elaboration of the data sources, collection methods and how data was formatted for use within the GIS software.

Chapter Five details the process and tasks involved in implementing the project. Data analysis and results from different models are presented in Chapter Six. Chapter Seven consists of a condensed review of the whole document, conclusions and ways in which this study may be elaborated upon in future. 


\section{Chapter 2 - Background and Literature Review}

Increasing awareness of the limited nature of water resources, particularly in arid areas, is driving water conservation initiatives. Hydrological models that predict peak discharge and runoff volumes serve as aids to water conservation plans, such as water capture. Developments in GIS and hydrological modeling now make it possible to integrate the two for runoff prediction. Runoff parameters obtained can subsequently be used within a GIS to determine optimum rain capture sites. A short review of previous work on this subject helps situate the role of GIS in water conservation initiatives, particularly in arid areas.

\subsection{Rainfall Variability and Water Conservation in Arid Regions}

Uncertainty of precipitation is characteristic of arid and semi-arid regions. Many arid regions are now adopting water conservation methods as they face an increasing demand for water (Hammouri \& El-Naqa, 2007). Conservation methods have focused on reducing losses arising from household consumption and agricultural irrigation. Management approaches like the Net Zero Water Use concept seek to improve utility of available water by integrating conservation with environmentally friendly ways to recharge natural sources such as aquifers.

The high variability of rainfall and the need to conserve water in parched areas attract a lot of research interest (Comrie \& Broyles, 2002). Such studies use hydrological models to help conceptualize and characterize the relationships between rainfall and runoff volumes. To be effective in an arid environment, these models have to take the extreme variability of rain into consideration (Elfeki \& Al-Amri, 2011). Hydrological models that compute runoff involve the use of techniques including moving averages, regression models, Markov chains, and the Natural Resources Conservation Service (NRCS) Curve Number model.

Moving averages are used to analyze data by breaking them into smaller components and making inferences from the mean of each individual subset. Regression analysis examines the effect of varying the value of one variable on the value of another variable. The USGS developed several sets of regression equations which are applicable to and widely used for estimation of peak discharge from runoff in the United States (Thomas, Hjalmarson, \& Waltemeyer S D, 1997). Others have also developed regression models applicable on a small scale. For example, Comrie \& Broyles (2002) used an auto regression method to predict rainfall and river discharge in southern Arizona. A Markov chain models a future event based on the event immediately preceding it. Older events and their outcome have no effects on prediction. Elfeki \& Al-Amri (2011) used Markov chains to model the variability of rainfall and resultant runoff in Saudi Arabia. This study showed that it was much easier to model arid region rainfall and runoff with Markov chains than with moving averages or regression models.

The Curve Number was developed for predicting runoff from rain events using the soil moisture content, and land cover. The Curve Number method is fairly simple and is widely used with various small modifications around the world. The basic principle involves the calculation of a basin's Curve Number by adding the Curve Number values of all land cover and hydrologic soil group type combinations within it and finding a 
weighted average of the values. The hydrologic group of a soil is determined based on its minimum infiltration capacity. The groups are defined as A, B, C, and D, with group A soils having the highest infiltration rate while group $\mathrm{D}$ soils have the lowest. Tables that match appropriate Curve Number values to land cover/ hydrologic soil group combinations are available from the NRCS. (Natural Resource Conservation Services, 1986). Empirical models using the triangular hydrograph principle can be used to calculate runoff parameters with the basin Curve Number as an input (Soil Conservation Service, 1973). Hammouri \& El-Naqa (2007) used the Curve Number method for runoff modeling in Madoneh, Jordan. The Curve Number was also applied in estimating available runoff for water harvesting sites in the kilimanjaro region of Tanzania (Mblinyi, Tumbo, Mahoo, \& Mkiramwinyi, 2007). Ebrahimian et al. (2009), found it useful to modify the Curve Number method to account for slope while making runoff estimates in the Kardeh watershed of Iran.

With advancements in GIS, it is now possible to apply all these runoff estimation methods in combination with GIS. The calculation of average watershed Curve Number is straightforward but tedious to compute manually. Curve Number calculation models created within GIS can eliminate the tedium, reduce processing time, and be reused on different projects (McGee, 2009). GIS also makes it possible to use runoff results for identifying storm water capture sites.

\subsection{Hydrological Models and GIS}

There is a trend to introduce GIS into hydrologic modeling because of the growing recognition of the complexity of water resource problems and the need to effectively integrate input variables that have a spatial component (Martin, Lebeof, et al. 2005). Developments in GIS and hydrological modeling were initially unrelated (Stuart \& Stocks, 1993). However, the increased ability to manage and analyze large datasets and the user friendly interface of GIS led to its gradual convergence with hydrologic modeling. Several methods of interfacing the two systems have emerged, including linking, combination, and integration (Martin, Lebeof, et al. 2005). Linking allows data transfer via binary files, while combining is a method that allows data transfer via a database. Integration of a hydrological model with a GIS involves embedding the model so that it runs within the GIS. The diagrams in Figure 2.1 illustrate the three common ways hydrologic models can be interfaced with GIS. 


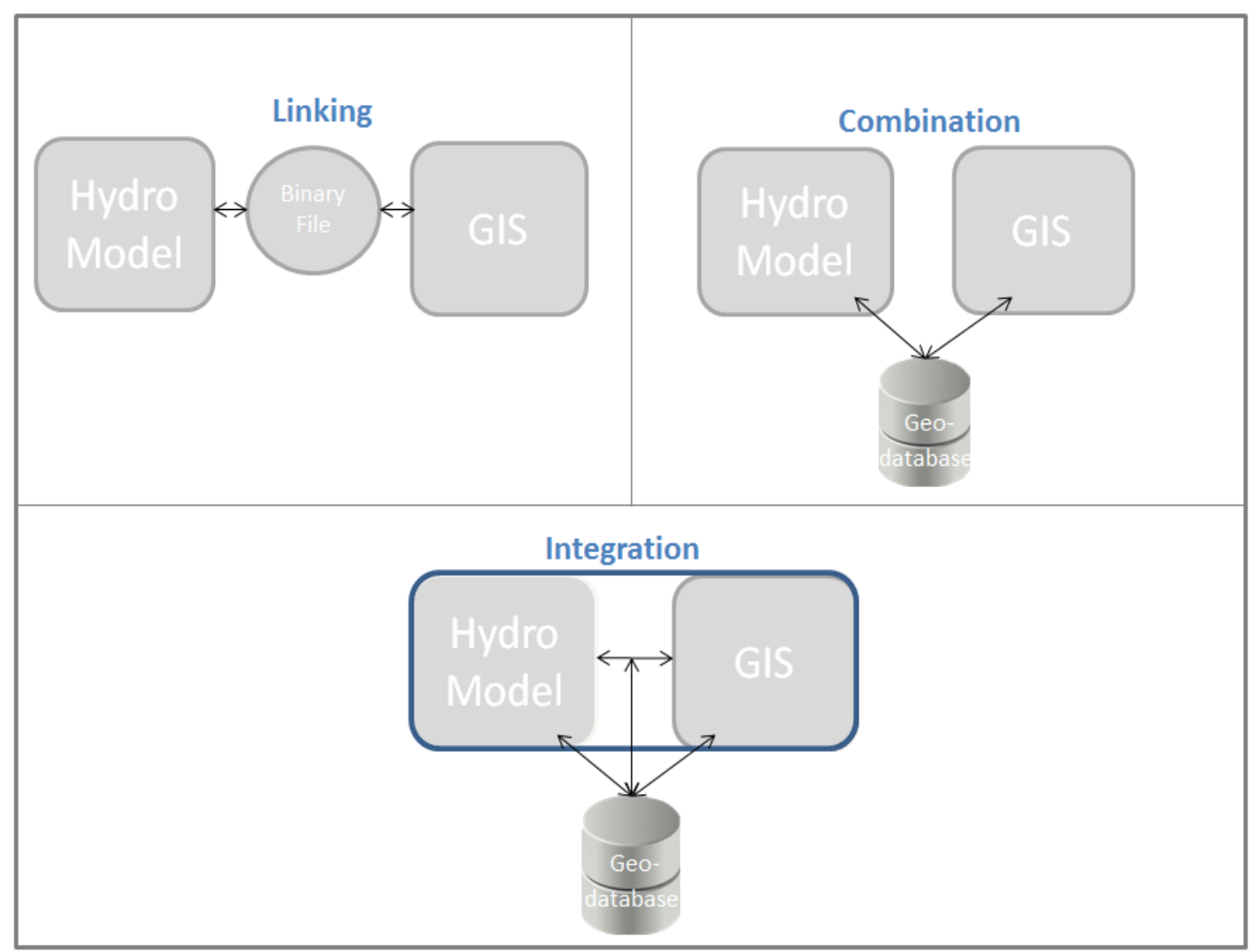

Figure 2.1: Methods of interfacing GIS and hydrologic models

Maidment (2002) developed Arc Hydro, a data model for surface water basins. This model supports simulations of hydrologic parameters over space and time. Its main functions are to model the relationships and connections between surface water features and to prepare data for use in hydrologic models. Through Arc Hydro, data can be exchanged with linked or combined hydrologic models. They can also be used with hydrologic models that are integrated with ArcGIS.

Several independent hydrological models, such as the US army hydrologic engineering center river analysis system (HEC-RAS), can be linked to GIS via binary files. Data transfer is however tedious. Models like the hydrologic modeling system (HEC-HMS) can be combined with GIS tools like the ArcGIS-Soil Water Assessment Tool (ArcGIS-SWAT). A setup like this allows data transfer between GIS and hydrologic models using a common database. Olivera et al. (2006) presented ArcGIS-SWAT and elaborated its use as a geodatabase model interface between ArcGIS and hydrological models. After initial calibration of the default runoff model, ArcGIS-SWAT was applied to runoff prediction in a creek in Texas. The GIS software was used to preprocess the DEM to derive initial water basin data which subsequently became input for the combined hydrologic model. The ArcGIS-SWAT module could also access the results of the hydrologic modeling software, as all project data were stored in the same geodatabase. Results from the hydrologic model were subsequently used as input data for GIS analysis. 
Some studies have developed hydrologic models that are fully integrated with GIS software. This approach makes modeling easier as all analysis and modeling activities can be carried out within the same software platform. Kirkby, Pegler, and Coleman (2011) developed an integrated model for estimating peak discharge and its effects on culverts in large watersheds. Their study embedded the hydrological model in ArcGIS, removing the need for data transfer between separate software systems. The model was calibrated and tested on an army base in Canada and proved very accurate in estimating rainfall discharge and predicting the ability of culverts to handle runoff.

The NRCS Curve Number method is often used when a hydrologic model is embedded in GIS, as most of such studies involve runoff calculations. In the ArcGIS environment, custom tools and models can be built to automate basin Curve Number and runoff calculations. Embedded Curve Number hydrologic models may be limited to specific studies or designed for wider use. Easterbrook (2006) developed a model for average basin Curve Number calculation in national parks within the United States. The basin Curve Numbers were then used in a raster-based model to estimate runoff depth and peak discharge for forested watersheds before and after wildfires. McGee (2009) took a more general approach and developed a Curve Number calculation model that can be used for different types of watersheds. McGee's model did not however generate runoff parameters, as the basin Curve Numbers were developed as input for HEC-HMS

It should be noted that embedding the hydrological model within GIS software makes it impossible to use the model independently of GIS. For studies that only model a few hydrologic parameters like runoff, an embedded model is preferable due to the associated nimbleness.

\subsection{Water Capture Site Identification with GIS}

Rainfall capture is a process that involves collecting water from runoff and storing it for future uses (Boers, 1994). There are several parameters to consider in the determination of suitable locations for capture sites. Commonly used parameters include runoff potential, water demand, size of collection area, distance between collection areas, slope, soils, geology, social factors, and financial outlay for capture site construction (Gupta, Deelstra, \& Sharma, 1997). Inamder et al. (2011) found that in an arid urban setting, runoff potential and water demand were the most important factors for determining suitable capture sites while other common parameters were secondary.

Other parameters may also be considered for rainfall capture site selection in arid regions because rainfall amount and duration are highly variable over time and space in such regions. Hammouri \& El-Naqa (2007) noted that arid rainfall capture sites are not supposed to capture runoff from all storms but rainwater discharge volumes that have low sediment load and that can be quickly absorbed by an aquifer. It was further noted that such capture sites can be ranked based on the quality of water in the underlying aquifer, how much of the recharged water would be drawn out again, and the likely ecological impact on the collection site. These additional factors are difficult to model and most studies of arid areas do not take all of them into consideration in identifying water capture sites. Studies that have not used these additional parameters in arid areas still 
achieved results useful for identifying storm water capture sites (Gupta, Deelstra, \& Sharma, 1997; Inamder et al. 2011; Sharma \& Singh, 2012).

Different studies gave varying amounts of influence to runoff in identifying water capture sites. Gupta, Deelstra, and Sharma (1997) divided their study area into sub-basins and ranked them based on runoff potential. Potential water capture sites were then identified in each sub-basin by using a weighted average of several social factors. A modification of this classification method involved further dividing each sub-basin into runoff zones, using Curve Number values before analyzing the impact of social and physical factors (Sharma \& Singh, 2012). Inamder et al. (2011) used the concept of accumulated basins, which involves aggregating individual sub basins that increase in size from upstream to downstream. A ratio of urban demand to runoff was calculated for each succesive accumulated basin and the discharge points of the basins with the highest ratios were identified as ideal locations for storm water capture.

It is possible to suggest various methods to use for water capture, based on runoff volumes and the physical characteristics of potential sites. For small areas, bare earth reservoirs also known as ndiva can be dug (Mblinyi, Tumbo, Mahoo, \& Mkiramwinyi, 2007). Stone or contour-bench terraces may also be created on steep slopes to slow down the water and allow for infiltration. In Arid areas, wadi bed and off wadi bed water capture systems are applicable (Oweis, Prinz, \& Hachum, 2001). Wadi bed systems can be deployed by digging small reservoirs near the flat downstream outlets of streams with intermittent flow. Water then flows into such reservoirs during rain storms. In off-wadi systems, runoff from intermittent wadi stream flow is diverted to very flat fields where other water capture techniques can aid infiltration into groundwater.

\subsection{Summary}

There is considerable interest in conserving water in arid areas, as shown by the amount of research studies from around the world on the subject. Such studies involved the computation of runoff as it is essential in determining the suitability of potential water capture sites. Several hydrologic models can be used in runoff estimation. The NRCS Curve Number is the most commonly used for runoff estimation because of its simplicity and widespread applicability. GIS and these hydrologic models can be incorporated for runoff estimation. Available methods for doing this include linking, combination, and integration. Runoff parameters obtained can subsequently be used within a GIS to determine optimum rain capture sites.

Hydrologic models integrated with GIS are particularly useful when runoff is the only hydrologic parameter to be calculated with such models. The integrated approach also eliminates the potentially cumbersome task of data transfer between separate software systems. 



\section{Chapter 3 - Systems Analysis and Design}

It is essential to understand the problem a project is set up to address, as this ensures effective planning and appropriate solution design. This chapter begins with a brief presentation of the project problem. This is followed by requirements analysis, system overview, and the project plan. The requirement analysis section discusses functional and non-functional requirements of the project solution. Hardware and software configurations required to make the solution work are discussed in the systems architecture section. A structured guide to keep the project focused and on schedule is presented in the project plan section. The chapter ends with a brief summary.

\subsection{Problem Statement}

Fort Irwin relies on aquifers underlying the Bicycle, Irwin, and Langford basins for its water needs. These aquifers cannot be sustained as water sources without deliberate efforts aimed at improving aquifer recharge. The client required procedures to determine the boundaries of the surface basins, the volume of runoff that occurs in them after rain storm events, and potential sites for storm water capture. The information derived from these procedures would help to evaluate the feasibility of storm water capture as a means of improving aquifer recharge in the study area.

\subsection{Requirements Analysis}

The requirements analysis involved getting a detailed understanding of what functions the client needed the proposed solution to perform. The required attributes of the solution were then determined and are discussed below under the headings of functional and nonfunctional requirements.

\subsubsection{Functional Requirements}

Functional requirements are system design considerations which ensure that the solution can perform the expected tasks and provide useful results. These include how the solution can be accessed, what can be done with it and data exchange capabilities. The functional requirements are listed below in Table 1. 
Table 1. Functional requirements

\begin{tabular}{|l|l|}
\hline Requirement & Description \\
\hline $\begin{array}{l}\text { Open, view import, export, save or print } \\
\text { map documents }\end{array}$ & $\begin{array}{l}\text { Maps may be viewed and modified using } \\
\text { default ArcGIS desktop functions }\end{array}$ \\
\hline Identify potential capture sites & $\begin{array}{l}\text { Change weights for site selection model } \\
\text { inputs }\end{array}$ \\
\hline Interactively delineate basins & $\begin{array}{l}\text { Interactively delineate the drainage basin } \\
\text { for a user specified point of interest }\end{array}$ \\
\hline Calculate runoff parameters & $\begin{array}{l}\text { Run tools that allow the determination of } \\
\text { peak discharge and runoff volumes for } \\
\text { user specified input basins }\end{array}$ \\
\hline Information from basin runoff attributes & $\begin{array}{l}\text { Query attributes to get information about } \\
\text { runoff volumes and peak discharge }\end{array}$ \\
\hline
\end{tabular}

Users need to be able to display, print and modify the ranked suitability maps from a symbolized Arcmap document. Attribute data must be accessible and provide information about suitability ranking, as well as runoff parameters. Tools in the project toolbox should make it possible to modify different inputs for the potential water capture site model. An interactive basin delineation function, basin peak discharge and runoff parameters calculation, as well as access to the peak discharge and runoff attributes is expected. Users must also be able to change the default storm event input data used for runoff parameters calculation if they so wish. A default geodatabase is required to store the original project output datasets and any new client outputs created by running project models. The ability to export or import data at will from the geodatabase is also expected.

The Fort Irwin water study project was built as an ArcGIS desktop application with map documents and a toolbox. The map documents included a ranked suitability map showing locations of potential water capture sites, as well as maps of delineated storm water basins. The project toolbox is for the desktop environment and may be installed on a network or operated on independent computers.

\subsubsection{Non-Functional Requirements}

The system specifications that allow for optimal performance of the GIS models are divided into technical, operational, and transitional requirements. These requirements are listed in Table 2. 
Table 2. Non-functional requirements

\begin{tabular}{|c|c|}
\hline Requirement & Description \\
\hline \multicolumn{2}{|c|}{ Technical Requirements } \\
\hline Processor and hardware specifications & $\begin{array}{l}\text { Processor: Intel recommended } \\
\text { Speed/RAM: } 2.2 \mathrm{GHz} \text { or higher, } \\
\text { Memory/RAM: } 2 \mathrm{~GB} \text { or higher. }\end{array}$ \\
\hline Software requirements & $\begin{array}{l}\text { Operating system: Windows PC (minimum } \\
\text { version Windows XP) } \\
\text { ArcGIS } 10.0 \text { desktop, with Spatial Analyst } \\
\text { extension. Arc Hydro recommended. }\end{array}$ \\
\hline \multicolumn{2}{|c|}{ Operational Requirements } \\
\hline Experience \& knowledge level & $\begin{array}{l}\text { Familiarity with hydrology concepts and } \\
\text { ArcGIS to use the model tools. No } \\
\text { experience required to use output maps. }\end{array}$ \\
\hline Maintenance & Minimal to none envisaged after setup. \\
\hline \multicolumn{2}{|c|}{ Transitional Requirements } \\
\hline Data format & $\begin{array}{l}\text { All data must be in ArcGIS readable } \\
\text { format. }\end{array}$ \\
\hline Model testing & $\begin{array}{l}\text { The models in the toolbox must be tested } \\
\text { extensively before delivery to client. }\end{array}$ \\
\hline Documentation and help files & $\begin{array}{l}\text { The model tools should be documented to } \\
\text { provide information about parameters. }\end{array}$ \\
\hline
\end{tabular}

Hardware specifications for this system include a minimum processor speed of $2.2 \mathrm{GHz}$ with at least $2 \mathrm{~GB}$ of RAM. The client's computer infrastructure met the minimum hardware specifications. The GIS software required included the Windows operating system, Esri ArcGIS desktop 10.0, and Spatial Analyst. The client could also install the Arc Hydro geo-data model and toolset. The GIS infrastructure at Fort Irwin does not currently utilize Arc Hydro or a hydrological model integrated with GIS but has all ArcGIS licenses required.

The project document and tools will be used by experienced ArcGIS users who expect an easy to understand application with a short learning curve. The project toolbox 
contains tools that embed runoff modeling workflows and equations within ArcGIS. Three storm water basins (Bicycle, Irwin, and Langford) can be analyzed using the project tools. The project lifespan is limited as the project products were created to determine runoff volumes and identify water capture sites. So there will be limited or no maintenance required once the system is up and running.

Pre-existing project data must be in ArcGIS format or formats that can be imported by ArcGIS. Export capability is also supported by ArcGIS desktop. The creation of embedded runoff calculation capabilities in the project toolbox would, however, reduce the need to export or import products to the formats used by traditional hydrological modeling software. The functionality of project tools was tested, extensively using study area data. To ensure a good user experience the project toolbox and model tools are documented to provide information about inputs, model workflow and the results generated.

\subsection{System Design}

System design was based the requirements analysis. All modules of the system were designed to run within the ArcGIS software system. Arc Hydro has some built in tools for generic hydrological functions such as basin delineation and hydrological network generation, and these were adopted for this project. DEM preprocessing and basin delineation, were done using Arc Hydro.

Custom model tools with functionality similar to Arc Hydro toolsets were created as a backup in case intended users do not have the Arc Hydro extension. Other model tools were created for data conversion, runoff calculation, and water capture suitability analysis. A geodatabase was created to support data entry, storage, and transfer between different project modules. Symbolized maps showing analysis results were stored in Arcmap documents. The system design diagram is presented in Figure 3.1.

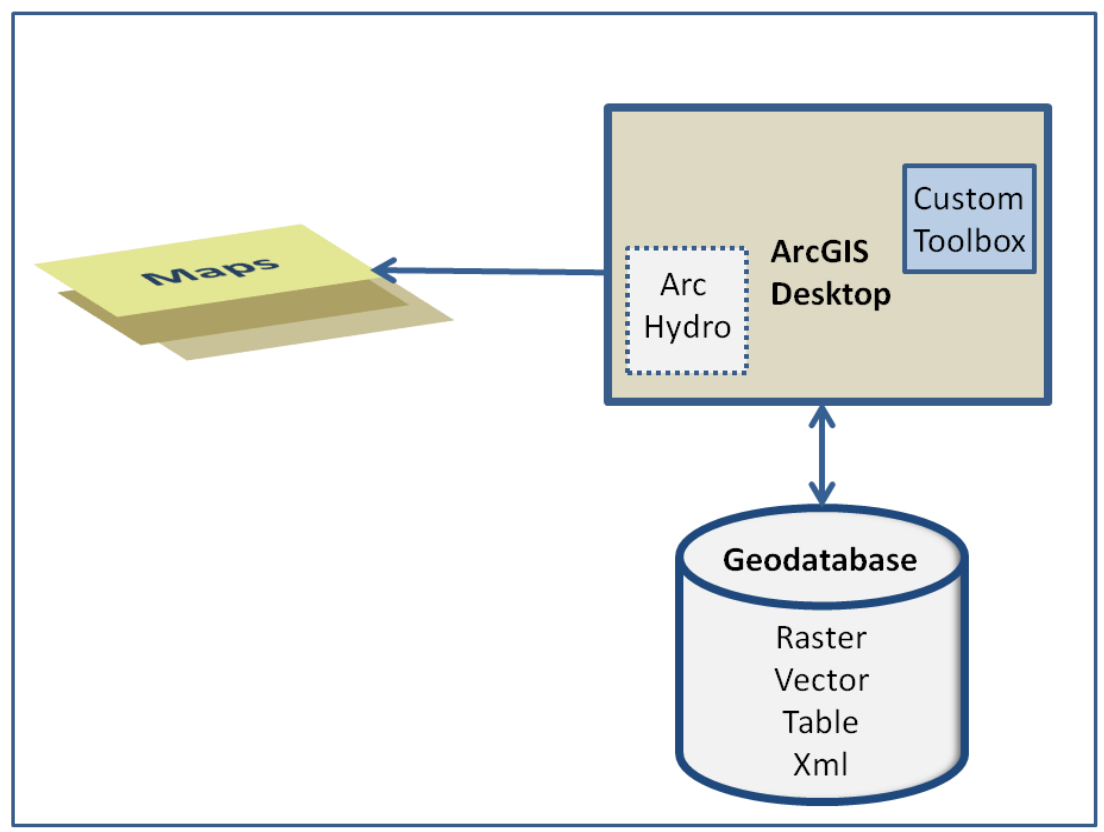

Figure 3.1: System design 


\subsection{Project Plan}

The project plan was developed to keep the project focused and on schedule. Milestones and a timeline were included to keep track of progress during the project lifecycle. The project was also divided into several stages, beginning with project planning. The other stages in order of planned execution were system and database design, system implementation, and project delivery. The project plan and minor modifications that occurred are discussed below.

\subsubsection{Project Planning}

An onsite meeting and several telephone conversations with the client helped to identify the problem and strategic goals. The project was scoped to identify coverage, while the requirements analysis helped to identify user needs and deliverables. The project plan was subsequently developed

\subsubsection{System and Database Design}

Based on functional analysis and interactions with the client, a conceptual model was created to represent the relationship between project elements. A geodatabase was then designed to manage actual data. The adoption of Arc Hydro and its accompanying data model made the geodatabase design easy, as Arc Hydro comes with its own default data attribute scheme and dataset organization. The Arc Hydro data model was adopted as a working prototype. A final geodatabase model was created during the project execution stage.

\subsubsection{System Implementation}

Project execution consisted of data exploration, determination of analysis techniques, model creation, and documentation. A considerable amount of time was spent on data exploration, as most of the data had to be preprocessed before analysis. Preprocessing techniques were not always easy to develop and several iterations were necessary to get the data into a usable form. Therefore, preprocessing took much longer than originally planned.

During model creation, mathematical equations and runoff workflows were embedded in ArcGIS using Model Builder. It was necessary to run the model tools several times to get the right configuration. The tools were documented and help files were created to explain inputs, model procedure, and results. A toolbox was then created to house all of the project tools. Map outputs were stored in an Arcmap document.

\subsubsection{Project Delivery}

The geodatabase, map documents, and tools were handed over to the client and the project was closed. Although the stages and processes did not change considerably during the project lifecycle, some processes in each stage took much longer than was expected. The initial project timeline is presented below in Figure 3.2. 


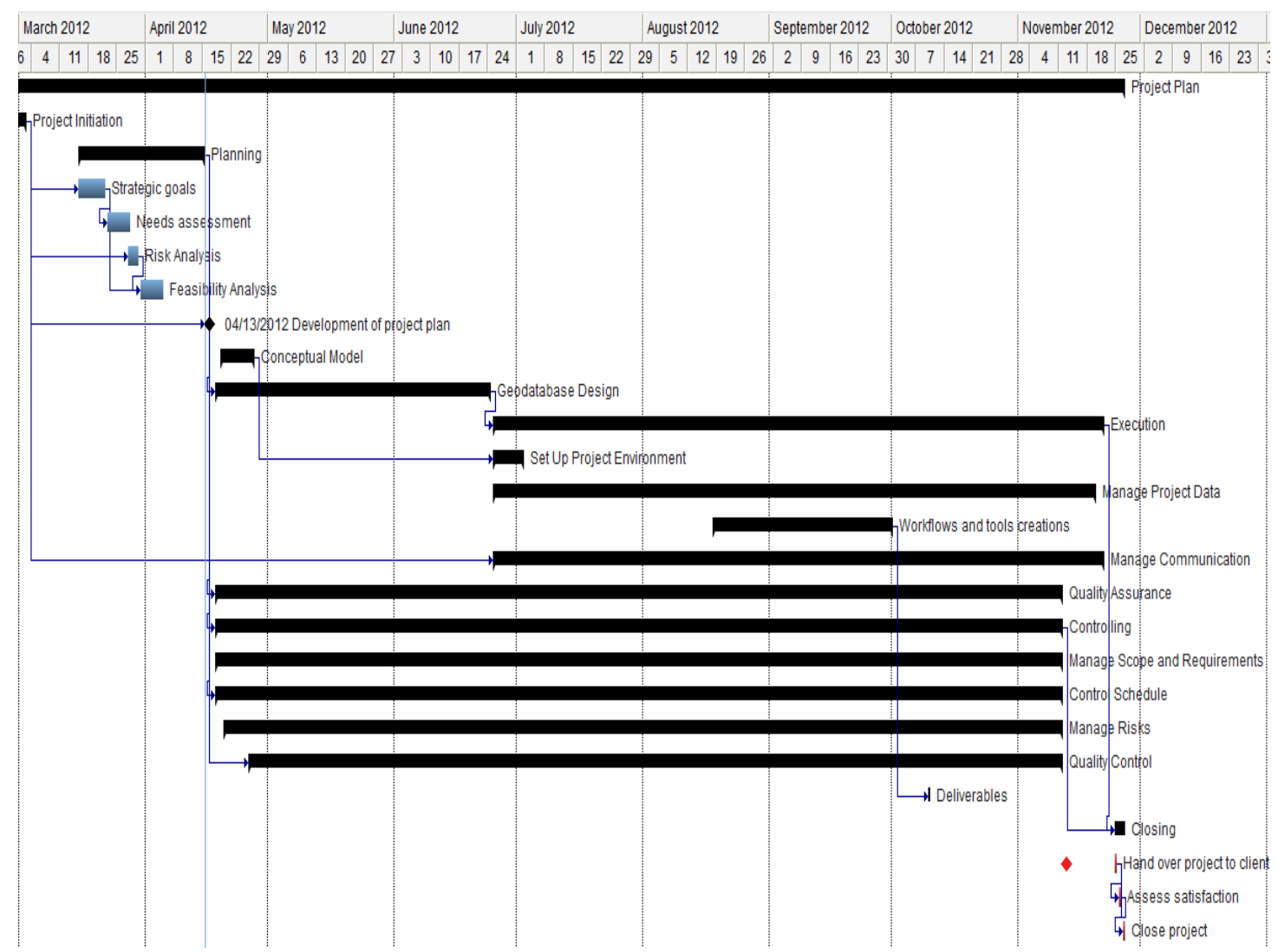

Figure 3.2: Initial project timeline

\subsection{Summary}

This chapter presented an overview of the project problem and the system design activities for creating the solution. The requirement analysis for the expected functional and non-functional requirements of the system was discussed in detail. The system architecture and plan for project implementation were also elaborated. 


\section{Chapter 4 - Database Design}

This chapter discusses the development of the conceptual and logical models, data sources, and acquisition methods. A database is required to model geographic entities, their attributes, and relationships. A conceptual model was created to idealize the entities and interrelationships. The logical model translated the conceptual model into a physical database. Datasets were collected from several sources and had to be preprocessed before loading into the database.

\subsection{Conceptual Data Model}

The conceptual model helps to present the relationships among the entities involved in the project problem. The entities include rainfall, water basins, rivers, soil, geology, and suitable water capture sites. Rain is the primary source of flowing water. Rain falling on water basins infiltrates through the soil into aquifers or becomes runoff. Runoff ends up in the river channels which flow in the storm water basins. The geology determines if and how much infiltration can occur. Using a combination of physical attributes of the storm water basins, it is possible to identify potential water capture sites.

A rain event can occur in water basins, providing the water that flows into rivers and recharges aquifers. Attributes of a rain event include duration and return period. The storm water basins and aquifers are subclasses of water basins. Several rivers flow in each storm water basin. The two subclasses are distinguished from each other by different attributes. The major distinction is that a storm water basin exists above the ground surface while an aquifer exists below the ground. Other storm water basin attributes include the number of rivers present, the volume of runoff, and peak discharge. The only other aquifer attribute is the volume of water storage.

Geology consists of rocks of varying types formed over multiple eras which underlie the water basins. Soil is differentiated based on hydrologic properties. It forms a loose covering over the geology, and is exposed at the surface of each basin. The combination of several physical factors helps to identify potential water capture sites which exist within each storm water basin. The Unified Modeling Language (UML) diagram in Figure 4.1 illustrates the relationships among geographic entities involved in the project. 


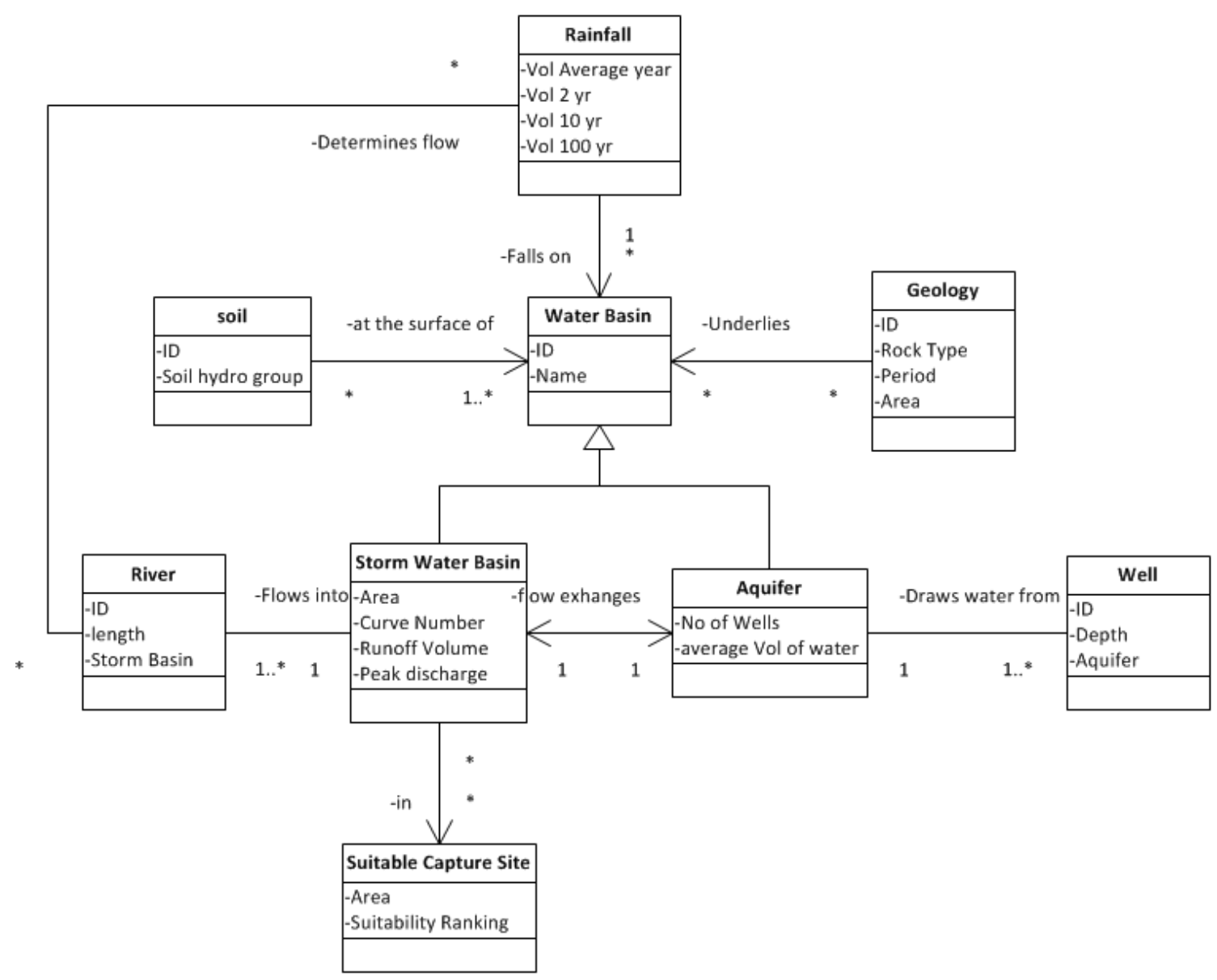

Figure 4.1: Conceptual model

\subsection{Logical Data Model}

The logical model transformed the conceptual model into a physical database. The Esri file geodatabase was adopted. Advantages of the Esri file geodatabase include its ability to organize data into similar themes, large storage capacity, and existing data models which could be modified to fit this project. The implemented geodatabase was a modification of the Esri Arc Hydro data model. Additional feature classes and feature datasets were added to the default Arc Hydro Data model.

The conversion of the conceptual model to a logical implementation model was not a straightforward process. The suitability analysis for identifying candidate water capture sites required raster datasets therefore the required inputs and results were stored in a file folder. Water basins and streams were grouped together within the Layers dataset created automatically by Arc Hydro. Three storm water basin classes were created to represent different size aggregation levels of basin extent. Other non-conceptual feature classes that were required to delineate and process basin parameters were also added to this class.

The most important addition to the storm water basin attribute was rain. In implementing the database, the rain entity became an attribute of the storm water basins in the form of mean basin rainfall. Five rain attributes were added in this way to 
represent rainfall events with different reoccurrence periods. Multiple runoff volume and peak discharge attributes were added to hold the values for different rain events. Some Arc Hydro data model feature classes also became part of the database. GIS datasets for aquifers were not available, so they were not included in the logical model implementation. The Runoff results were stored in a second feature dataset. The diagram in Figure 4.2 shows the schema of the logical model.

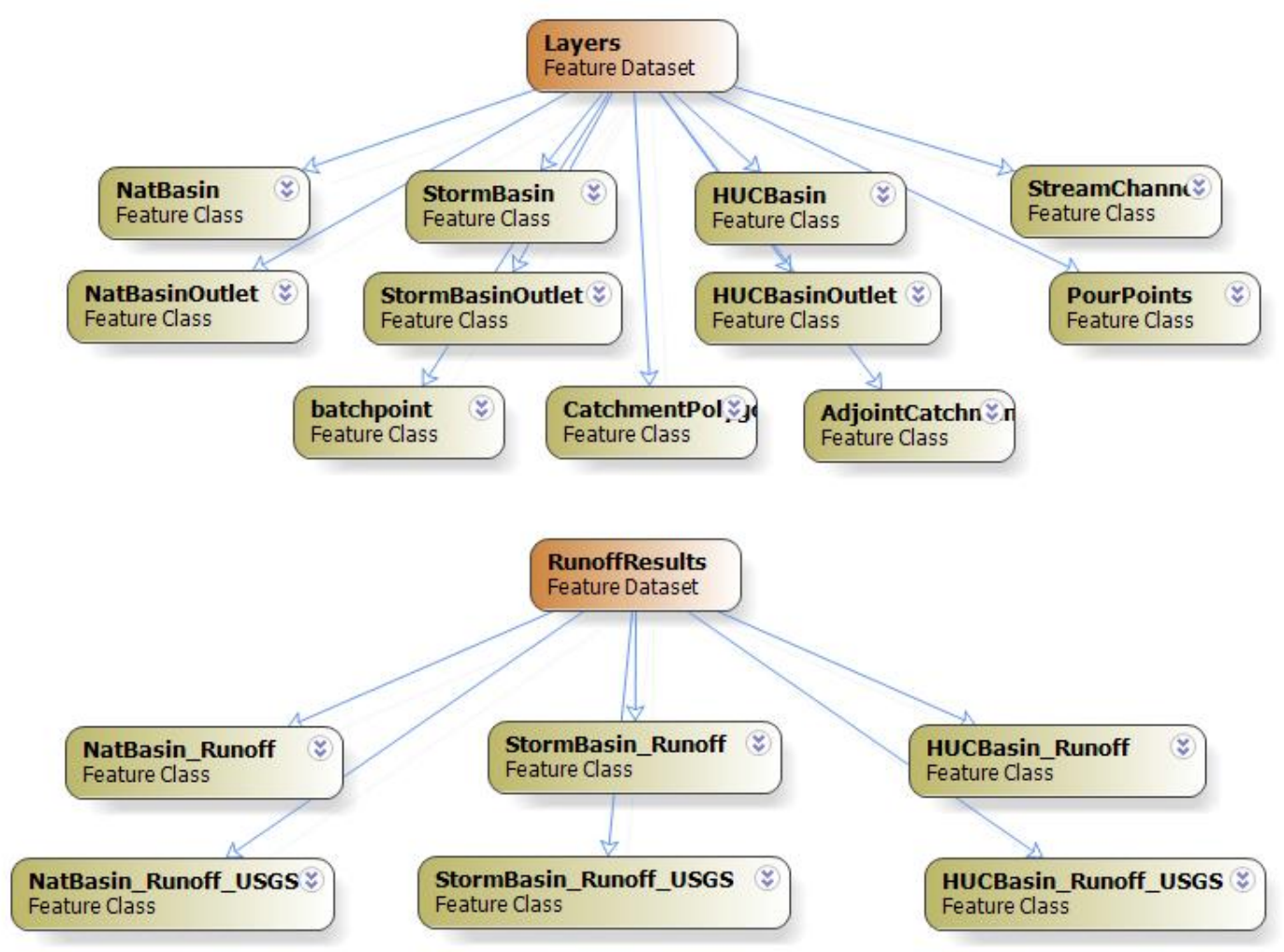

\section{Figure 4.2: Logical model}

\subsection{Data Sources}

Data for the project were collected from several sources. Elevation, land cover, hydrography, and soil datasets were downloaded from the Natural Resource Conservation Services (NRCS) geospatial data gateway. Some of the data downloaded from the data gateway were not produced by the NRCS but were available for download as part of efforts to make government data accessible from a central source. The annual average precipitation dataset was downloaded from the Parameter-Elevation Regressions on Independent Slopes Model (PRISM) website. Rain frequency datasets were downloaded from the precipitation frequency estimate service of the National Oceanic and Atmospheric Administration (NOAA). The Mojave Desert Ecosystem Program (MDEP) provided geology data for Fort Irwin. Table 3 lists the datasets, their format, sources, and metadata status. 
Table 3. Data sources

\begin{tabular}{|l|l|l|l|}
\hline Data & Format & Source & Metadata \\
\hline $\begin{array}{l}\text { 10m Digital Elevation } \\
\text { Model }\end{array}$ & Raster & $\begin{array}{l}\text { Natural Resource Conservation } \\
\text { Services, U.S Dept. of Agriculture }\end{array}$ & Included \\
\hline Land Cover & Raster & U.S. Geological Survey & Included \\
\hline $\begin{array}{l}\text { National Hydrography } \\
\text { Dataset }\end{array}$ & Shapefile & $\begin{array}{l}\text { U.S. Geological Survey in } \\
\text { cooperation with U.S. Environmental } \\
\text { Protection Agency }\end{array}$ & Included \\
\hline $\begin{array}{l}\text { Precipitation } \\
\text { Frequency Estimates }\end{array}$ & Raster & $\begin{array}{l}\text { National Oceanic and Atmospheric } \\
\text { Administration }\end{array}$ & Included \\
\hline $\begin{array}{l}\text { Average Annual } \\
\text { Precipitation }\end{array}$ & Raster & $\begin{array}{l}\text { PRISM climate group, Oregon State } \\
\text { University, Oregon }\end{array}$ & Included \\
\hline $\begin{array}{l}\text { Soil (SSURGO and } \\
\text { STATSGO data) }\end{array}$ & $\begin{array}{l}\text { Microsoft } \\
\text { Access } \\
\text { personal } \\
\text { database, } \\
\text { Esri layer } \\
\text { Package }\end{array}$ & $\begin{array}{l}\text { Natural Resource Conservation } \\
\text { Services, U.S. Dept. of Agriculture }\end{array}$ & Included \\
\hline Geology & Shapefile & $\begin{array}{l}\text { Mojave Desert Ecosystem Program, } \\
\text { U.S. Dept. of Defense }\end{array}$ & Not Included \\
\hline
\end{tabular}

\subsection{Data Scrubbing and Loading}

Original datasets had a larger spatial extent than the study area and came in different projections. Therefore, all datasets had to be projected and clipped to the study area extent. Some of the datasets, however, required extra preprocessing before becoming suitable for use in the project. Tools were created to automate preprocessing wherever possible. An intermediate geodatabase was also created to handle the results of all preprocessing.

\subsubsection{Elevation Data Preprocessing}

The elevation data (DEM) had a 10 meter spatial resolution. The dataset was available as 7.5 minute by 7.5 minute quadrangles for the entire United States. Several quadrangles were needed to cover the study area. To make the data suitable for analysis, the quadrangles were mosaicked using the create raster dataset function in ArcGIS. To reduce processing time during implementation, the mosaicked DEM data type was converted to integer data using an expression in the ArcGIS raster calculator. In addition, to ensure the new data retained most of the precision of the old data, an expression that multiplies the actual values by a factor of 10 was used. This action reduced the DEM height ( $\mathrm{z}$ unit) unit by a factor of 10. The height factor was then manually adjusted within the integer raster's projection file to reflect the change in height unit. 


\subsubsection{Soil Data Preprocessing}

Soil data were downloaded from the Soil Survey Geographic Database (SSURGO) as proprietary tables. The ArcMap soil data viewer and an empty Microsoft access database template were also downloaded. The spatial component of the soil data was a shapefile with a key field which could be used to join tabular soil data. The empty personal database was populated with data from the SSURGO tables using a series of steps recommended by the NRCS.

The ArcMap soil data viewer was installed as a new tool in ArcGIS desktop. The tool's interface is shown in Figure 4.3. Using this tool, it was possible to interactively query the soil database and link query results to fields in the shapefile using the key field. The soil attribute required for this study was the Hydrologic soil group. It was therefore selected under the soil qualities and features folder and this brought up a selection of mapping units under the report options tab. Clicking the map button at the bottom of the soil data viewer interface initiated a query of hydrologic soil attributes for all mapping units in the database. The query resulted in a temporary joining of the hydrologic soil group attribute to the soil shapefile. The joined attributes were exported into a new shapefile to make the joined attributes a permanent part of the soil feature class table.

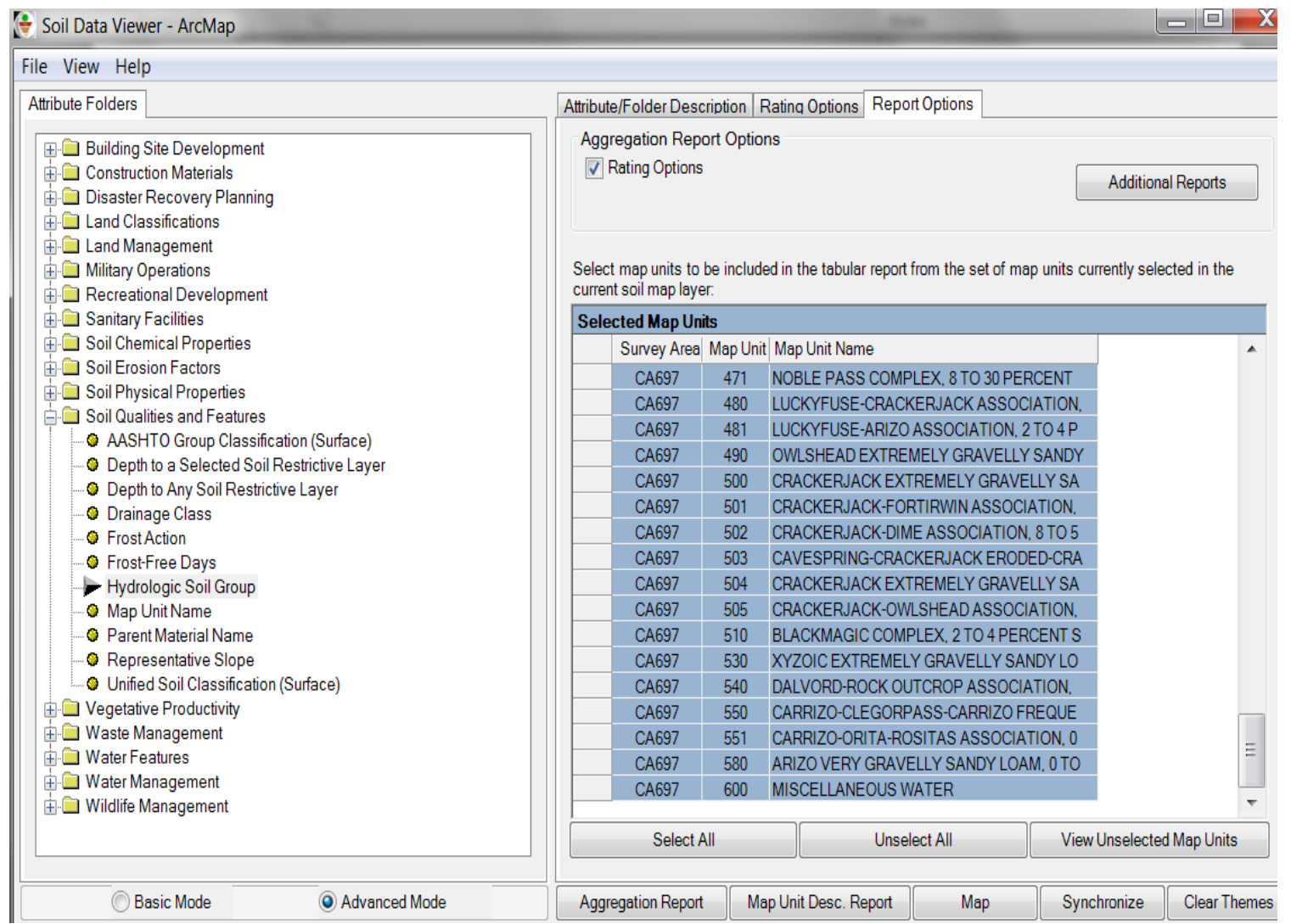

Figure 4.3: User interface of the SSURGO soil data viewer for Arcmap

A few features with no data were noticed in the data attribute table of the new soil shapefile. Parts of the study area outside Fort Irwin were also missing as the SSURGO data for these areas had not yet been published. An online search revealed that a 
statewide generalized soil dataset called States Soil Geographic Database 2 (STATSGO 2), with hydrologic soil group data, was available as an Esri layer package. The

STATSGO 2 dataset was downloaded and used to fill in attributes with a null value. It was also used to add data for parts of the study area that were not included in the SSURGO data. The final soil data shapefile was then imported into the intermediate project geodatabase. The maps in Figure 4.4 illustrate the process of using STATSGO data to fill in areas with no data.
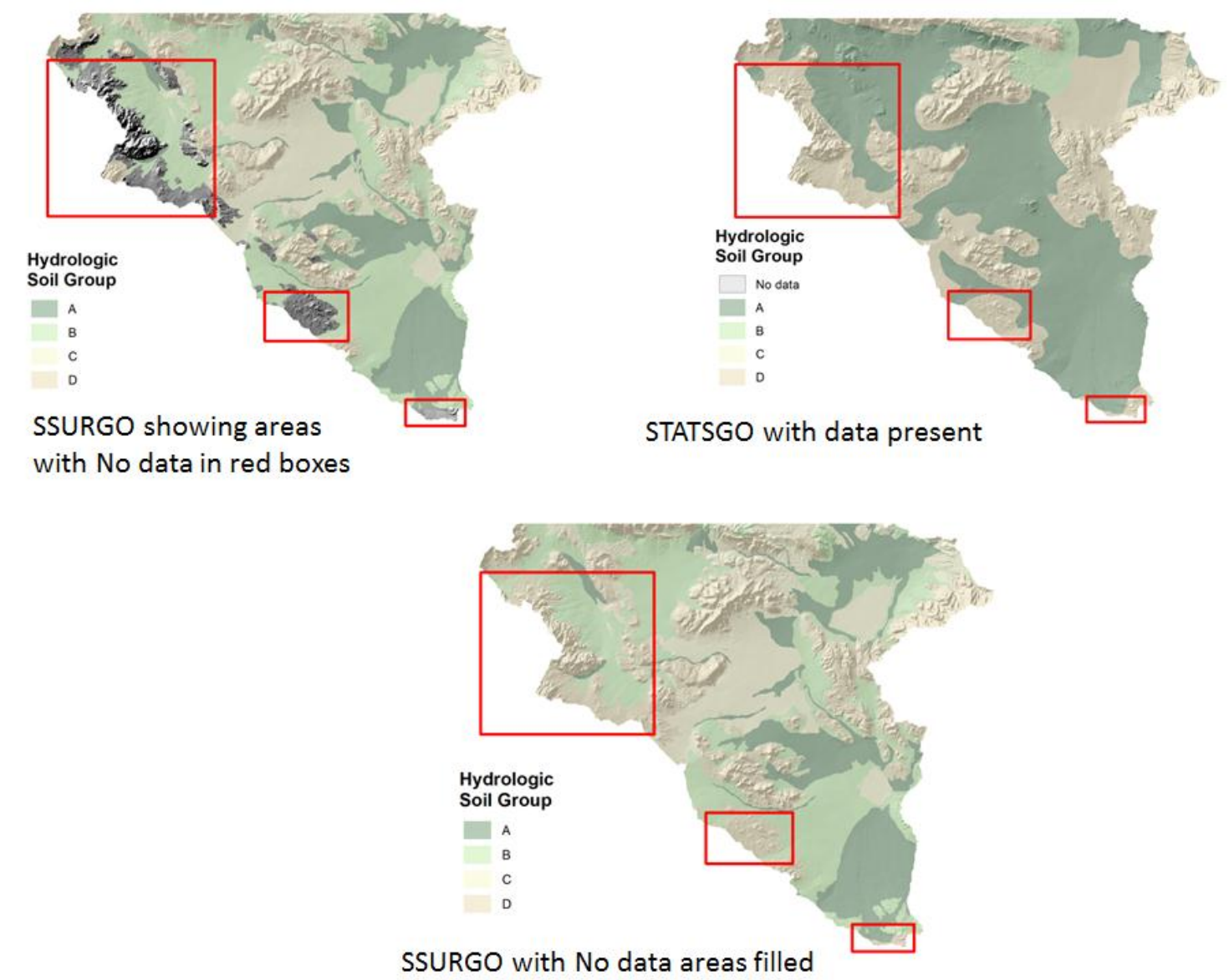

Figure 4.4: Using STATSGO data to fill in areas with no data

\subsubsection{Land Cover Data Preprocessing}

The land cover data were in raster format. All pixels representing the same land cover class were assigned the same digital number value. The metadata provided information about how the land cover data were classified. The raster was converted to a polygon vector and reclassified to ensure the new classes conformed to the land cover classification scheme created by the NRCS for use with the Curve Number method of estimating runoff. The Curve Number is a runoff/infiltration coefficient value assigned based on differences in land cover and soil type. Assigned values can range from 30 (woods with well drained soils) to 98 (impervious surfaces like asphalt). Look up tables matching land cover-soil type combinations to Curve Number values are available from 
the NRCS. A look up table for the study area was created in ArcGIS and is shown in Figure 4.5.

\begin{tabular}{|c|c|c|c|c|c|}
\hline & OBJECTID * & LandUse & Soil & LCSOIL & CurveNumber \\
\hline & 5 & Developed Mid Density & A & Developed Mid DensityA & 61 \\
\hline & 6 & Developed Mid Density & $\mathrm{B}$ & Developed Mid DensityB & 75 \\
\hline & 7 & Developed Mid Density & C & Developed Mid DensityC & 83 \\
\hline & 8 & Developed Mid Density & D & Developed Mid DensityD & 87 \\
\hline & 9 & Developed High Density & A & Developed High DensityA & 77 \\
\hline & 10 & Developed High Density & $B$ & Developed High DensityB & 85 \\
\hline & 11 & Developed High Density & C & Developed High DensityC & 90 \\
\hline & 12 & Developed High Density & D & Developed High DensityD & 92 \\
\hline & 13 & Desert Shrub Poor & A & Desert Shrub PoorA & 63 \\
\hline & 14 & Desert Shrub Poor & $B$ & Desert Shrub PoorB & 77 \\
\hline & 15 & Desert Shrub Poor & C & Desert Shrub PoorC & 85 \\
\hline & 16 & Desert Shrub Poor & D & Desert Shrub PoorD & 88 \\
\hline & 17 & Grassed Open Space & A & Grassed Open SpaceA & 39 \\
\hline & 18 & Grassed Open Space & $\mathrm{B}$ & Grassed Open SpaceB & 61 \\
\hline & 19 & Grassed Open Space & C & Grassed Open SpaceC & 74 \\
\hline & 20 & Grassed Open Space & D & Grassed Open SpaceD & 80 \\
\hline & 21 & Desert Shrub Fair & A & Desert Shrub FairA & 55 \\
\hline & 22 & Desert Shrub Fair & B & Desert Shrub FairB & 72 \\
\hline & 23 & Desert Shrub Fair & $\mathrm{C}$ & Desert Shrub FairC & 81 \\
\hline & 24 & Desert Shrub Fair & $\mathrm{D}$ & Desert Shrub FairD & 86 \\
\hline & 25 & Impervious Area & A & Impervious AreaA & 98 \\
\hline & 26 & Impervious Area & B & Impervious AreaB & 98 \\
\hline & 27 & Impervious Area & $\mathrm{C}$ & Impervious AreaC & 98 \\
\hline & 28 & Impervious Area & D & Impervious AreaD & 98 \\
\hline
\end{tabular}

\section{Figure 4.5: Curve Number lookup table}

\subsubsection{Rainfall Data Processing}

Rainfall datasets were downloaded from two different sources, the PRISM data site and the NOAA National Weather Service web site. Average annual rainfall for the 1970 2000 period was downloaded from the PRISM website. Precipitation estimates for a 24 hour rain event with likely recurrence periods of 1, 2, 10 and 100 years were downloaded from NOAA. All original rainfall data were in ASCII file format which necessitated conversion to a raster grid. The PRISM grid was in the WGS 1972 Geographic coordinate system while the NOAA precipitation grids were in NAD 83 UTM Zone 11. The datasets were re-projected to WGS 84 UTM Zone 11 and clipped to the extent of the $10 \mathrm{~m}$ DEM using the Model Builder workflow shown in Figure 4.6. 


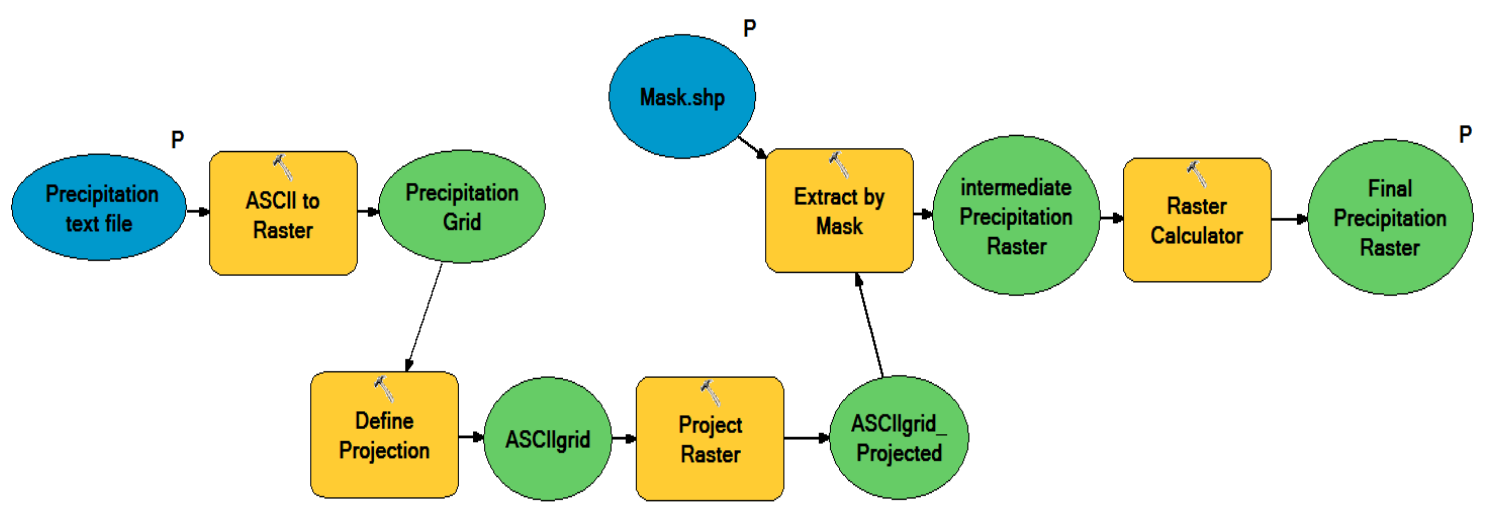

Figure 4.6: Precipitation data conversion and projection model

\subsection{Summary}

The conceptual model presented in this chapter depicted the fundamental relationships among the entities involved in this study. The modeled relationships were transformed into a physical database using a logical model implemented with a geodatabase. The data sources and data preprocessing techniques were discussed. The extra effort required to process elevation, land cover, soil, and rainfall datasets was noted. Additionally the GIS workflows that facilitated the preprocessing of these datasets were elaborated. 


\section{Chapter 5 - Implementation}

Workflows and mathematical formulas are required in delineating basins, calculating runoff parameters, as well as in carrying out suitability analysis for water capture. Some of these workflows are relatively simple, but tedious to carry out using traditional techniques. This chapter presents the GIS methods used to create tools that met the functional requirements of the project. The methods are discussed under three headings, including basin preprocessing and delineation, basin attributes and runoff calculations, and suitability analysis.

\subsection{Basin Preprocessing and Delineation}

Water basin delineation in GIS requires several preprocessing steps to generate preliminary datasets. Arc Hydro has tools and models that are designed for basin preprocessing which were adopted for this study. The adopted procedures are discussed below.

\subsubsection{Basin Preprocessing}

The main dataset required for modeling basin boundary and water flow in a GIS is a Digital Elevation Model (DEM). The Arc Hydro toolset has prebuilt models for deriving flow characteristics from a DEM. None of the default models were however, able to adequately represent the study area. Additional workflows and changes to standard models were made before a suitable representation was achieved. Basin preprocessing also helped to identify the boundary of the study area. This was important because all analysis had to be limited to the extent of the drainage basins. Figure 5.1 illustrates the basin preprocessing workflow. 


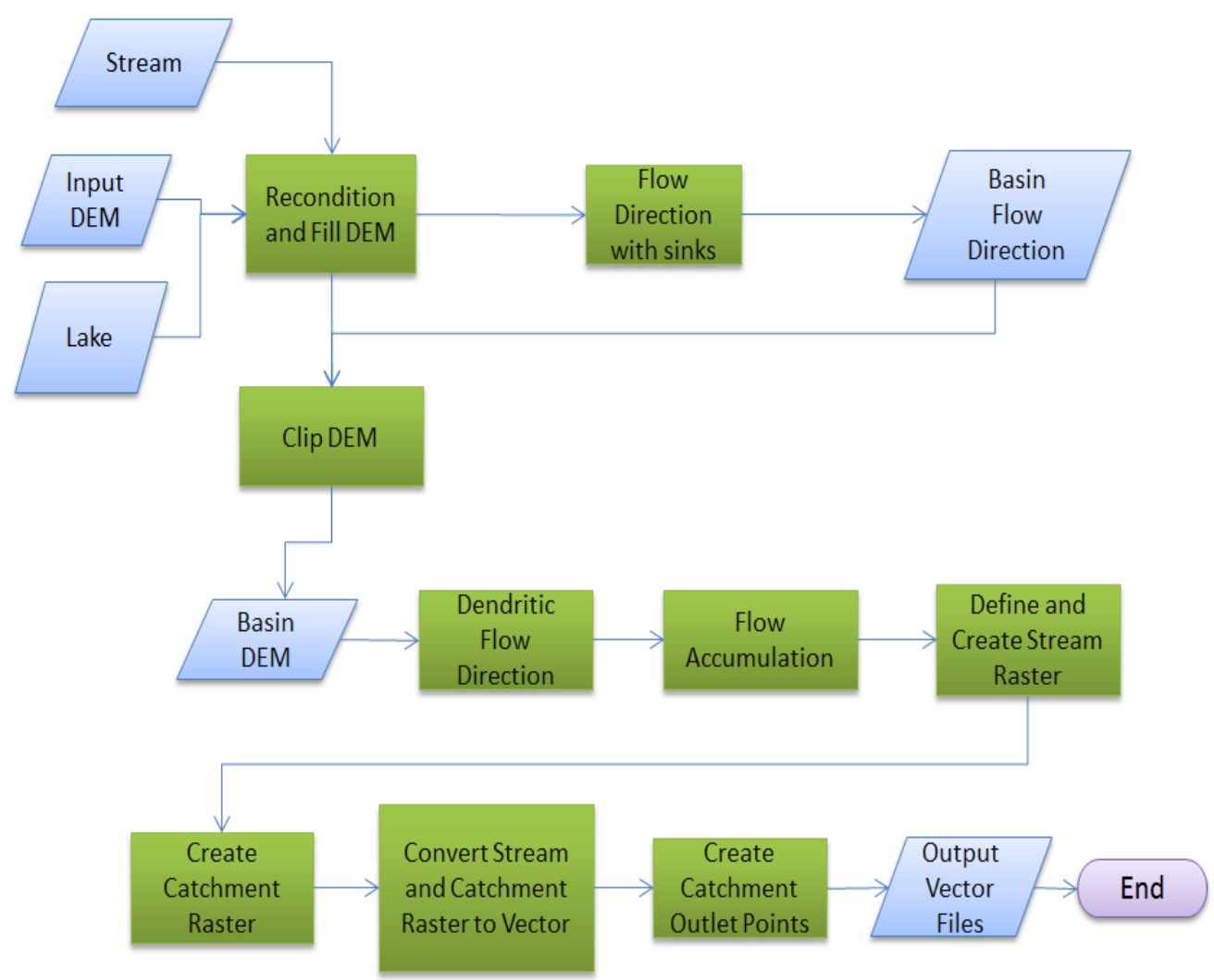

Figure 5.1: Basin preprocessing workflow

The study area is a closed drainage basin with all surface water flowing into two dry lake beds. After several iterations, a hybrid of the standard Arc Hydro models for closed basin and open basin (dendritic) preprocessing was developed. To get the hybrid model to work, the size of the input DEM had to be reduced to a size just slightly larger than the study area. This was necessary because the closed basin DEM workflow combined all closed basins into one large basin even if the streams flowed to different internal drainage sinks. An additional workflow was included for reconditioning the DEM to enable correct stream identification, as the initial stream channels derived from the model did not match the reality. The reconditioning process imposed stream channels on the DEM by lowering the elevation values within the stream channel. After reconditioning, the DEM had to be filled to remove pits, which would have otherwise impeded water flow modeling. Pits which are also known as sinks do not have water flowing out of them as they have lower elevation values than the surrounding cells. Reconditioning and DEM filling required a stream feature class and true flow sinks (lakes) that accurately represented the reality. Stream and lake data used for reconditioning and filling were downloaded from the national hydrologic dataset.

A flow direction grid which represented the direction of steepest elevation descent for each cell was created using the Flow Direction with Sinks tool. This tool also allowed the derivation of the closed basin boundary, which was then used to reduce the filled DEM to the same extent as the study area before further processing. A flow accumulation 
raster that contained information about the number of upstream cells contributing flow to each cell was then derived.

A second set of flow accumulation and flow direction grids were derived using a dendritic preprocessing workflow. These new raster grids were required because the closed basin preprocessing workflow did not allow for the delineation of sub basins and streams. The dendritic flow direction and flow accumulation grids served as inputs to the stream definition and stream grid creation process. Stream channels were derived by setting a minimum flow accumulation value of 5000. Cells that met this condition were given a value of 1 , while other cells were given a null value in the resultant stream grid. Using the stream grid in combination with the dendritic flow direction and flow accumulation grids, it was possible to extract stream lines, catchment polygons, and outlet points for catchment polygons. For each catchment, a polygon representing the upstream area draining to its inlet point was also extracted and stored in an adjoint catchment feature class. This feature class was later used to speed up the basin delineation process.

\subsubsection{Basin Delineation}

Datasets derived from the basin preprocessing model served as inputs for basin delineation while the Arc Hydro tools were adopted for interactive batch delineation. In addition to being present on the toolbar, the Arc Hydro basin delineation tool also existed as a model within a toolbox. The interactive basin delineation tool was used to determine the upstream area above each pour point. A pour point is a user specified input point for which a basin is delineated by identifying all of its flow contributing cells. Pour points for this study consisted of tributary stream outlets and the center of the two lakes into which all surface water in the study area flow. After the selection of each pour point, the delineation tool required a name and description for the expected output basin. A snap tolerance was used to ensure the pour points coincided with high value cells along the input stream grid. Other inputs required for basin delineation included the flow direction grid, the catchment polygon feature class, and the adjoint catchment polygon feature class. The basin delineation process outputs included the basins in the study area (Bicycle, Irwin, and Langford) and their outlets. An interactive basin delineation model that was able to perform the same function as the Arc Hydro tool was also created, using standard spatial analyst tools in case eventual users do not have access to Arc Hydro.

The Arc Hydro interactive sub basin tool was adopted for use in the delineation of sub basins within the study area. The tool required the same inputs as the basin delineation tool, but worked in a slightly different way. The sub basin delineation tool determined the area that contributed flow directly to each pour point, excluding any area that contributed flow to another sub basin. Delineated sub basins were non-overlapping subdivisions of the storm water basins. The interactive delineation workflow is illustrated in Figure 5.2. 


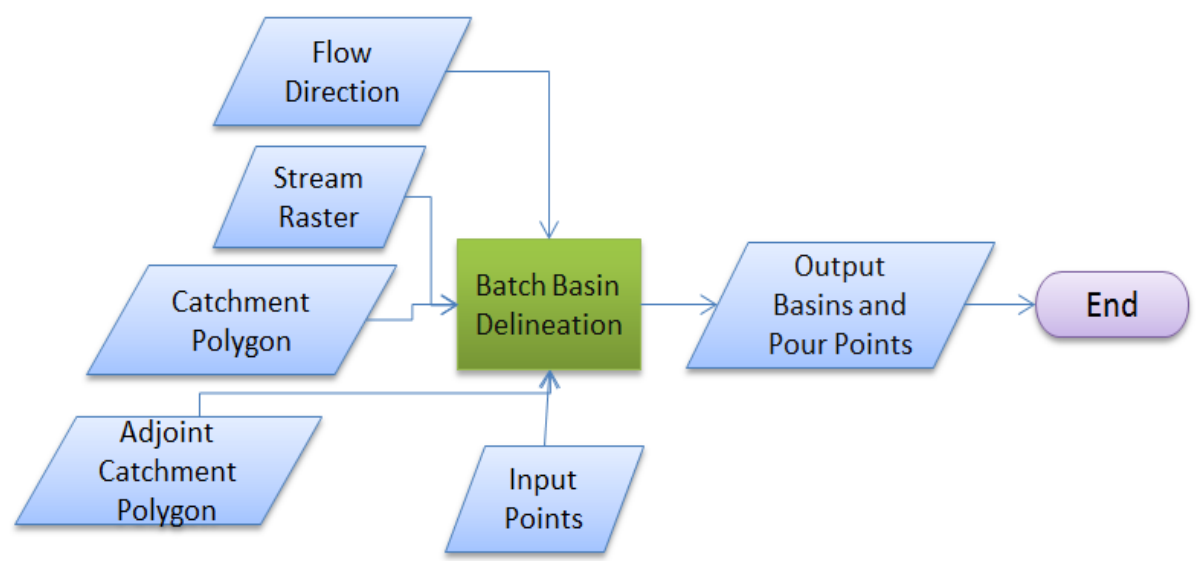

Figure 5.2: The basin delineation workflow

\subsection{Runoff Estimation Using the Curve Number Method}

Runoff includes water flowing in a stream as a result of rainfall (channel runoff), and flow in a basin that occurs when rainfall exceeds the soil infiltration rate (surface runoff). The Natural Resource Conservation Service (NRCS) Curve Number method was used to estimate runoff based on several basin attributes, including Curve Number, basin length, mean percent basin slope, and mean basin rainfall depth. A workflow for estimating runoff parameters was created using Model Builder. Individual model tools were created to calculate each of the required attributes. These models then served as intermediate tools in a new runoff calculation model. The detailed GIS workflows for generating basin attributes and formulas for estimating runoff with the Curve Number method are discussed in the subsections that follow. Figure 5.3 shows the workflow for the final runoff calculation model.

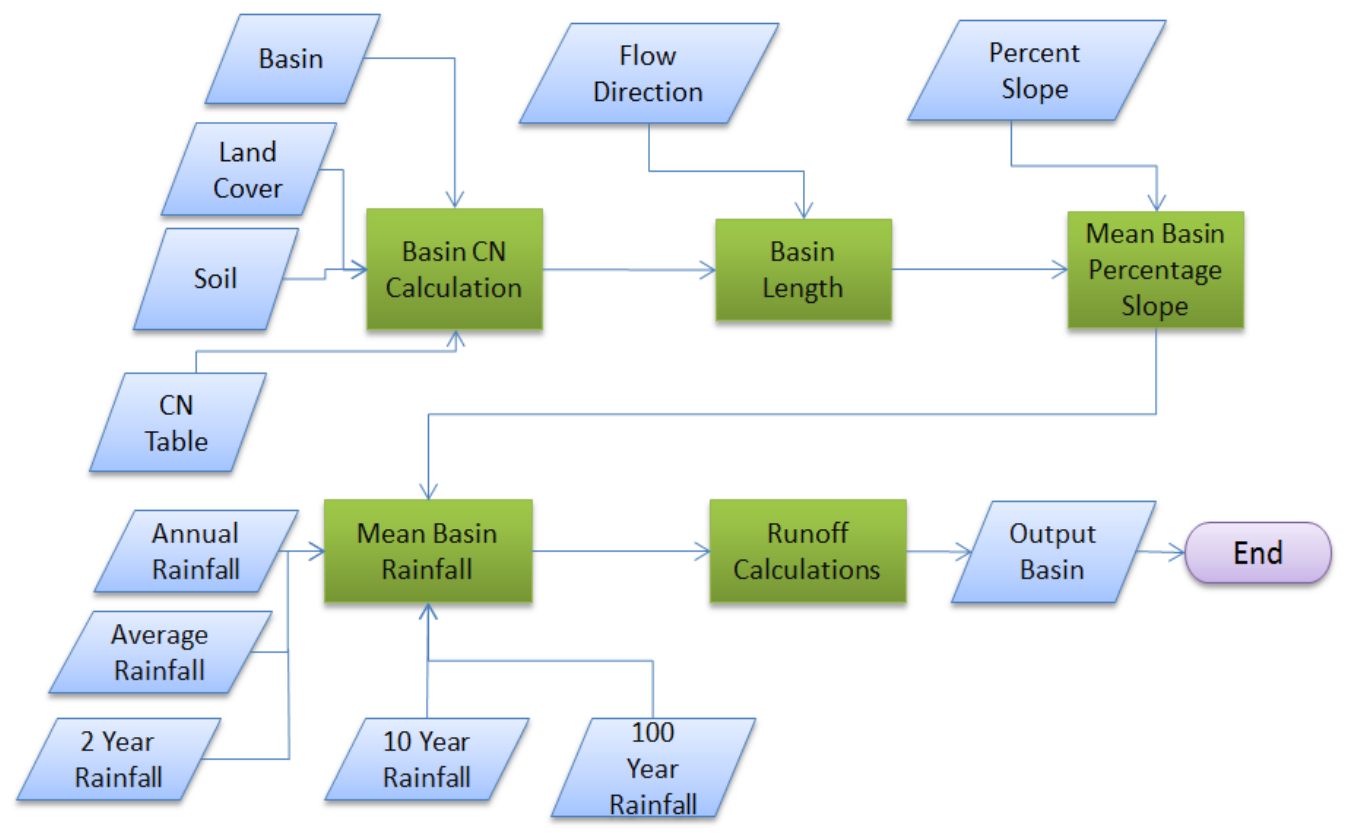

Figure 5.3: Curve Number method runoff estimation workflow 


\subsubsection{Mean Basin Curve Number Calculation Model}

The calculation of mean basin Curve Number values required four input datasets. These included the basins for which mean Curve Numbers were required, land cover, hydrologic soil group, and a Curve Number table. To successfully run the model, certain fields with specific names were required in each of the four input datasets. The basin data had to have a field called "Name" which served as the identity for individual basins. The land cover data had to have a field called "LandCover" which specified the different land cover types found in the study area. The soil data had to have a field called "HydrolGrp" which specified the soil hydrologic groups present in the study area. The Curve Number table had to have a field called "LCSOIL" which contained all possible land cover-soil hydrologic group combinations. The Curve Number table also had to contain a field called "CurveNumber" which contained the Curve Number for each land cover/hydrologic soil group combination. If any of the required fields were absent, the model would stop and give an error message. To ensure that future users had these fields in their datasets, a geodatabase schema with template feature classes was created. Any data imported into these template feature classes would inherit the required fields. The mean basin Curve Number calculation workflow is shown in Figure 5.4 below.

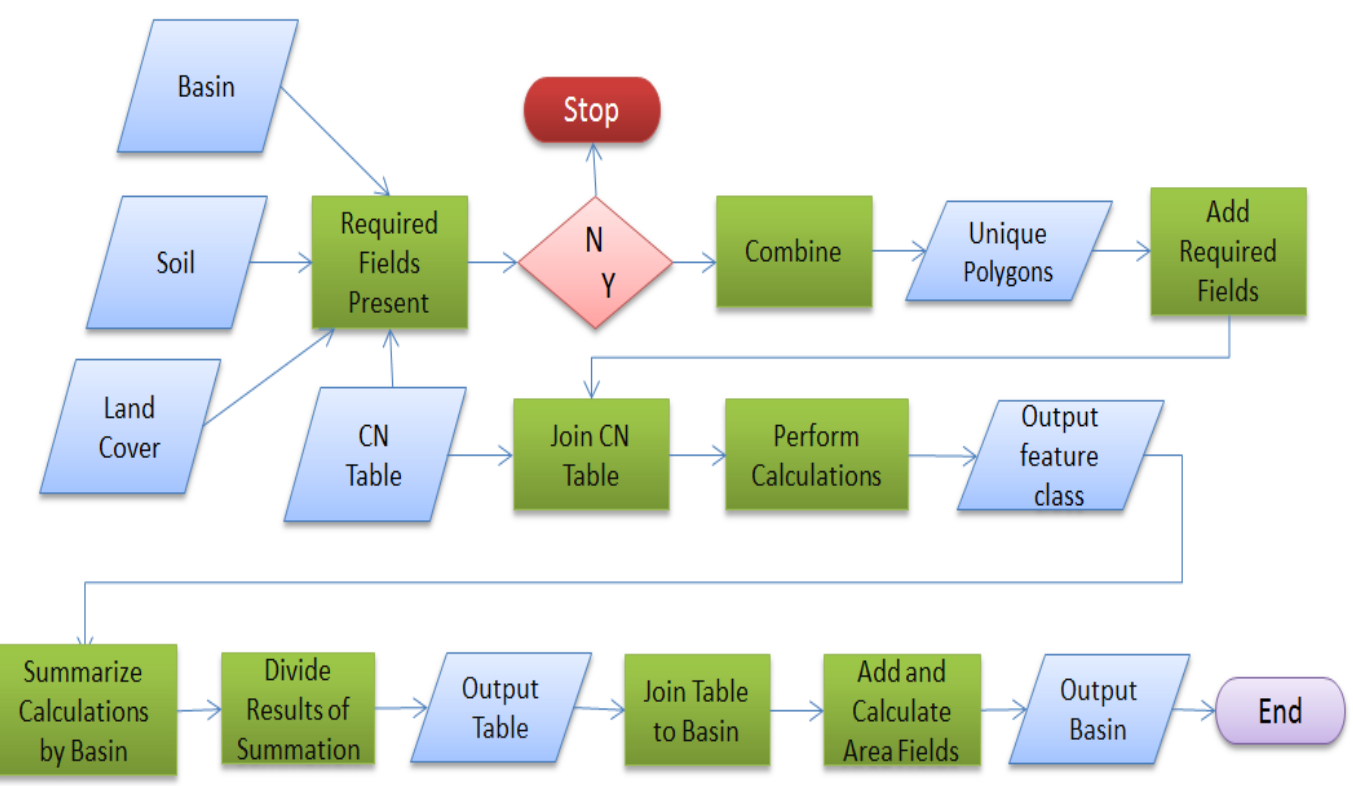

\section{Figure 5.4: Mean basin Curve Number calculation workflow}

The first step in the Curve Number calculation model was implemented using a script tool that tested the inputs for the required fields. If any of them were absent, the model would stop and give an appropriate error message. The land cover, soil, and basin datasets were combined using an intersection operation if all required fields were found. Next, a field was added to hold all possible land cover/hydrologic soil group combinations. The value for the field was determined by a query that joined the value in the "LandCover" and "HydrolGrp" fields into a single text block. This step was required so that the table with Curve Number values could be joined to the intersected dataset. The Curve Number table was then joined to the intersected dataset, based on common 
attributes in the intersected data and Curve Number table. The joined table provided Curve Number values for all land cover/soil combinations. Based on Curve Number values from the joined table, it became possible to calculate area-weighted Curve Numbers. A field was added to the intersected dataset for this purpose. To determine weighted Curve Numbers, each basin's area in square miles was multiplied by its Curve Number. The next step in the model summed up the weighted Curve Numbers for each basin. The summarized values were then stored in a summary statistics table.

The summary table was joined to a temporary feature layer that had the same data fields and values present in the original basin data. Next, a field was created to hold the mean basin Curve Number. The value for this field was determined by dividing each basin's weighted Curve Number by the total basin area. The final three steps in the workflow involved the addition and calculation of each basin's area in square feet, acres, and square miles.

\subsubsection{Basin Length Calculation}

The output from the basin Curve Number calculation model served as an input to the basin length calculation model. A flow direction grid was also required as an input. The distance from each cell in the flow direction grid to the basin outlet was calculated using the spatial analyst flow length tool. The cell values in the output from the calculation represented the length from each cell to the basin outlet. The length of each basin was determined by running a filter which extracted the maximum length value in each basin. The maximum length value was then joined to the input basins data. Next, the basin length was converted from meters to feet using a conversion factor of 3.28. The model workflow for calculating the basin length is shown in Figure 5.5.

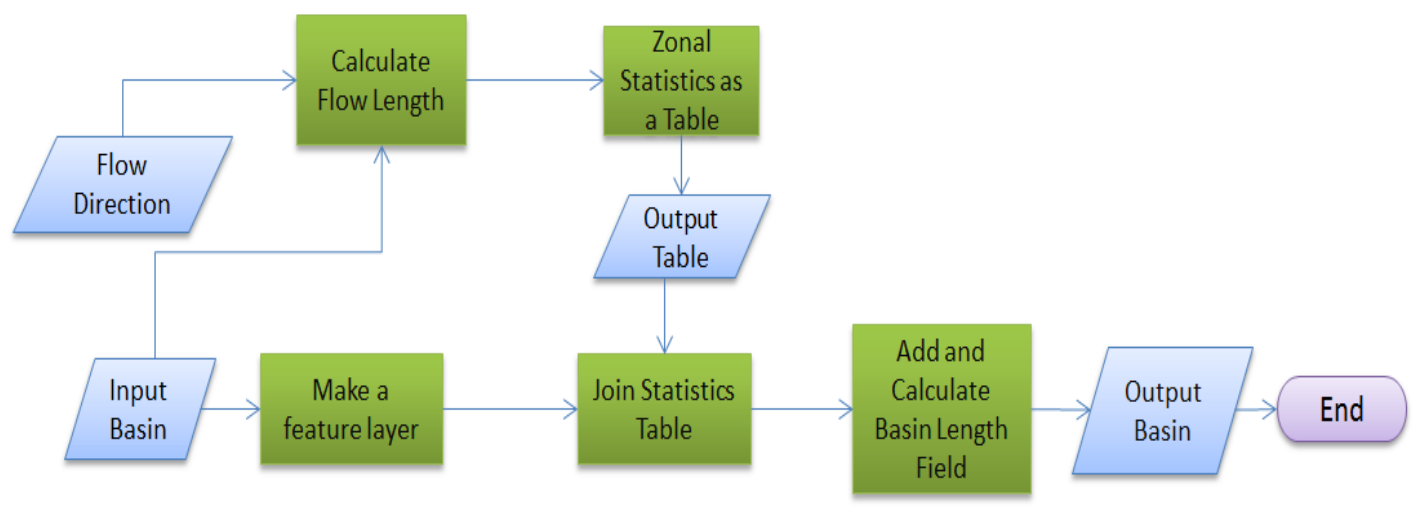

Figure 5.5: Basin length calculation workflow

\subsubsection{Mean Basin Slope Calculation}

Inputs to the mean slope calculation model were the output from the mean basin length model and a percentage land slope grid for the study area. The Zonal Statistics as a Table tool was used to run a filter that calculated the mean percent slope value for each basin. The output from this tool was then joined to the input basin feature class. The name of the mean percent slope field was ambiguous, so a new field called "mean slope" was 
created to store slope values. The model diagram in Figure 5.6 shows the workflow for mean basin percent slope calculation.

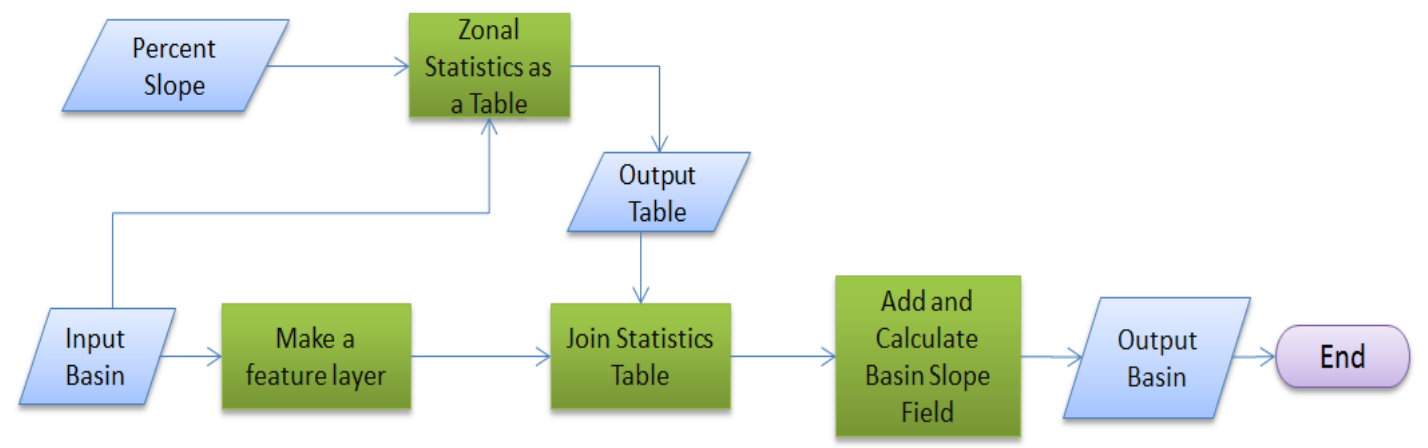

Figure 5.6: Mean Basin slope calculation workflow

\subsubsection{Mean Basin Rainfall Model}

To estimate runoff for rain storms with different return periods, a mean basin rainfall model was created. This model was used to calculate mean rainfall for five different rain events. The output from the mean basin percent slope model and five rain event grids served as inputs to the mean basin rainfall model. The zonal statistics as a table tool was used to run a filter that calculated the mean rainfall per basin for all five events. A field was then added to each zonal statistics table to hold the mean rainfall values. Four table join operations were performed to combine the five statistics tables together. The combined fields were then joined to the input basin data. Figure 5.7 shows the workflow of the mean basin rainfall calculation model.

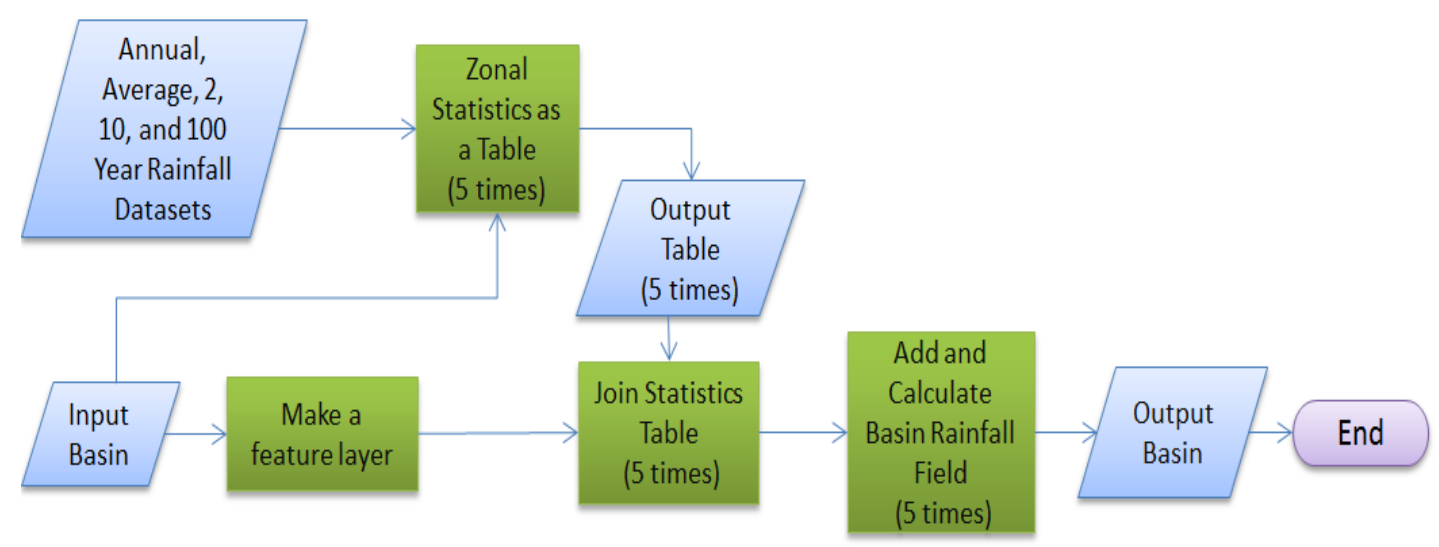

Figure 5.7: Mean basin rainfall calculation workflow

\subsubsection{Runoff Volume and Peak Discharge Calculation}

Once basin attributes had been calculated, several NRCS equations were used to determine each basin's runoff depth, peak discharge, and runoff volume. Two other parameters, potential maximum retention after runoff begins and Lag time, were required for runoff estimation. The lag time is the time interval between when rainfall intensity 
reaches a maximum to when peak discharge is achieved at the basin outlet. The two parameters were calculated from basin attributes. Potential maximum retention after runoff begins was calculated using equation 5-1.

Where:

$$
S=\frac{1000}{C N}-10
$$

$S$ - Potential maximum retention after runoff begins

$C N-$ Basin Curve Number

Lag time was calculated using equation 5-2.

Where:

$$
L T=\frac{l^{0.8}(S+1)^{0.7}}{\left(1900 * Y^{0.5}\right)}
$$

$L T$ - Lag time

$l$ - Length of drainage basin in feet

$Y$ - Average watershed land slope in percent.

Runoff depth refers to the height runoff from a rain event would attain if it was spread evenly over the surface of a basin. Equation 5-3 below was used to calculate runoff depth for each storm event.

Where:

$$
Q=\frac{(P-0.2 S)^{2}}{(P+0.8 S)}
$$

$Q-$ Runoff depth (inches)

$P$-Rainfall (inches)

$S$ - Potential maximum retention after runoff begins.

The equation for calculating peak discharge required the duration of the rain storm event. A field was added for this value and the duration of each storm event was entered into the field. The formula used for calculating peak discharge is shown in equation 5-4.

$$
Q p=\frac{484 A Q}{T p}
$$

Where:

$Q p$ - Peak rate of discharge (cubic feet per second [cfs])

484 - Constant applicable to triangular hydrograph peak discharge computed in cfs

$A-$ Basin area (square miles)

$Q-$ Runoff depth (inches)

Tp-Time to peak.

Time to peak is derived from equation 5-5.

$$
T p=\left(\frac{D}{2}\right)+L T
$$

Where:

$D$ - Duration of the storm (hours)

$L T$ - Lag time

The runoff volume is the total volume of water that becomes runoff during a rain event. Equation 5-6 below was used to calculate the runoff volume in acre foot per basin for each rain event.

$$
Q v=\frac{\left(\frac{Q * A a c}{12}\right)}{3.069}
$$


Where:

$Q v$ - Runoff volume (acre foot)

$Q-$ Runoff depth (inches)

$A_{a c}-$ Basin area (acres)

3.069 - Runoff volume conversion factor (acre foot to million Gallon)

Several fields were added to the runoff estimation model. The values for the fields were calculated using the formulas described above.

\subsection{Peak Discharge Estimation Using the USGS Method}

The United States Geological Survey (USGS) developed regression equations for estimating peak discharge from storm events. The equations developed for the southern great basin region 10 were applicable to the study area. The equations for maximum peak discharge for storms with 2,10, and 100 year reoccurrence periods were used for the study. The USGS peak discharge equations for the three storm return periods investigated are shown below.

Two year peak discharge:

$$
Q p=12 * A^{0.58}
$$

Ten year peak discharge:

$$
Q p=200 * A^{0.62}
$$

Hundred year peak discharge:

Where:

$$
Q p=590 * A^{0.67}
$$

$Q p$ - Peak discharge (cubic feet per second [cfs])

$A-$ Basin area (square miles)

The sole input to the USGS peak discharge estimation model was the basin feature class. The first step in the model checked if a field named "Area_Sqmi" which contained each basin's area in square miles existed. Whenever the field was found, the model then added three new fields to the input basin data to hold the 2 year, 10 year, and 100 year return period peak discharge. The values for these fields were calculated using the USGS regression equations above. If the "Area_Sqmi" field was not found in the input data, it was automatically created within the model. The workflow for the USGS peak discharge model is shown in Figure 5.8.

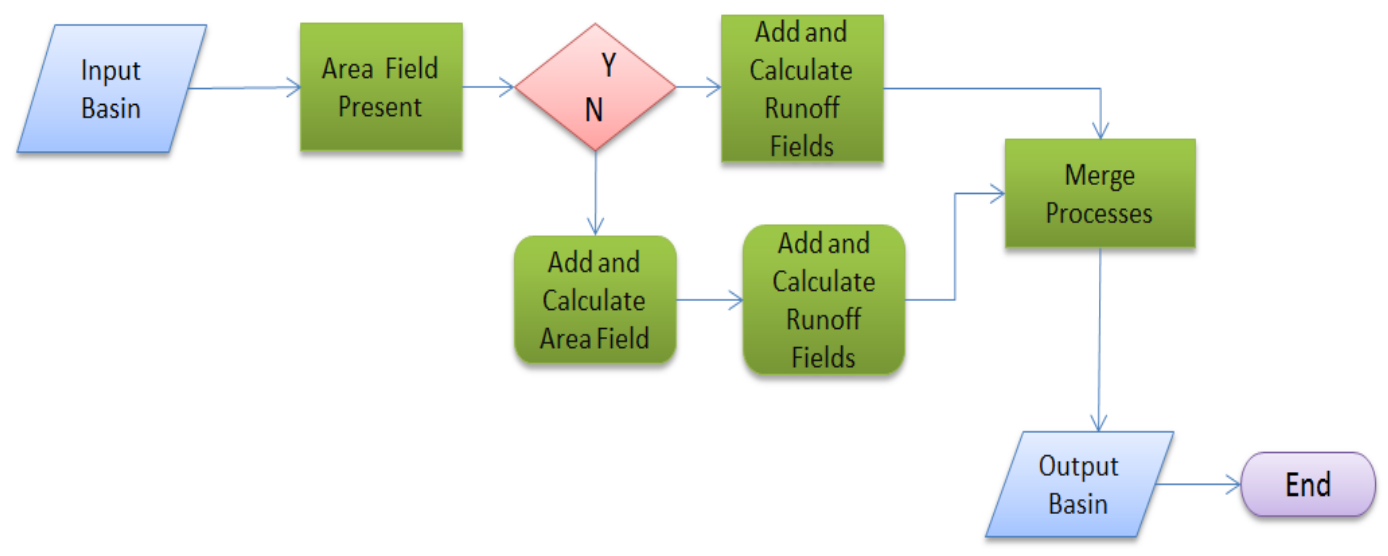

Figure 5.8: The USGS peak discharge estimation workflow 


\subsection{Suitability Analysis}

The study area was evaluated to determine sites that were suitable for storm water capture, by carrying out a weighted analysis of four factors using the ArcGIS weighted overlay tool. The factors considered were Curve Number, elevation, slope, and volume of runoff. The Curve Number was used because it is a measure of the rate of infiltration for land cover-soil hydrologic group combinations. The ArcGIS weighted overlay tool required classified raster inputs; therefore the dataset for each evaluated factor underwent some processing before suitability analysis was performed. A mask was also used to screen out built-up zones and areas with inappropriate geology. The workflows involved in developing the water capture suitability model are discussed in this section.

\subsubsection{Curve Number Factor}

Curve Number values for all land cover-soil type combinations were determined during the runoff estimation process. The polygon-to-raster tool was used to convert the Curve Number dataset to raster format. The rasterized dataset was then reclassified using the classification scheme shown in Figure 5.9. The classification scheme involved the use of Curve Number values as a measure of infiltration rates. The lowest Curve Number value (39) represents an infiltration rate greater than 0.3 inch per hour, while the highest value (98) represented no infiltration. The Curve Number 39 was assigned a score of 9 while the Curve Number 98 was assigned a score of 1 . The natural break classification scheme was used to assign values to Curve Numbers in between 39 and 98 . Using natural breaks ensured that deviation from the mean in each class was as low as possible.

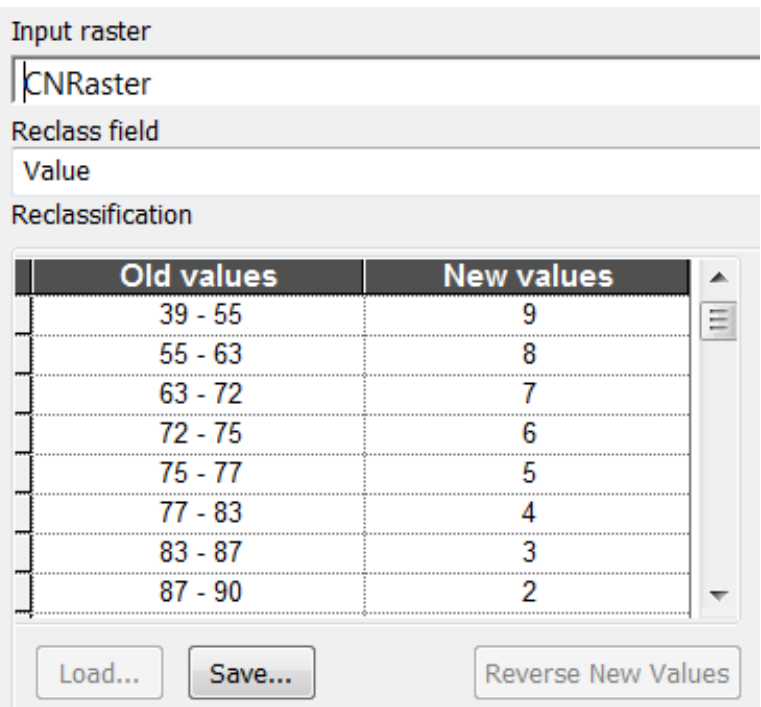

Figure 5.9: Curve Number reclassification dialog box 


\subsubsection{Elevation Factor}

Elevation analysis was limited to areas that were within 200 meters of river channels as distances beyond these were considered impractical for water capture. The Euclidean allocation tool was used to determine elevation cells that were no more than 200 meters from river channels. All cells that met this condition were then assigned the same value as the nearest stream cell. A mathematical expression was then used to subtract the allocated value of each cell from its value in the original elevation data. Cells with elevations lower than the river got negative values in the subtracted raster dataset, river cells got a value of 0 and areas that were higher than the river got a positive value. The derived elevation values were then reclassified using a reclassification scheme. All areas that were farther than 200 meters from streams were assigned a value of 1 . Areas within 200 meters of streams, but with higher than stream elevation, were assigned a value of 5 . Areas lower than the streams were assigned a value of 8 , while the stream channels themselves were assigned a value of 9 . The workflow used to derive the elevation factor is shown in Figure 5.10.

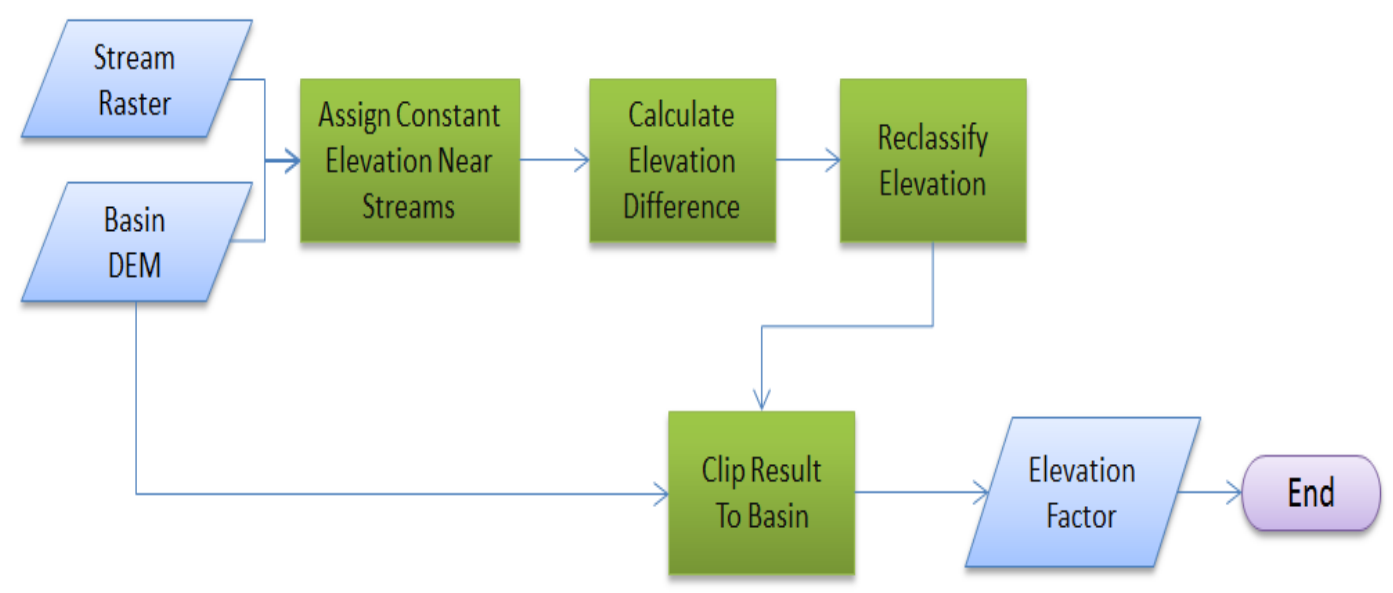

Figure 5.10: Elevation factor workflow

\subsubsection{Runoff Factor}

High runoff volume is by nature limited only to stream channels, as water aggregates in the stream channels. The flow accumulation raster derived during the basin delineation process was used for flow estimation. The values in this raster were equivalent to the depth of water that would flow in each cell if runoff attained a uniform depth of one inch across the basin. As was the case with the elevation factor, the euclidean allocation tool was used to assign the flow value of the nearest stream to all areas within 200 meters of stream channels. The raster calculation tool was then used to build an expression that reduced the flow value of each cell by a factor of one eighth (1/8) of its distance from the nearest stream. This essentially created a distance decay effect in the flow value of the cells. The raster calculator tool was used a second time to create an expression that added the original flow values for all cells not within 200 meters from streams. The last step in 
the workflow involved using the ArcGIS reclassify tool to categorize the runoff flow values into nine suitability classes using the natural breaks classification scheme. The workflow for the runoff volume factor is shown in Figure 5.11.

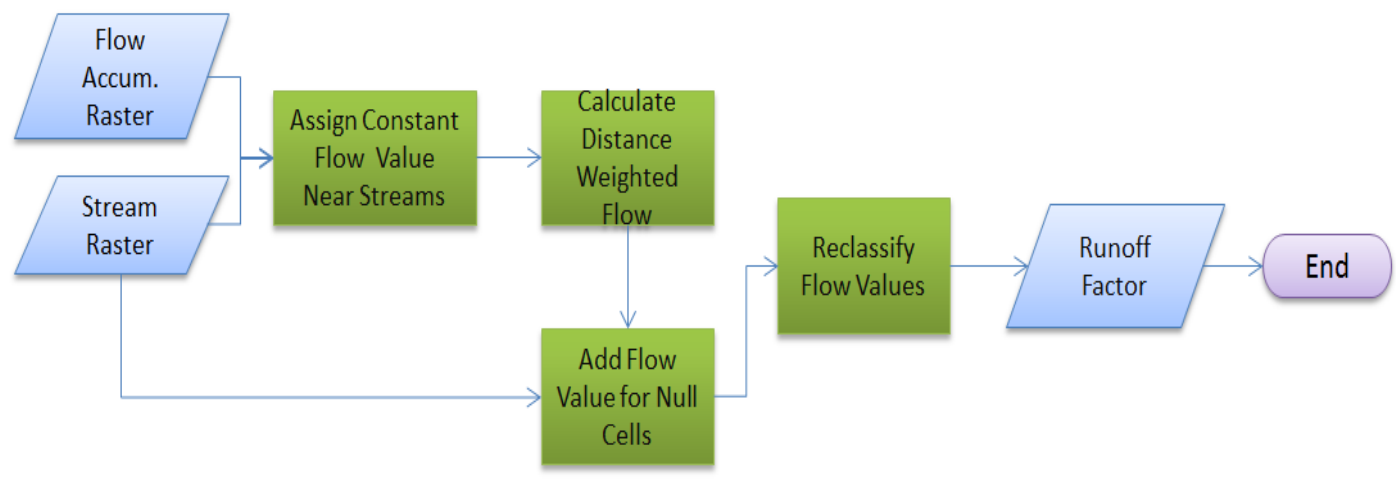

Figure 5.11: Runoff volume workflow

\subsubsection{Slope Factor}

The land slope raster was derived from the elevation grid. The ArcGIS percent slope tool was used to calculate the maximum rate of height change from each cell to its neighbors. The maximum height change value was divided by the distance between cells and multiplied by 100 to get percentage slope, which was then stored in a new raster. The reclassify tool was then used to clasify the slope values using the classification scheme shown in Figure 5.12.

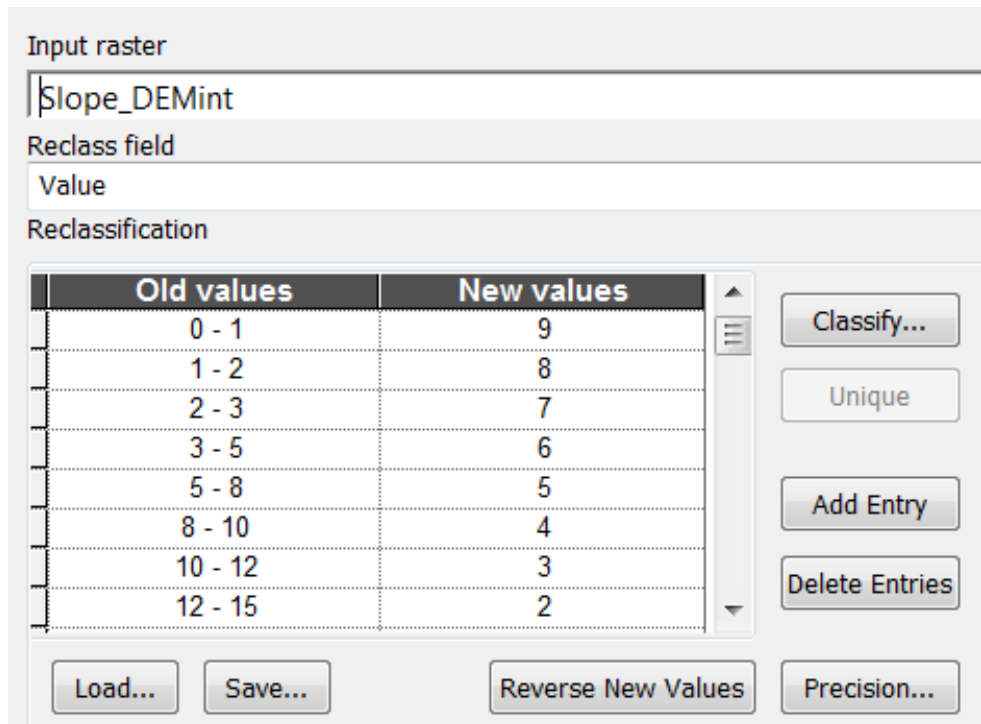

\section{Figure 5.12: Percent slope reclassification dialog box}

\subsubsection{Analysis Mask}

Certain parts of the study area were inappropriate for water capture. Areas in this category included all built-up within the base (residential areas, offices, parks and 
training facilities). These areas had a fixed land use that could not be changed. The lakes were also screened out because little or no infiltration occurs in the hardpan surface of the lake beds. One of the lake beds is used by the military as an aircraft landing strip. Areas underlain by igneous and metamorphic rocks were also screened out.

The first step in the mask preparation workflow was the selection of areas with inappropriate land cover and geology. These areas were then combined with the lakes dataset. An area extraction operation was used to create a feature class containing parts of the study area to be masked out of the analysis. A second area extraction operation was used to create another feature class containing areas where suitability analysis could be performed. An identifying value was calculated into an identity field in each of the two new feature classes to distinguish them. The masked areas and analysis extent were then combined using an ArcGIS tool. The output dataset from this operation was then rasterized in preparation for suitability analysis. Figure 5.13 shows the workflow for creating the analysis mask.

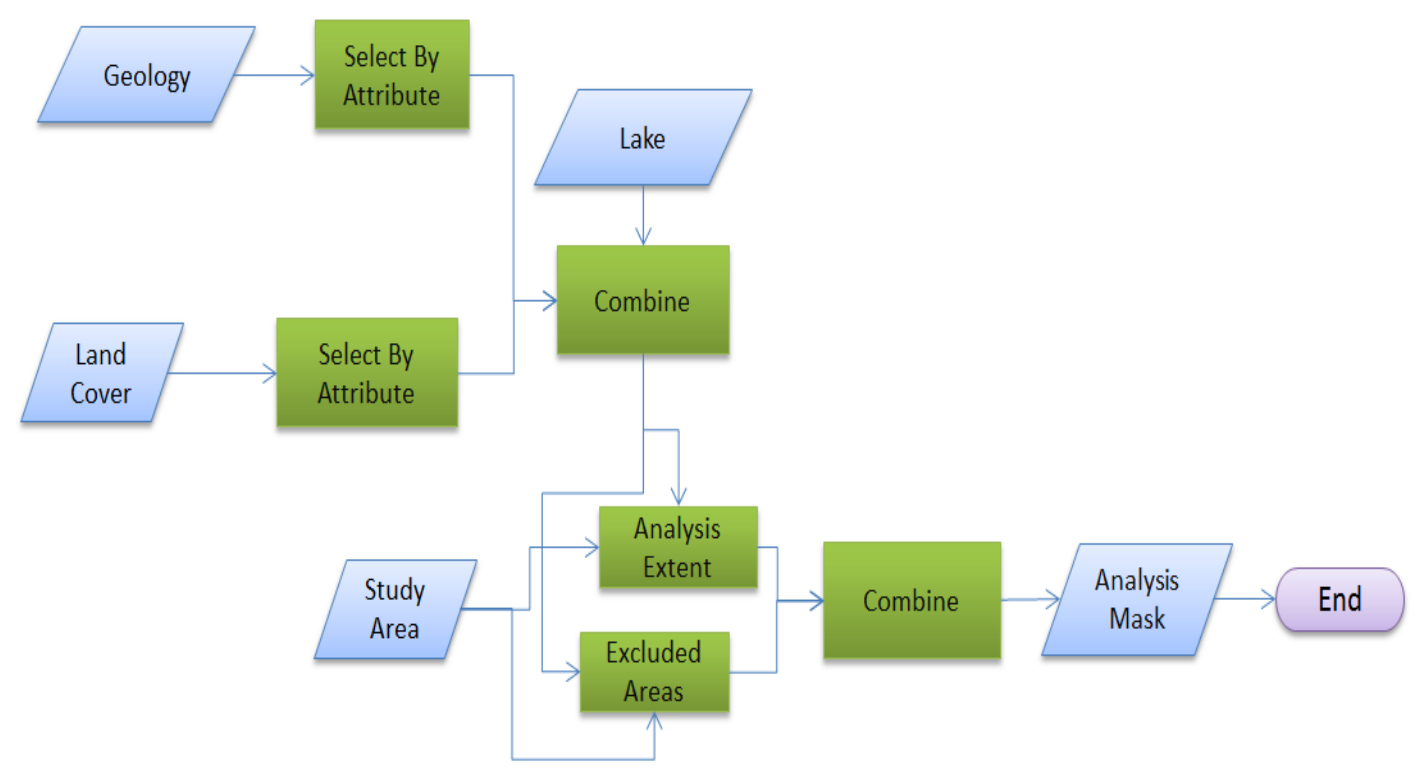

Figure 5.13: Analysis mask creation workflow

\subsubsection{Suitability Analysis}

After all inputs to the weighted analysis had been derived, a model was created to perform the suitability analysis and the classified raster datasets became part of a weighted overlay table. It was possible to change the relative weights of input factors, as well as the score of each value within the individual factors. The suitability analysis model was run several times with different weights assigned to each factor. After several iterations, ideal weights were determined for each factor. Runoff had a weight of $35 \%$, Curve Number and slope 25\% each, while elevation was given a weight of $15 \%$. These values were chosen because they represent the approximate mean of a small range around which the results essentially remained the same. The analysis mask was also included in the model. It had no weight but was used to screen out inappropriate parts of the study 
area from the analysis. Part of the weighted overlay table used for suitability analysis is shown in Figure 5.14.

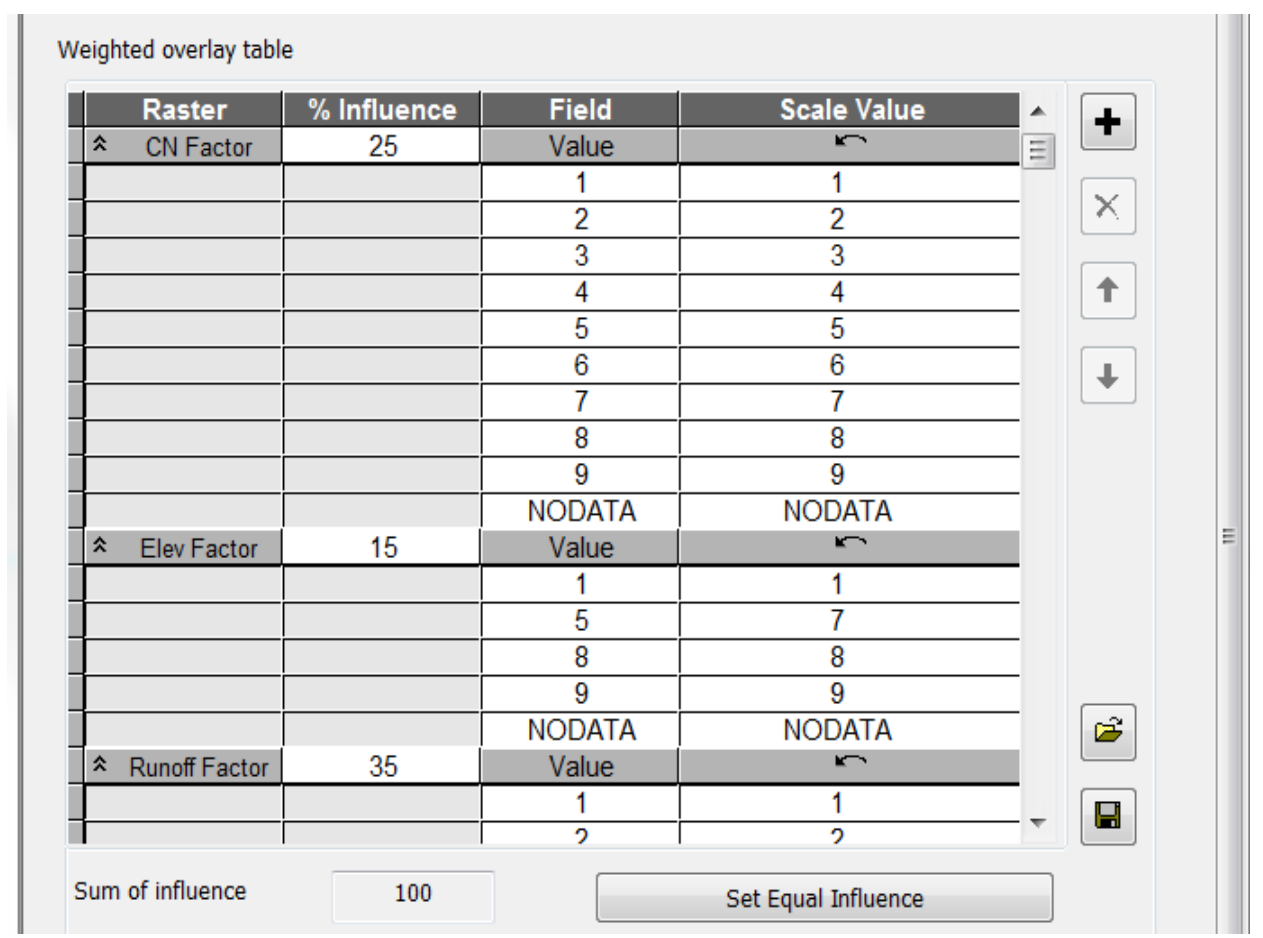

Figure 5.14: Suitability analysis weighted overlay table

\subsection{Summary}

The methodology for basin preprocessing and delineation, runoff estimation, and suitability analysis were discussed in this chapter. The basin preprocessing workflow was an adaptation of two standard Arc Hydro models. Basins and sub-basins were delineated using existing Arc Hydro tools. A basin delineation tool was also created using ArcGIS Spatial Analyst functions.

Runoff estimation for the study area involved creating a model to calculate runoff depth, peak discharge, and runoff volume using the NRCS Curve Number method. The USGS method was also incorporated into a model workflow to estimate peak discharge. A suitability analysis workflow which utilized the weighted overlay tool was used to help determine parts of the study area best suited for storm water capture. 


\section{Chapter 6 - Results and Analysis}

Data analysis and results from the GIS models created for the project are discussed in this chapter. Results from basin delineation based on different criteria are presented in the first section. This is followed by analysis of results from peak discharge and runoff volume calculations. The annual volume of water used on Fort Irwin is then compared with the runoff volume estimates to determine whether storm water collection would be a viable way for the base to achieve Net Zero Water Use. Candidate sites for water capture are also identified based on results from the weighted suitability analysis model.

\subsection{Basin Delineation Results}

The study area is located in the Mojave desert and drained by intermittent streams that contain water only after rain storm events. Three sets of basins were delineated for the study area, with each set based on a different criterion. These basins represented different levels of surface water basin aggregation. The first set of basins included the two natural drainage basins which empty into the Bicycle and Langford lakes. The other two sets of basins were subdivisions of the natural drainage basins. The first set of subdivisions made it possible to determine the area contributing runoff to the basin overlying each of the aquifers from which Fort Irwin draws water. The second set of sub divisions helped to evaluate the effect of aggregation on basin peak discharge estimates.

The streams in the study area flow into either of two dry lake beds (Bicycle and Langford lakes). As such, the study area is composed of two distinct closed drainage systems for which basins were delineated with the lake beds serving as natural outlets. The basins were named Bicycle Lake basin and Langford Lake basin, and are shown in Figure 6.1.

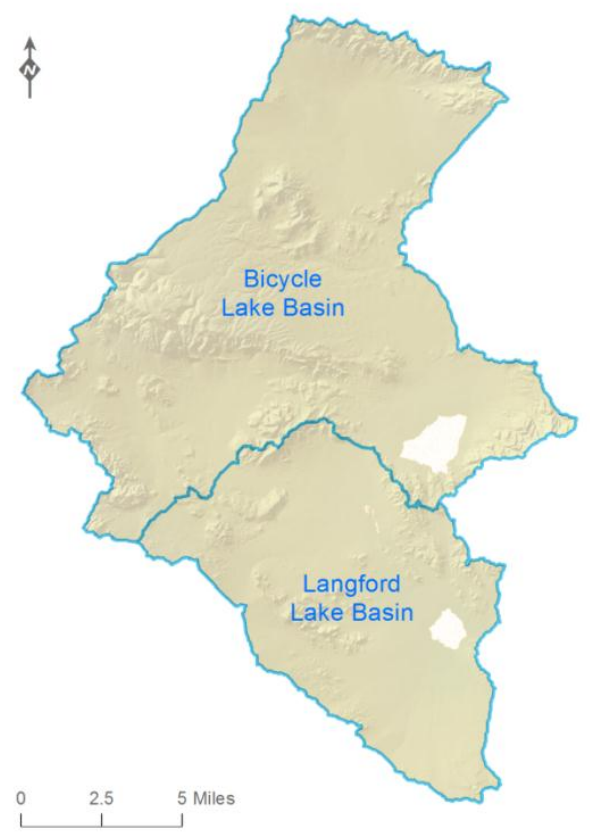

Figure 6.1: Natural basins 
The study area was also divided into drainage units on the basis of client identified storm water basins. The client currently pumps water from the Bicycle, Irwin, and Langford aquifers. The portion of the study area that contributes recharge water to each of these aquifers is considered as a storm water basin by the client. Delineating basins based on this parameter leaves the Bicycle Lake basin unchanged while it splits the Langford Lake basin in two. Figure 6.2 shows the results of delineation based on client identified storm water basins.

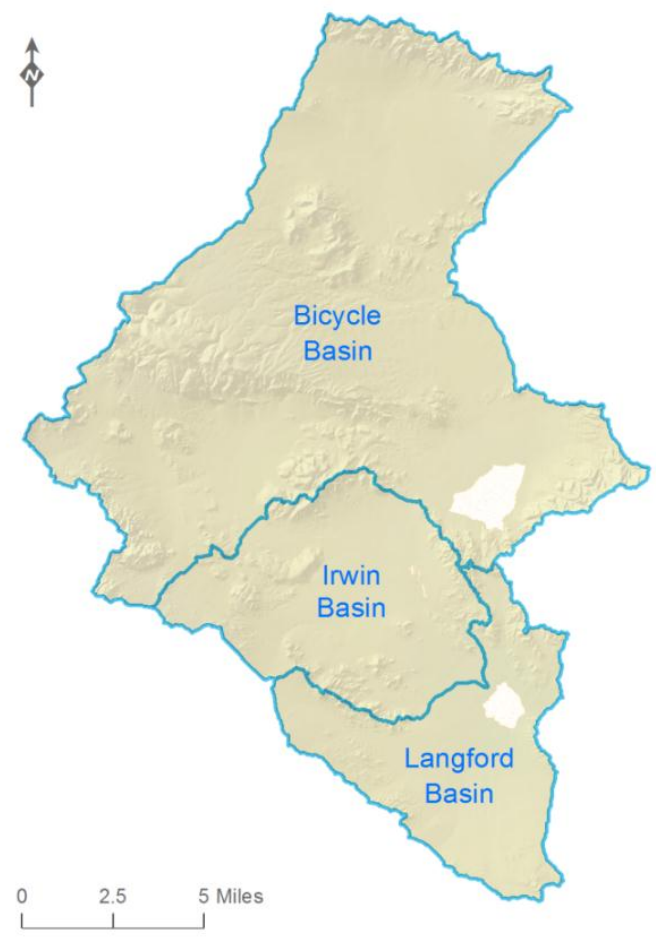

Figure 6.2: Storm water basins

The United States Geological Survey (USGS) developed a system that divides the United States into successively smaller drainage basins identified by a Hydrologic Unit Code (HUC). There are 6 division levels in this classification system. Each level has a size range. Where a single basin does not meet this requirement, it is aggregated with adjoining basins. The $6^{\text {th }}$ HUC level has a size range of $10-40,000$ acres, which made it possible to divide the two closed natural basins into smaller component basins. The HUC basin delineation splits the Bicycle Lake basin into four basins and also splits the Langford Lake basin into two basins which are the same as the Irwin and Langford storm water basins identified in section 6.1.2. The delineation results are presented in Figure 6.3 . 


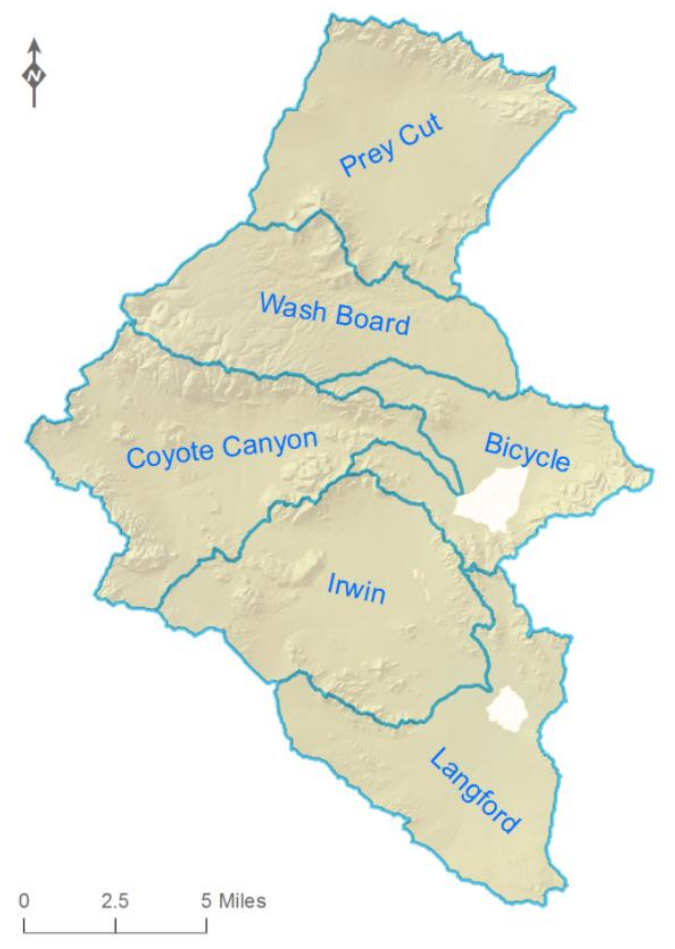

Figure 6.3: USGS HUC level 6 basins

\subsection{Peak Discharge Results and Analysis}

Peak discharge values were calculated for the natural basins and the HUC basins using the USGS equation method, and the Curve Number method. The USGS method was used to calculate peak discharges in cubic feet per second (cfs) for rain events with 2, 10, and 100 year return periods. Peak discharge rates were also calculated for the HUC basins and aggregated to the natural basins delineation level. This enabled a quantitative determination of the difference in peak discharge caused by dividing basins into smaller drainage units. USGS method results for the natural basins and HUC basins are presented in Tables 4 and 5.

Table 4. USGS method results for natural basins

\begin{tabular}{|l|r|r|r|}
\hline Basin Name & $\begin{array}{l}\text { 2 Year Peak } \\
\text { Discharge (cfs) }\end{array}$ & $\begin{array}{l}\text { 10 Year Peak } \\
\text { Discharge (cfs) }\end{array}$ & $\begin{array}{l}\text { 100 Year Peak } \\
\text { Discharge (cfs) }\end{array}$ \\
\hline Bicycle Lake & 207.40 & 4207.28 & 25220.74 \\
\hline Langford Lake & 142.02 & 2806.81 & 16073.95 \\
\hline
\end{tabular}


Table 5. USGS method results for HUC basins

\begin{tabular}{|c|c|c|c|}
\hline Basin Name & $\begin{array}{l}2 \text { Year Peak } \\
\text { Discharge (cfs) }\end{array}$ & $\begin{array}{l}10 \text { Year Peak } \\
\text { Discharge (cfs) }\end{array}$ & $\begin{array}{l}100 \text { Year Peak } \\
\text { Discharge (cfs) }\end{array}$ \\
\hline Prey Cut & 101.41 & 1958.25 & 10767.77 \\
\hline Wash Board & 86.78 & 1657.84 & 8946.10 \\
\hline Coyote & 103.82 & 2007.90 & 11072.04 \\
\hline Bicycle & 77.40 & 1466.92 & 7807.27 \\
\hline Irwin & 98.82 & 1904.84 & 10441.44 \\
\hline Langford & 91.08 & 1745.65 & 9475.03 \\
\hline
\end{tabular}

Aggregating the HUC results shown in Table 5 to the natural basin level led to large increases in USGS method peak discharge rates (23.1 - 79.5\%). See Appendix C for USGS method aggregated HUC Tables. The percentage of increase, however, diminished as the return period of rain events increased. A probable cause for the observed trend when results were aggregated may be the fact that the USGS equation for the study area has basin size as the only required input. The effect of basin size on peak discharge is probably exaggerated by the process of aggregating results from smaller drainage units.

The Curve Number method was also used to calculate peak discharge. This involved a more complex calculation model that required several basin attributes as inputs. Peak discharges was calculated for average, 2, 10, and 100 year return period rain events for both natural and HUC basins. An average rain event in this study refers to a rainstorm that has a likelihood of occurring at least once every year, so there is $100 \%$ chance of having at least one such event in a given year. The peak discharge rates for HUC basins were calculated and aggregated to determine the effect of aggregation on peak discharge rates. The natural basins and HUC basins results are shown in Tables 6 and 7.

Table 6. Curve Number results for natural basins

\begin{tabular}{|l|l|l|l|l|}
\hline Basin Name & $\begin{array}{l}\text { Average } \\
\text { Peak } \\
\text { Discharge } \\
\text { (cfs) }\end{array}$ & $\begin{array}{l}\text { 2 Year Peak } \\
\text { Discharge } \\
\text { (cfs) }\end{array}$ & $\begin{array}{l}\text { 10 Year Peak } \\
\text { Discharge } \\
\text { (cfs) }\end{array}$ & $\begin{array}{l}\text { 100 Year Peak } \\
\text { Discharge } \\
\text { (cfs) }\end{array}$ \\
\hline Bicycle Lake & 289.97 & 521.36 & 3222.30 & 8805.81 \\
\hline Langford Lake & 41.73 & 102.66 & 1056.28 & 3293.50 \\
\hline
\end{tabular}


Table 7. Curve Number results for HUC basins

\begin{tabular}{|l|r|r|r|r|}
\hline Basin Name & $\begin{array}{l}\text { Average Event } \\
\text { Peak } \\
\text { Discharge (cfs) }\end{array}$ & $\begin{array}{l}\text { 2 Year Peak } \\
\text { Discharge } \\
\text { (cfs) }\end{array}$ & $\begin{array}{l}\text { 10 Year Peak } \\
\text { Discharge } \\
\text { (cfs) }\end{array}$ & $\begin{array}{l}\text { 100 Year Peak } \\
\text { Discharge (cfs) }\end{array}$ \\
\hline Prey Cut & 95.83 & 167.23 & 988.09 & 2678.35 \\
\hline Wash Board & 87.35 & 146.20 & 796.23 & 2094.73 \\
\hline Coyote & 122.46 & 205.32 & 1109.82 & 2901.85 \\
\hline Bicycle & 14.98 & 36.44 & 377.89 & 1191.52 \\
\hline Irwin & 65.53 & 120.83 & 790.86 & 2188.68 \\
\hline Langford & 3.89 & 13.19 & 313.44 & 1154.29 \\
\hline
\end{tabular}

The results from the Curve Number method also exhibited a trend of increase in peak discharge for storm events when the HUC basins peak discharge rates were aggregated. See Appendix C for Curve Number method aggregated HUC basin results. The effect of aggregation was, however, much less than with the USGS method, as the increases were generally no more than 10 percent. The exceptions were the average and 2 year event peak discharge for Langford basin which increased by $66.57 \%$ and $31.4 \%$ respectively after aggregation. The large increases in the two exceptional cases may be due to the fact that input parameters of the Curve Number equation get averaged out at the natural basin level. Table 7 shows that most of the discharge for the larger Langford Lake basin comes from the Irwin HUC basin (65.5 cfs) while the Langford HUC basin only contributes a small amount (3.9 cfs). The low peak discharge of the Langford HUC basin probably led to a much lower discharge for the Langford Lake basin when calculations were done at the natural basin level.

The peak discharge estimates from the USGS and Curve Number methods were compared, and were found to differ by a large amount. The natural basins results from the two methods are shown in Figure 6.4

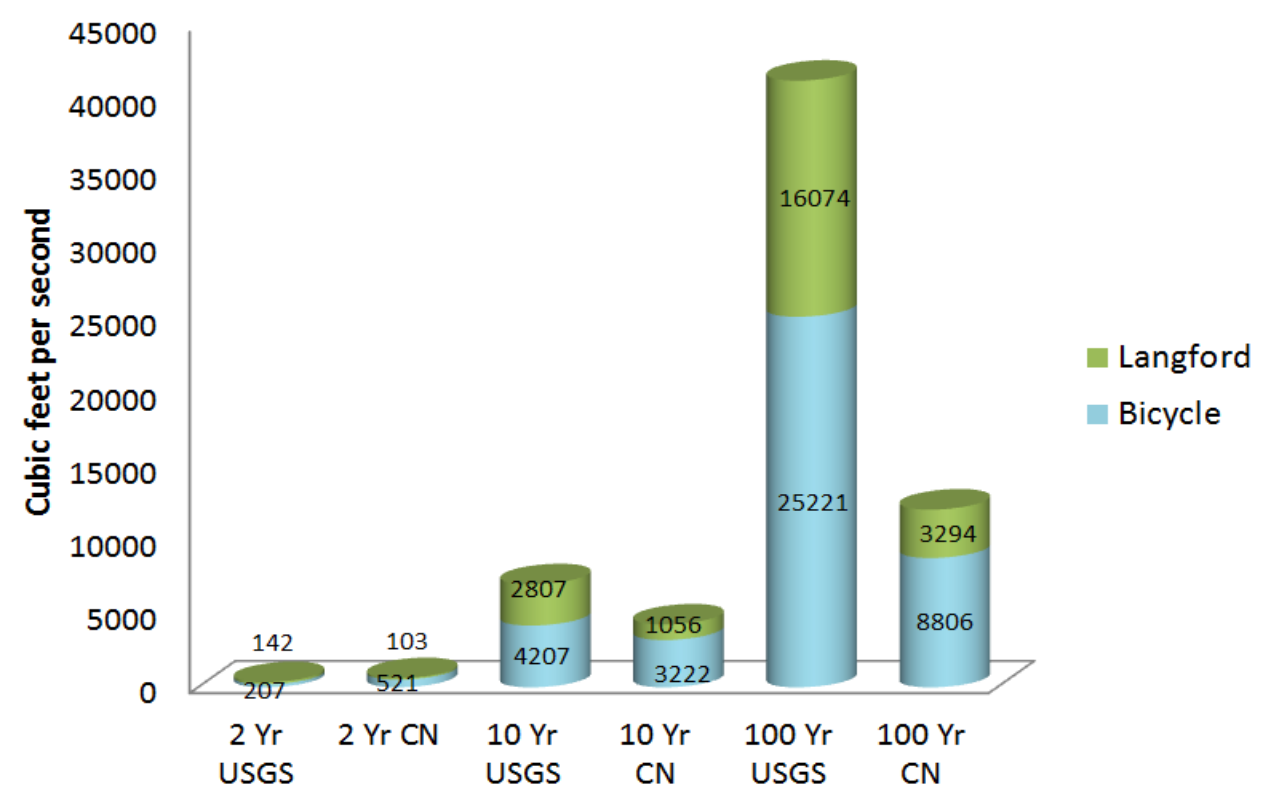

Figure 6.4: Peak discharge results from USGS and Curve Number methods 
Compared to the Curve Number method, the USGS method produced lower estimates of 2 year peak discharge. The USGS method however produced comparatively larger estimates of 10 and 100 year peak discharge rates. The USGS method is a regional model that has basin size as the sole input. It can therefore be considered as a simple model which is suitable for quick estimates of peak discharge. The Curve Number model required several inputs and was developed to consider local hydrologic characteristics. Therefore its results are likely to be more accurate than results from the USGS model.

\subsection{Runoff Volume Results and Analysis}

Runoff volume was calculated for the average year as well as rain events with different return periods. The average annual runoff volume was then computed and compared to the annual water usage to determine the feasibility of rainfall capture.

The Curve Number method was used to calculate runoff volume for average, 2, 10 , and 100 year rain events for the storm water basins and the results are shown in figure 6.5. Calculating runoff volumes at the level of the storm water basin helped determine the amount of water available in each of the basins overlying the aquifers from which Fort Irwin currently draws water. The low level of runoff generated in the Langford storm water basin also became evident.

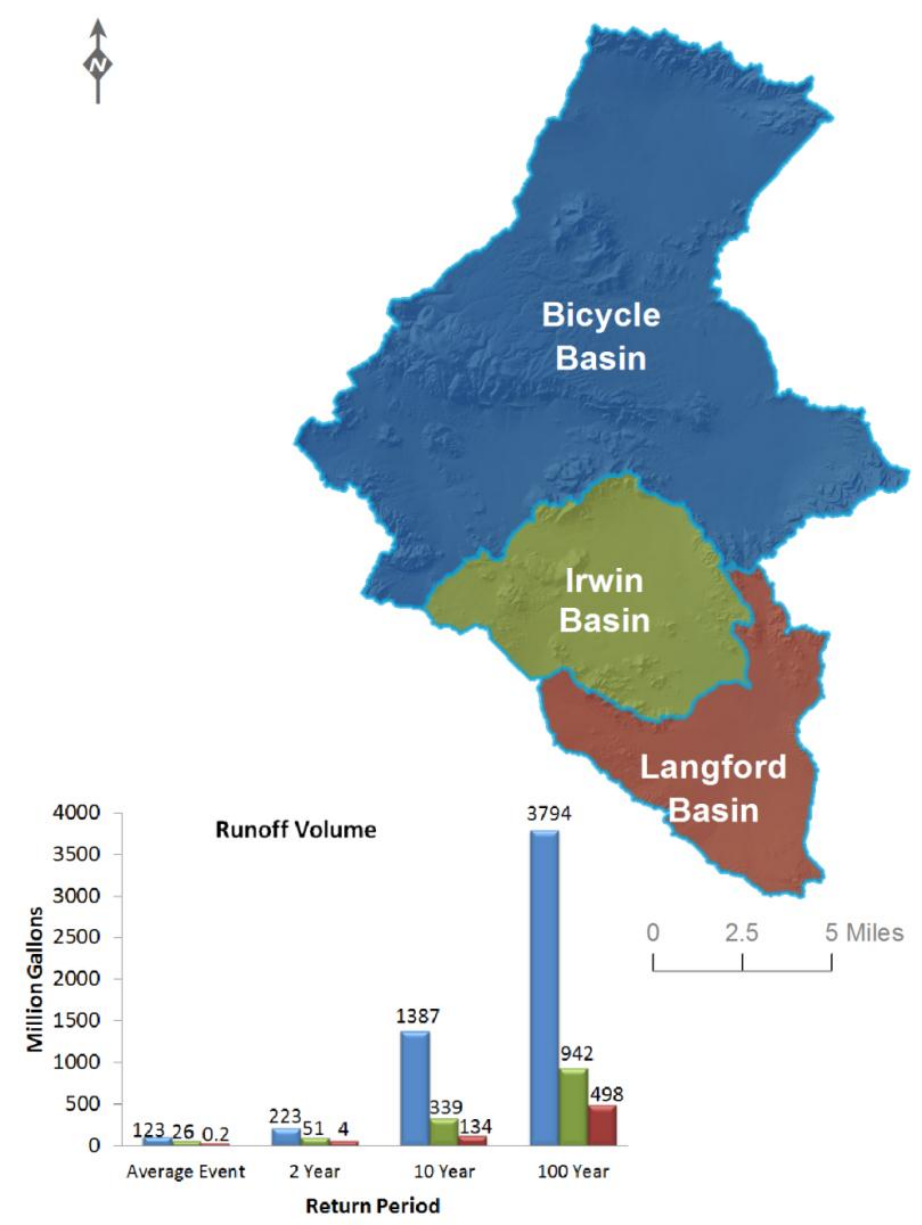

Figure 6.5: Runoff volumes for storm water basins 
The Curve Number model considers input rainfall data as representative of a single rainfall event rather than a series of individual events. As such it was not suitable for estimating average annual runoff. A different methodology was therefore adopted to estimate average annual runoff. This involved dividing the annual average rainfall by the average event rainfall to get an estimate of the number of rain events that occur in each basin in a given year. Average annual runoff was then estimated through the multiplication of average runoff volume by the number of rain events in a year. The results are shown in Table 8.

Table 8. Estimated average annual runoff volume

\begin{tabular}{|l|l|l|l|l|l|}
\hline Basin Name & $\begin{array}{l}\text { Average } \\
\text { Annual } \\
\text { Rainfall } \\
\text { (inches) }\end{array}$ & $\begin{array}{l}\text { Average } \\
\text { Rainfall } \\
\text { Event } \\
\text { (inches) }\end{array}$ & $\begin{array}{l}\text { No of Rain } \\
\text { Events }\end{array}$ & $\begin{array}{l}\text { Average } \\
\text { Event } \\
\text { Runoff } \\
\text { (MG) }\end{array}$ & $\begin{array}{l}\text { Annual } \\
\text { Runoff } \\
\text { volume } \\
\text { (MG) }\end{array}$ \\
\hline Bicycle & 5.45 & 0.95 & 5.74 & 123 & 718 \\
\hline Irwin & 5.09 & 0.90 & 5.65 & 26 & 150 \\
\hline Langford & 4.96 & 0.84 & 5.90 & 0.2 & 1 \\
\hline Total & & & & & \\
\hline
\end{tabular}

Fort Irwin is making efforts to reduce water usage through several conservation initiatives. Figure 6.6 presents the annual volume of water used on the base between 2005 and 2011.

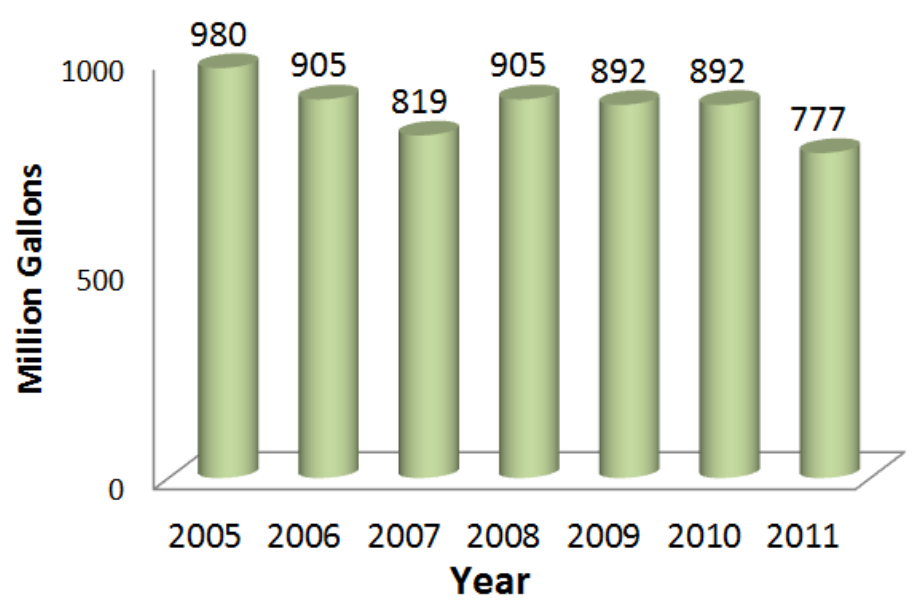

Figure 6.6: Annual water usage

The annual volume of water used on Fort Irwin between 2005 and 2011 varied between 777 to 980 million gallons. The water usage has decreased over time with a low of 777 million gallons achieved in 2011. Total runoff generated from storm water was estimated at 869 million gallons for an average year as shown in Table 8 . This means the estimated average annual volume of storm water can potentially offset water usage at or near the 2011 level.

Most of the runoff available in the study area is generated in the Bicycle basin (718 million gallons/annum). The Irwin basin generates a much smaller amount of runoff 
(150 million gallons/annum) while the Langford basin generates very little runoff (1 million gallons/annum). Based on these results, efforts at using storm water for aquifer recharge should be concentrated on the Bicycle basin. The Irwin basin also generates enough runoff to make storm water capture feasible within it. The low volume of runoff in Langford basin means it would not be viable to implement a storm water capture scheme within it. To make storm water capture feasible within the Langford basin, some of the runoff from Bicycle or Irwin basin would have to be diverted. The low volume of runoff generated in the Langford basin suggests that it has a much higher rate of infiltration compared to the other basins. If this is the case it would also have a higher rate of natural recharge.

Based on this result, it can be inferred that storm water capture is viable in the study area and can contribute a sizeable proportion of the water needed for aquifer recharge as Fort Irwin seeks to achieve Net Zero Water Use. Water capture efforts should however be concentrated on the Bicycle basin. Other conservation methods may also be adopted to offset water pumped from the Irwin and Langford basins.

\subsection{Suitability Model Results}

The suitability model was used to evaluate several factors including infiltration, runoff, elevation, and slope for the identification of candidate sites for water capture. The results from the suitability model are presented in the three diagrams in Figure 6.7.
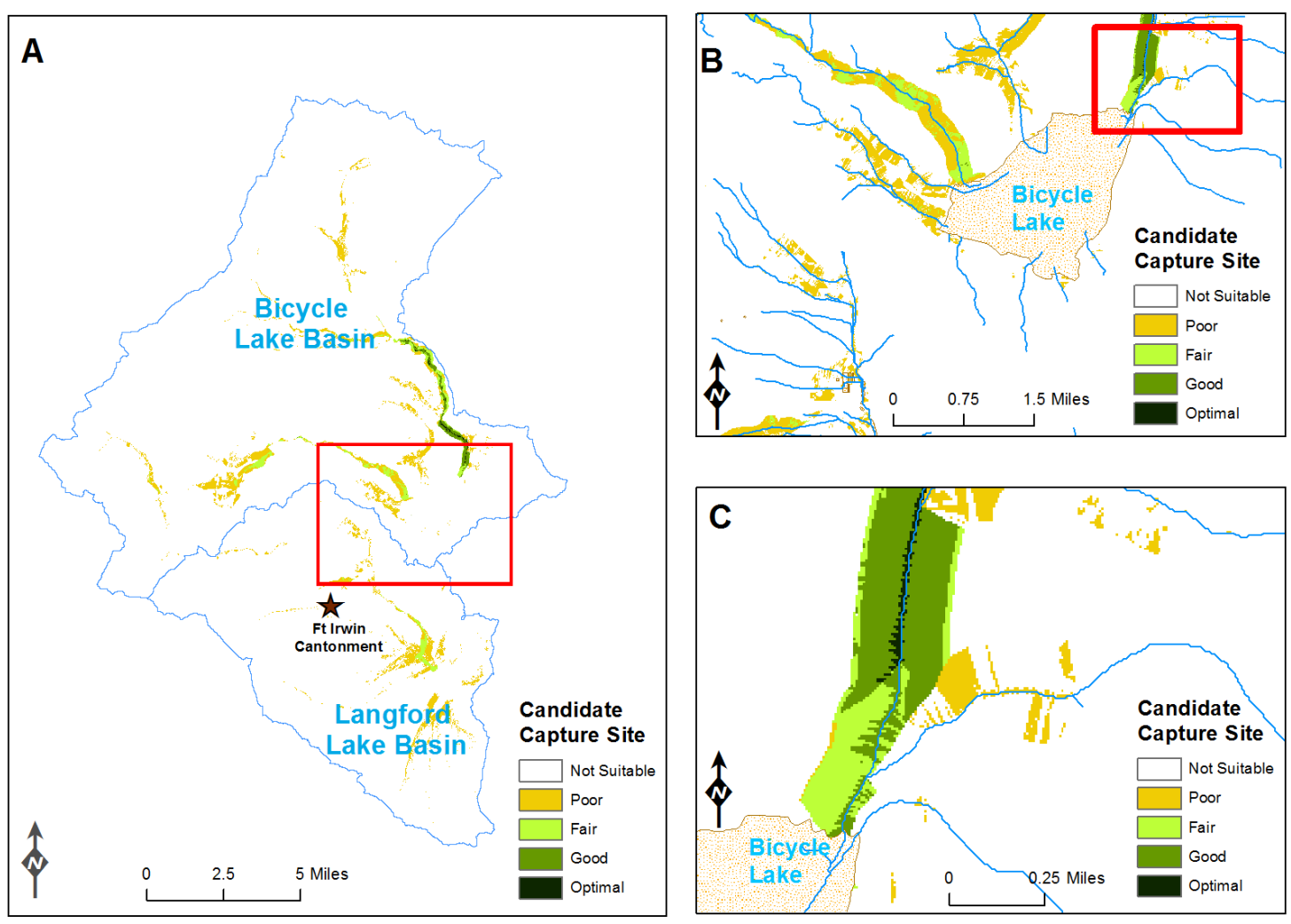

Figure 6.7: Ranked candidate water capture sites 
Diagram A shows an overview map of the whole study area encompassing the Bicycle and Langford lake basins. Suitable candidate sites are ranked and shown in varying shades of green while unsuitable areas are in white. In diagram B which shows a close up of the Bicycle Lake basin, it becomes apparent that suitable candidate sites are within a short distance of streams. This is due to the high weight given to distance from streams in the suitability analysis model. This would make it fairly easy to divert runoff from stream channels to suitable candidate sites. A small portion of the study area near Bicycle Lake is shown in diagram $\mathrm{C}$. The detailed view shows that good and optimal candidate sites were not located close to the lakes, rather they were located some distance upstream. This is probably because areas close to the lakes may not have good infiltration rates in spite of the high runoff volume they experience. The optimal sites were however either along the stream channels or adjacent to them. The fact that areas with good infiltration rates tend to occur near to or within stream channels may partly explain the observed spatial distribution of optimal sites.

\subsection{Summary}

This chapter presented the analysis and results from the tools created for this project. Drainage basins were delineated for the study area based on different criteria. Peak discharge for the delineated basins was calculated using the USGS and Curve Number methods. Aggregating smaller basins was found to lead to increases in estimated peak discharge for larger basins. This effect was much more pronounced with the USGS model. Runoff volume was calculated for rain events with different return periods and the result from the average event calculation was used in estimating annual runoff volume for the storm water basins. The estimated annual runoff volume was found to be adequate as a source of water for aquifer recharge in the Bicycle basin. Water capture may also meet some of the aquifer recharge demand of the Irwin basin while the runoff volume in Langford basin does not justify water capture attempts within it. The results of the suitability analysis identified candidate sites for storm water capture within each of the storm water basins. The tools and results produced in the course of this study are modifiable and repeatable while the maps are easy to understand, thus fulfilling the client's functional requirements. 



\section{Chapter 7 - Conclusions and Future Work}

The US Army Net Zero Water Use program seeks to limit the consumption of fresh water on army installations and return the same amount of water that they use to the source watershed every year. Fort Irwin is a US Army base located in the Mojave desert and derives its water needs from aquifers which are becoming depleted with time. Balancing water use on the base within the Net Zero Water Use framework requires a combination of several conservation methods, one of which is storm water capture to aid aquifer recharge. This study developed GIS tools to facilitate basin delineation, peak discharge and runoff volume calculation, and identification of candidate sites for storm water capture within each basin.

Arc Hydro tools were adapted to create datasets necessary for basin delineation. The datasets were then used to delineate three sets of basins based on different criteria. The USGS and Curve Number runoff estimation models were integrated with ArcGIS through a set of custom tools created in Model Builder. Basin parameters including runoff depth, peak discharge, and runoff volume, were calculated using the custom models. The results helped determine the viability of storm water capture in the basins within the study area.

The total volume of runoff generated was found to be enough to make water capture feasible at Fort Irwin. The volume of runoff generated in the Irwin and Langford basins was however found to be much lower than the volume generated in the Bicycle basin. As such, storm water generated within these basins cannot be the sole source of water for recharging the underlying aquifers. Storm water must either be diverted from the Bicycle basin or other methods must be identified and developed to improve recharge of the Irwin and Langford aquifers. A suitability analysis workflow was also created to help determine parts of the study area best suited for storm water capture. The results from the suitability analysis identified candidate areas where on-site physical surveys may be conducted to evaluate actual suitability for storm water capture.

The Curve Number factor input to the suitability analysis model was classified using the natural breaks method. The equal interval method may be used as an alternative classification scheme for this input in future.

This study was limited to a desktop application. In future, the project tools may be further customized to enable use over the internet with improved speeds. Improvements to the basin delineation and peak discharge calculation tools, for example, may make it possible to deploy them as web services accessible to a wide range of potential users.

It was not possible to calibrate the runoff models created for this study because Fort Irwin does not collect data that are suitable for this purpose. The effect of evaporation on runoff was also not considered. Future studies may concentrate on using data from nearby gauged streams to calibrate and refine the runoff estimates produced by the runoff models. Data from the nearby Mojave river gauging station in Barstow may be investigated to determine if they would be ideal for this purpose. Evapotranspiration rates may also be computed to determine how much runoff would be lost through natural processes. Other studies may help determine the effect of infiltration rate and other contributory factors to the low volume of runoff generated in the Langford basin. 
At present the suitability analysis model only provides a weighted score for candidate sites. Additional future work may involve modifications that make it possible to query the contribution of each factor to the weighted score of a candidate location. The ability to identify weights of different contributing factors would help in prioritizing candidate locations for physical surveys.

In conclusion, results from this study suggest that storm water capture can be implemented as part of Fort Irwin's efforts to achieve Net Zero Water Use. Such efforts should be concentrated on the Bicycle basin which generates a much larger volume of runoff than the other basins in the study area. 


\section{Works Cited}

Boers, T. M. (1994). Rainwater Harvesting in Arid and Semi-Arid Zones. Wageningen, Netherlands: International Institute for Land Reclamation and Improvement.

Cascadia Green Building Council. (2011). Regulatory Pathways to Net Zero WaterGuidance for Innovative Water Projects in Seattle. Seattle: Cascadia Green Building Council. Retrieved February 10, 2012, from http://cascadiagbc.org/resources/RegulatoryPathwaystoNetZeroWater.pdf

Comrie, A., \& Broyles, B. (2002). Variability and Spatial Modelling of Fine-Scale Precipitation Data for the Sonora Desert of South West Arizona. Journal of Arid Environments, 50, 573-592. Retrieved February 16, 2012, from http://home.shirazu.ac.ir/ kompani/DryLandHydrology/papers8788/comriesonoranPrecipitation-JOAE2002.pdf

Densmore, J. N. (2003). Simulation of Ground-Water Flow in the Irwin Basin Aquifer System, Fort Irwin National Training Center, California. Sacramento: United States Geological Survey (USGS). Retrieved January 27, 2012, from http://pubs.usgs.gov/wri/wri024264/024264.book.pdf

EasterBrook, R. (2006). Predicting Post-Wildfire Watershed Runoff Using ArcGIS ModelBuilder. Esri Federal User Conference Proceedings 2006. Washington DC: Esri.

Ebrahimian, M., See, L. F., Ismail, M. H., \& Malek, I. A. (2009). Application of Natural Resources Conservation Service-Curve Number Method For Runoff Estimation in the Kardeh Watershed Iran. European Journal of Scientific Research, 34(4), 575590. Retrieved July 15, 2012, from http://www.eurojournals.com/ejsr_34_4_14.pdf

Elfeki, A., \& Al-Amri, N. (2011). Modelling Monthly Rainfall Records in Arid Zones using Markov Chains: Saudi Arabia Case Study. International Journal of Water Resources and Arid Environments, 1(6), 411-416. Retrieved from http://www.psipw.org/attachments/article/308/IJWRAE_1(6)411-416.pdf

Gupta, K., Deelstra, J., \& Sharma, K. (1997). Estimation of Water Harvesting Potential for a Semiarid Area Using GIS and Remote Sensing. Remote Sensing and Geographic Information Systems for Design and Operation of Water Resources Systems (Proceedings of the Rabat Symposium) (pp. 53-62). Rabat: IAHS.

Hammouri, N., \& El-Naqa, A. (2007). Hydrological Modelling of Ungaged Wadis in Arid Environments using GIS: A Case Study of Wadi Madoneh in Jordan. Revista Mexicana de Ciencas Geologicas, 24(2), 185-196. Retrieved February 16, 2012, from http://satori.geociencias.unam.mx/24-2/(5)Hammouri.pdf

Inamder, S. C., Sharma, A., Corby, N., O'Connor, J., \& Perera, B. J. (2011). Development of a GIS Based Screening Tool for Evaluating Stormwater Harvesting Sites in Urban Areas. 19th International Congress on Modelling and Simulation. Perth, Australia. Retrieved July 2012, from http://www.mssanz.org.au/modsim2011/I1/inamdar.pdf

Kirkby, D., Pegler, K., \& Coleman, D. (2011). GIS for Hydrological Modelling. The Global Magazine for Geomatics, 25(7), pp. 23-27.

Maidment, D. R. (2002). Arc Hydro: GIS for Water Resources. Redlands: Esri Press. 
Martin, P., Lebeof, J., Dobbins, J., Daniel, E., \& Abkowitz, M. (2005). Interfacing GIS with Water Resources Models: A State of The Art Review. Journal of the American Water Resources Association, 1471-1487.

Mblinyi, B. P., Tumbo, S. D., Mahoo, H. F., \& Mkiramwinyi, F. O. (2007). GIS Based Decision Support System for Identifying Potential Sites for Rainwater Harvesting. Physics and Chemistry of the Earth, 30(11-16), 792-8. Retrieved from http://bscw.ihe.nl/pub/nj_bscw.cgi/d2607611/Mbilinyi\%20.pdf

McGee, J. R. (2009, Winter). Calculating Pervious Curve Numbers: A Custom Tool Built Using ArcGIS Diagrammer and Modelbuilder. ArcUser, pp. 54 - 57.

Natural Resource Conservation Services. (1986). Urban Hydrology for Small Watersheds: Technical Release 55. Natural Resource Conservation Service, Conservation Engineering Division. Washington DC: United States Department of Agricuture. Retrieved September 2012, from https://engineering.purdue.edu/mapserve/sedspec/doc/tr55

Olivera, F., Valenzuela, M., Srinivasan, R., Janghwoan, C., Cho, H., Koka, S., \& Agrawal, A. (2006). ARCGIS-SWAT: A Geodata Model and GIS Interface for SWAT. Journal of American Water Resources Association, 295-309. Retrieved February 17, 2012, from http://onlinelibrary.wiley.com/doi/10.1111/j.17521688.1987.tb00794.x/pdf

Oweis, T., Prinz, D., \& Hachum, A. (2001). Water Harvesting: Indeginous Knowledge for the Future of Drier Environment. Aleppo, Syria: International Center for Agricultural Research in Dry Area (ICARDA).

Sharma, A., \& Singh, V. V. (2012). Identification of Potential Runoff Harvesting Sites in a Water Scarce Rural Area Using GIS Approach. India Water Week 2012-Water Energy and Food Security: Call for Solutions. New Delhi. Retrieved September 17, 2012, from http://indiawaterweek.water.tallyfox.com/filefieldprivate/files/9376/field_document_plus/5605

Soil Conservation Service. (1973). A Method for Estimating Volume and Rate of Runoff in Smal Watersheds. US Department of Agriculture.

Stuart, N., \& Stocks, C. (1993). Hydrological Modelling within GIS: An Integrated Approach. Proceedings of the Vienna Conference (pp. 319-329). Vienna: International Association of Hydrological Sciences.

Thomas, B. E., Hjalmarson, H. W., \& Waltemeyer S D. (1997). Methods for Estimating Magnitude and Frequency of Floods in the Southwestern United States. Denver: USGS.

US Army. (2012). Army Vision for Net Zero. Retrieved January 27, 2012, from Army Energy Program: http://army-energy.hqda.pentagon.mil/netzero/ 


\section{Appendix A. Runoff and Suitability Analysis Models}

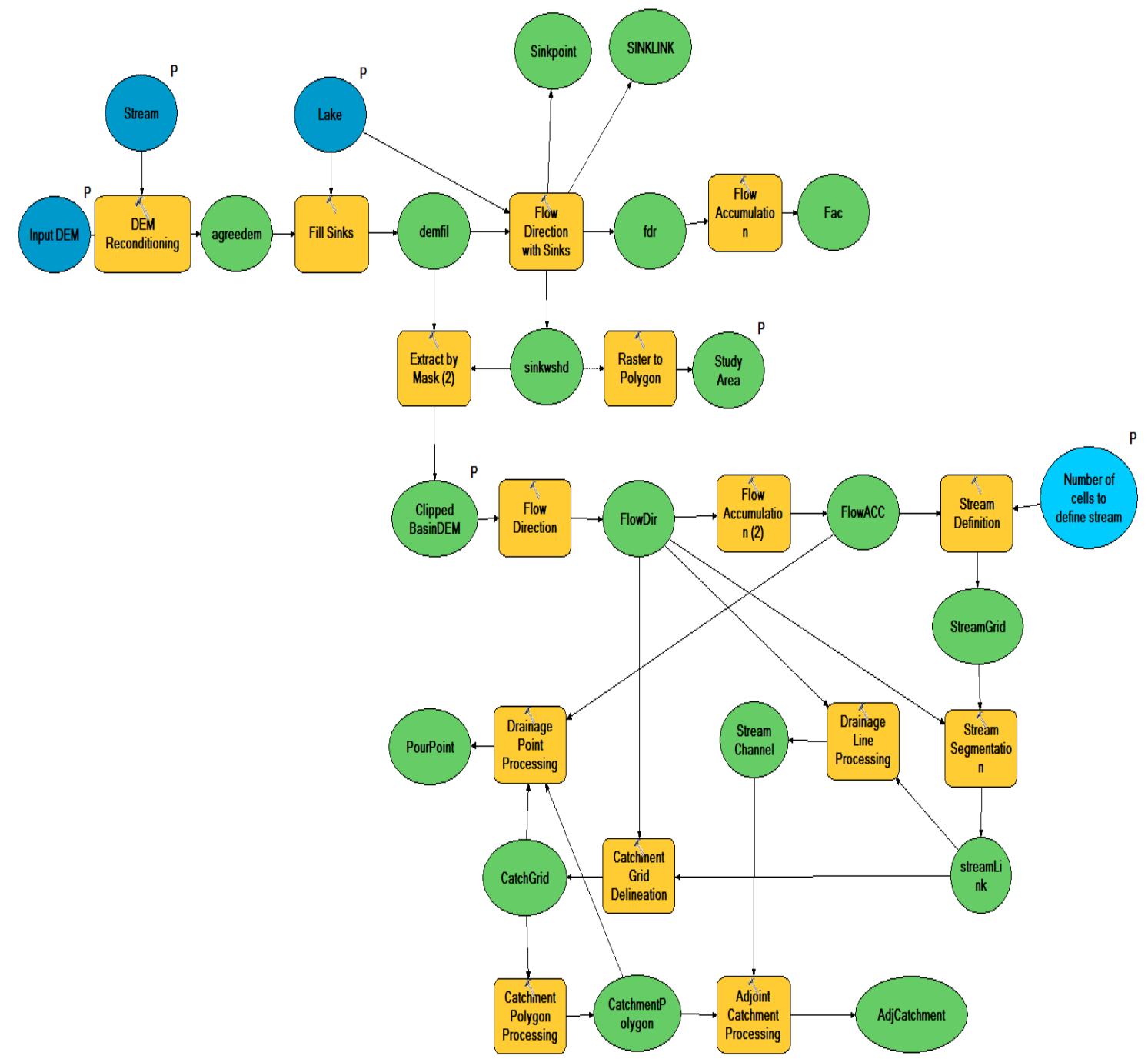

Figure A-1: Basin pre-processing model 


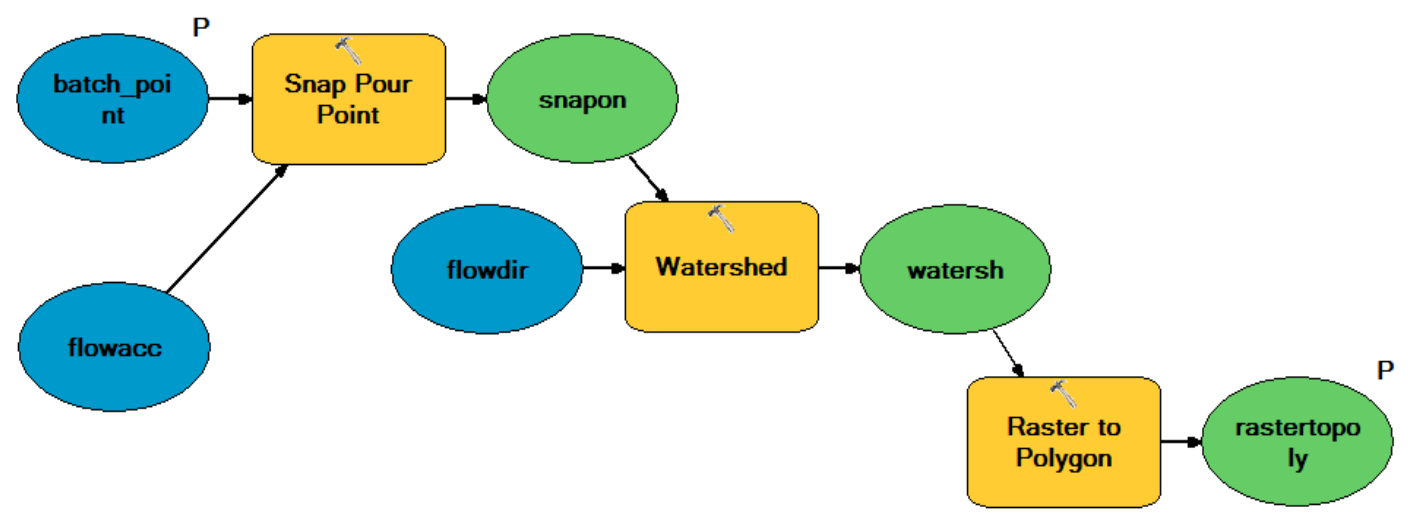

Figure A-2: Interactive basin delineation model

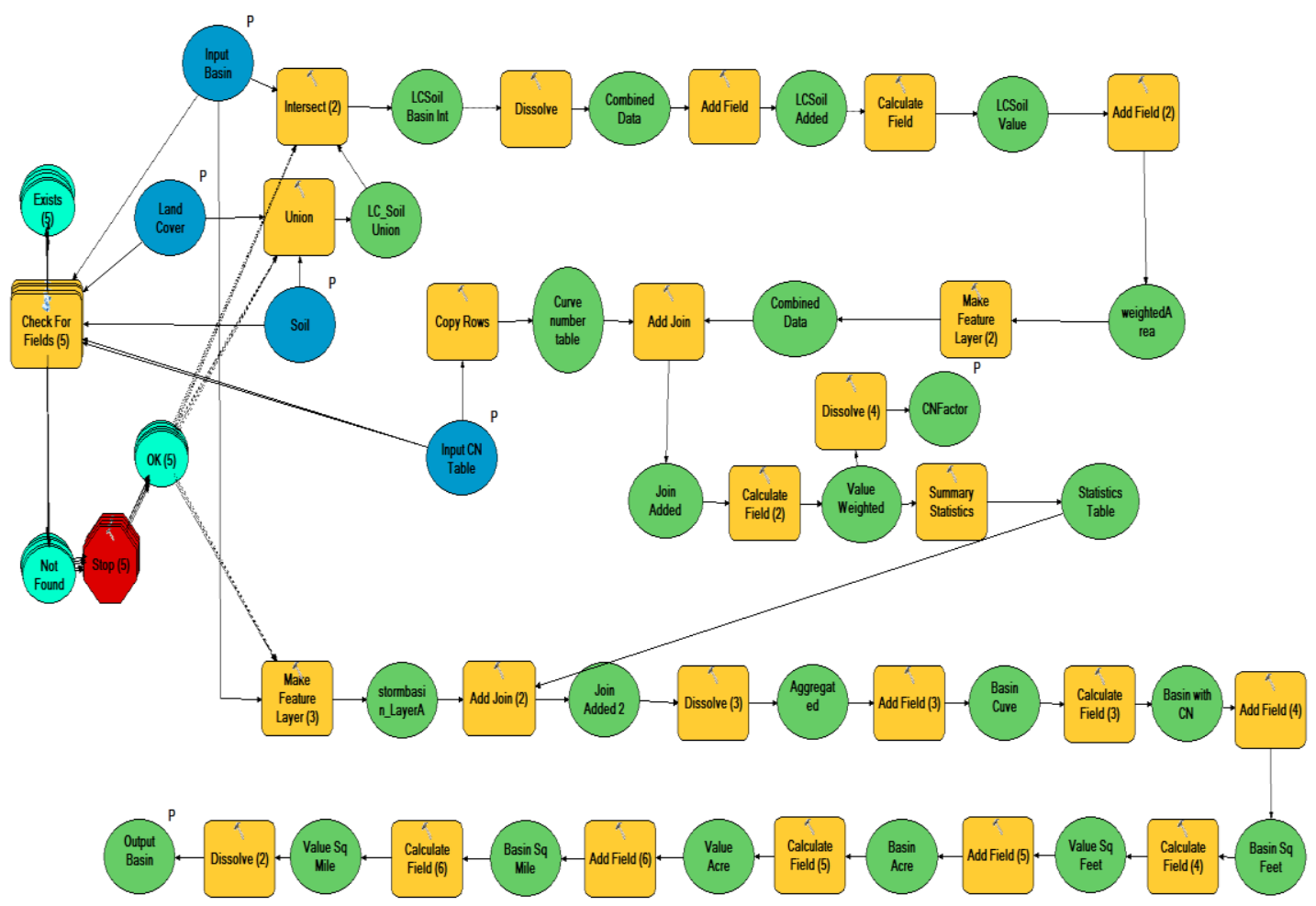

Figure A-3: Mean basin curve number calculation model 


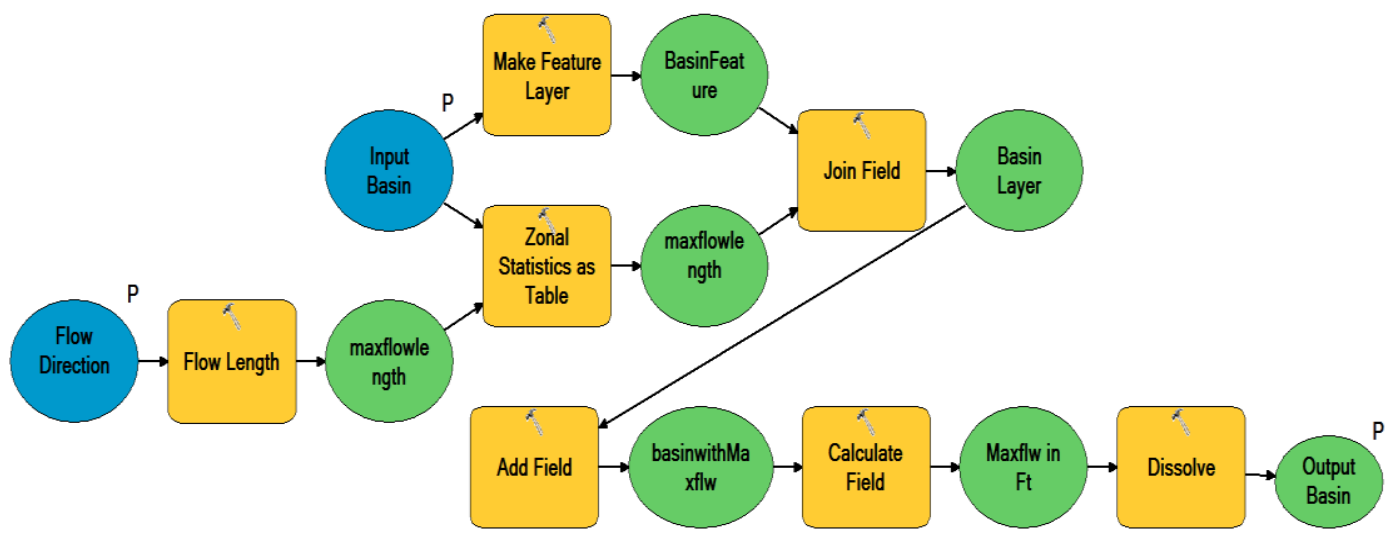

Figure A-4: Mean basin length model

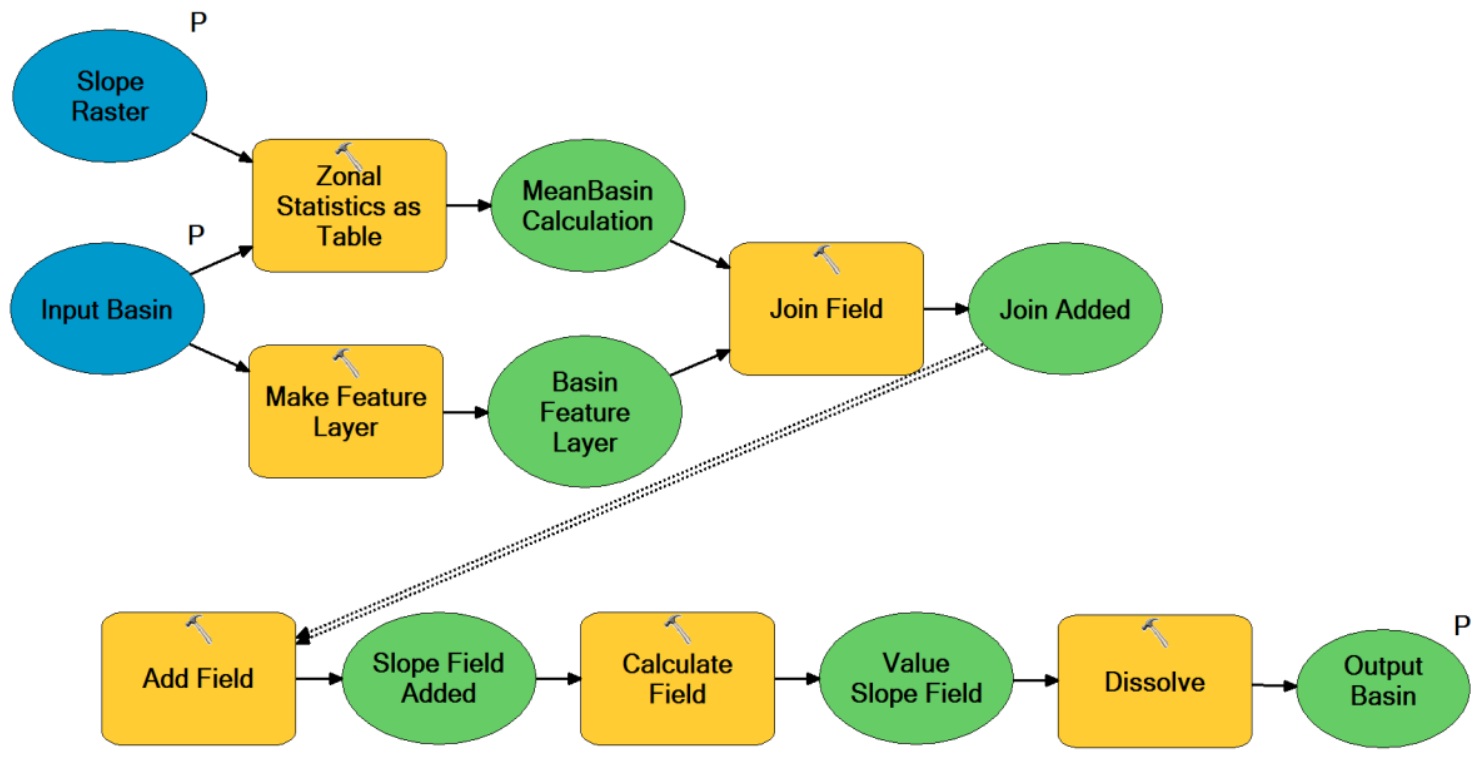

Figure A-5: Mean basin slope model 


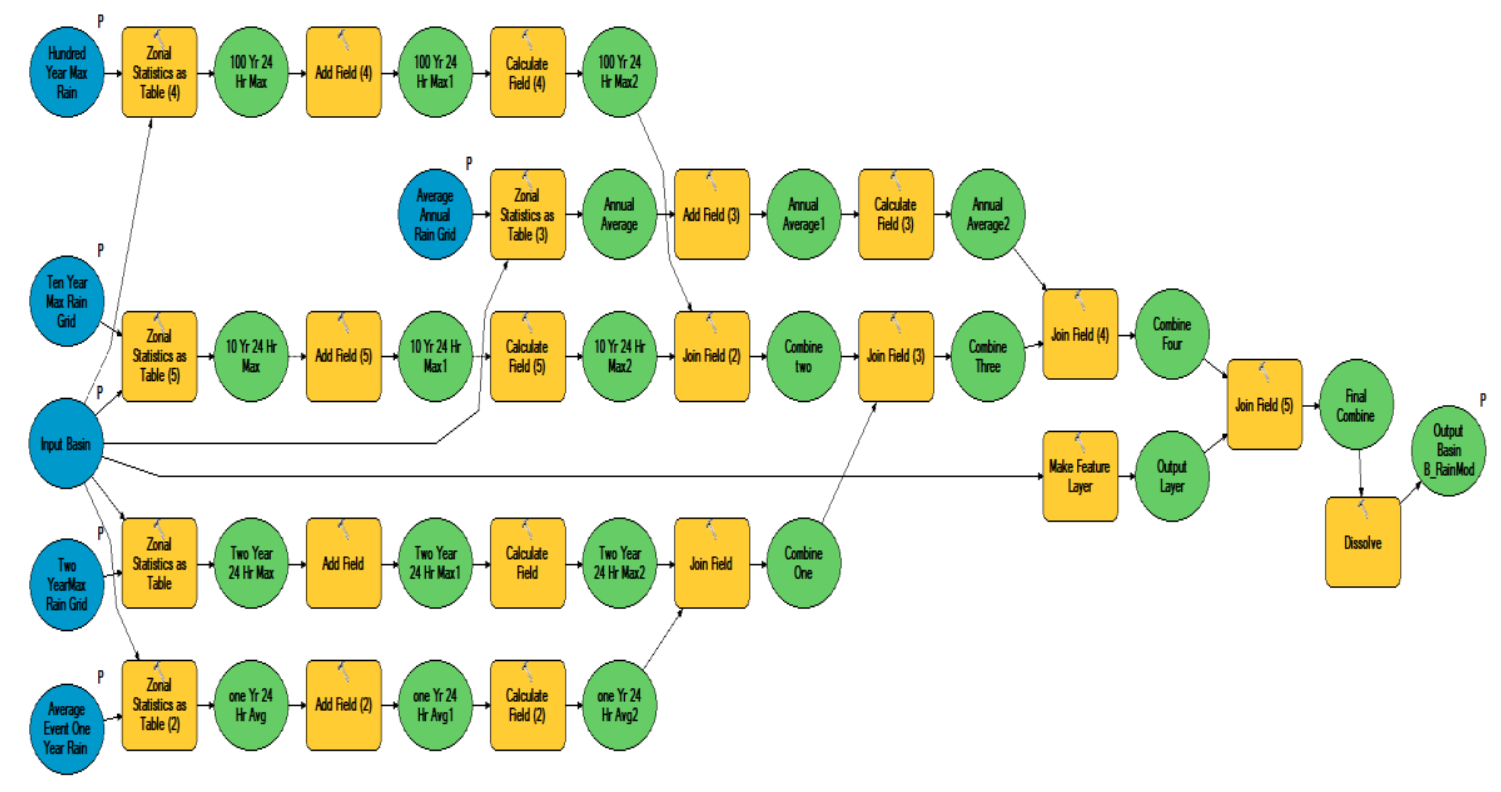

\section{Figure A-6: Mean basin rainfall model}

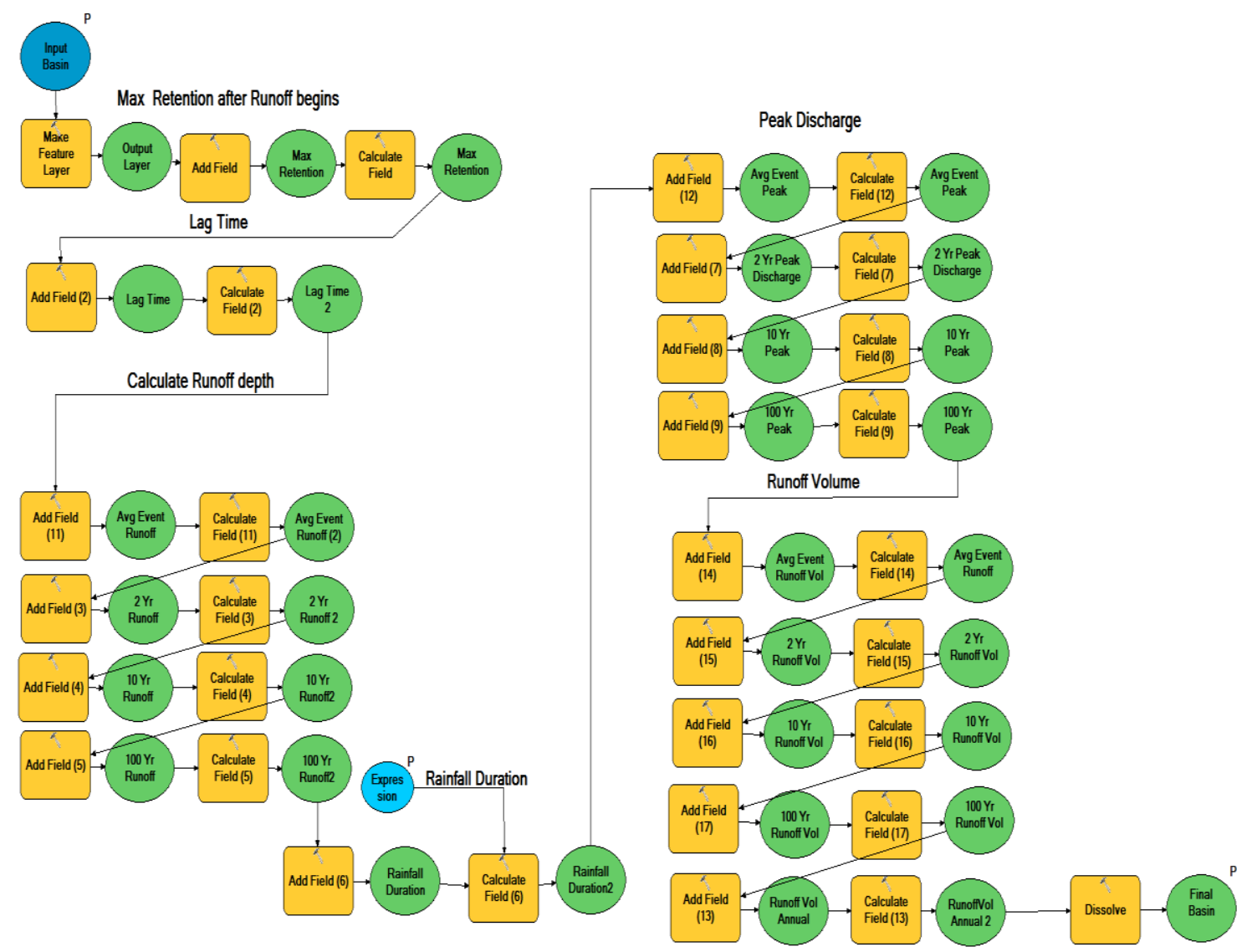

Figure A-7: Runoff calculations model 


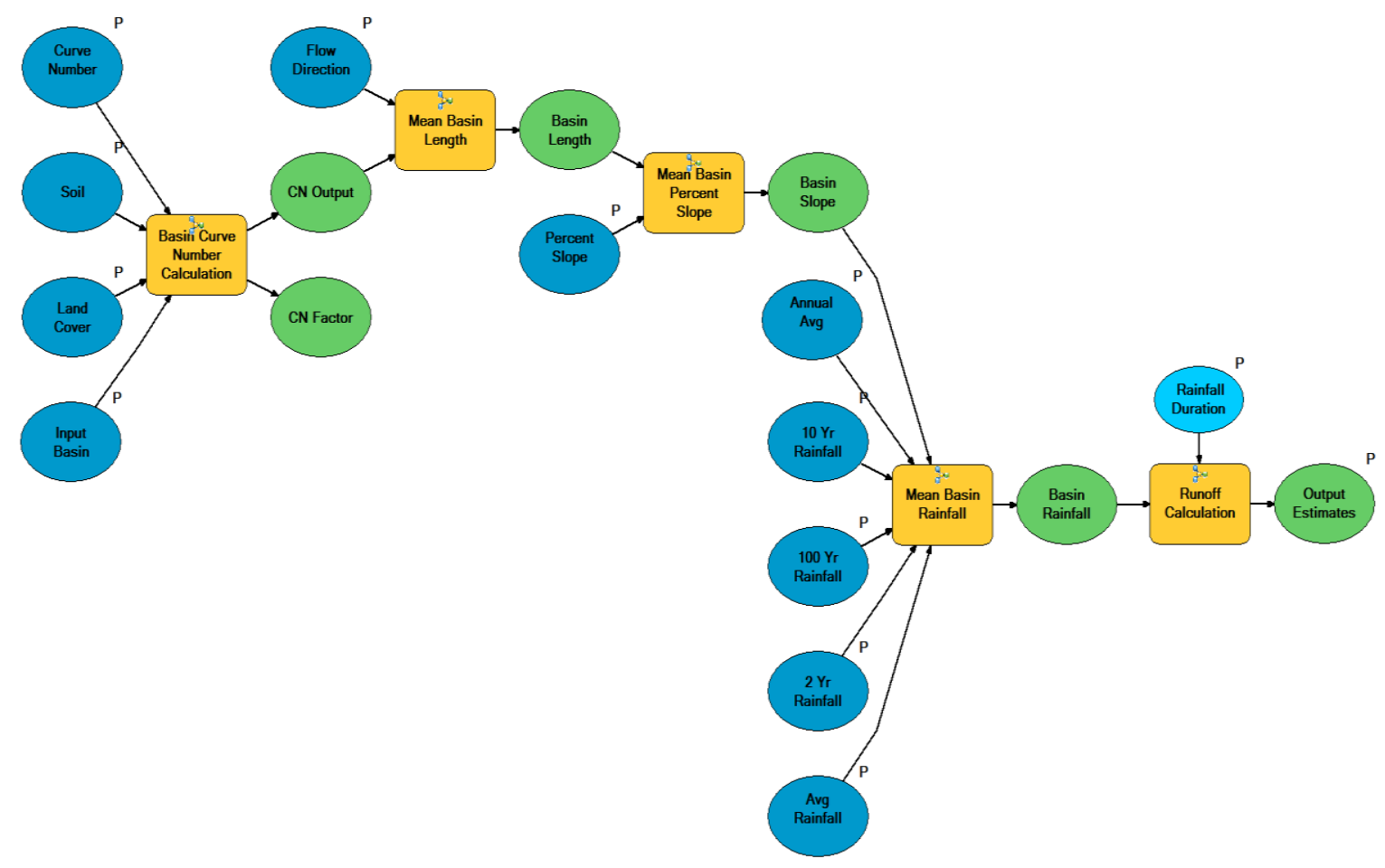

Figure A-8: Combined Curve Number runoff estimation model

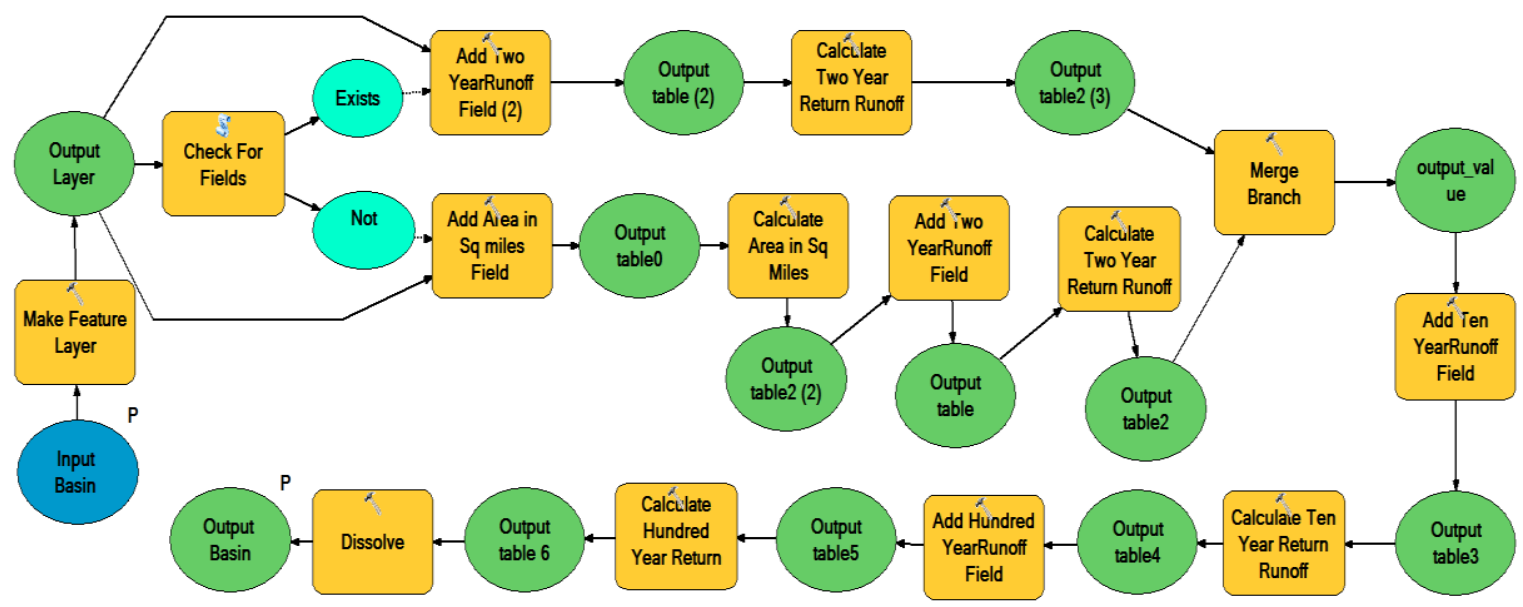

Figure A-9: USGS peak discharge estimation model 


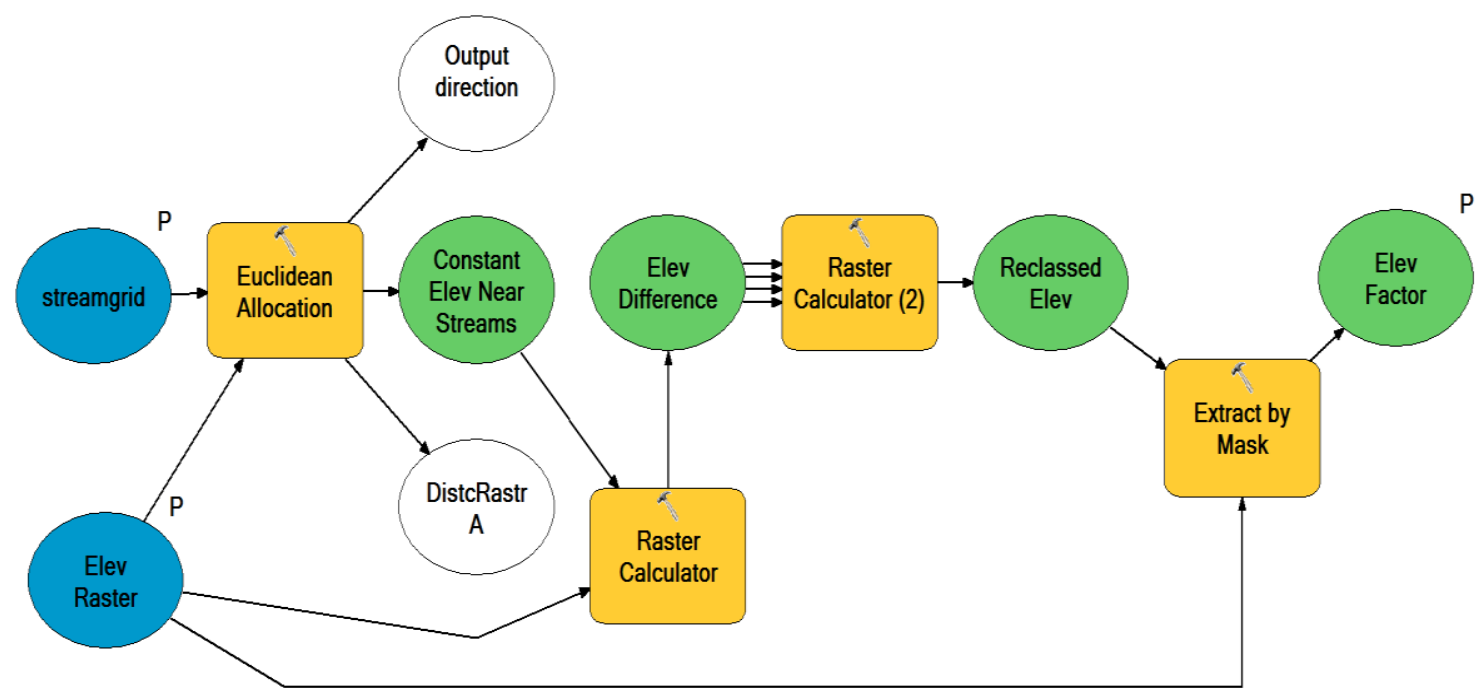

Figure A-10: Elevation factor model

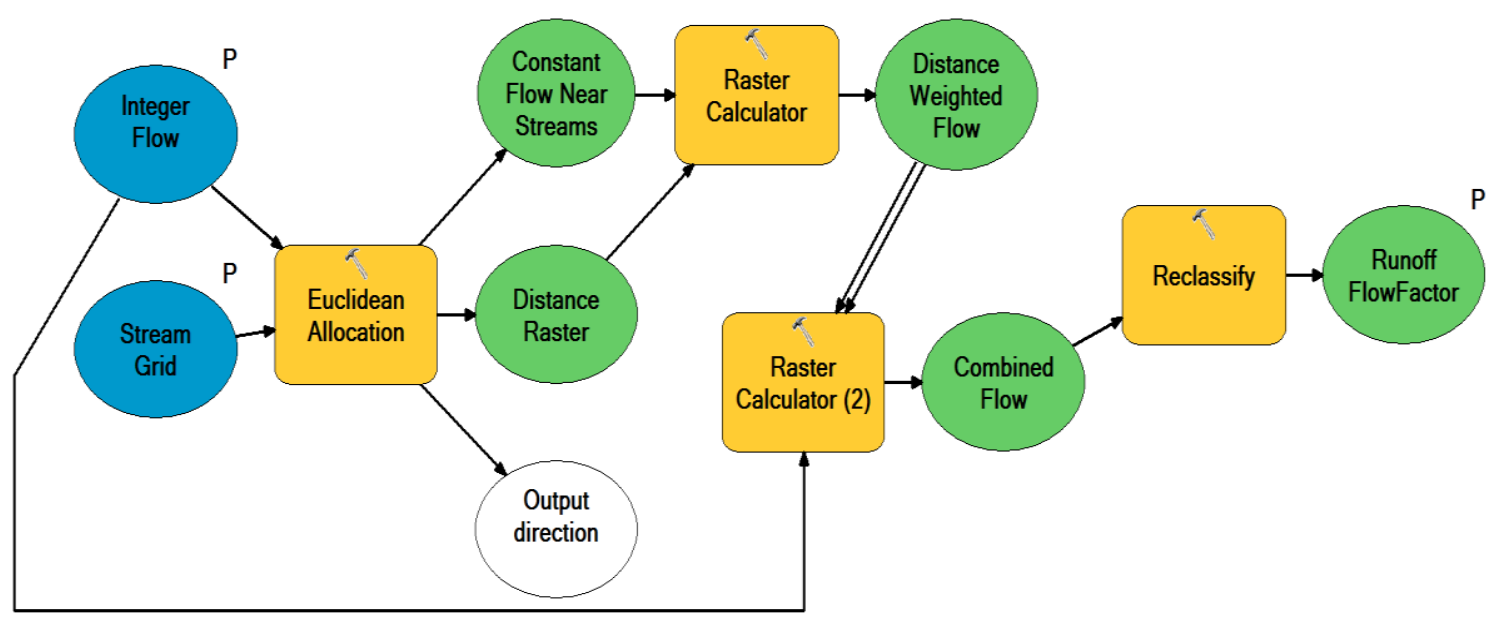

Figure A-11: Runoff factor model 


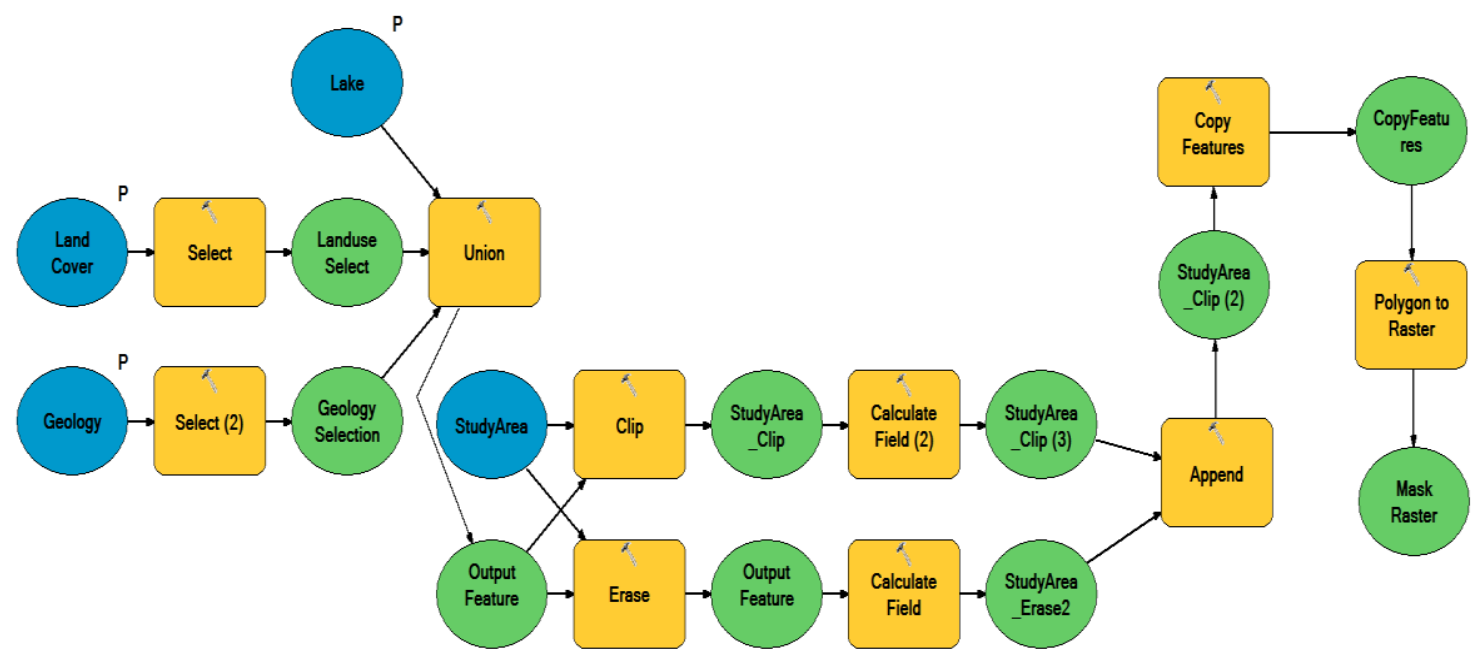

Figure A-12: Analysis mask model

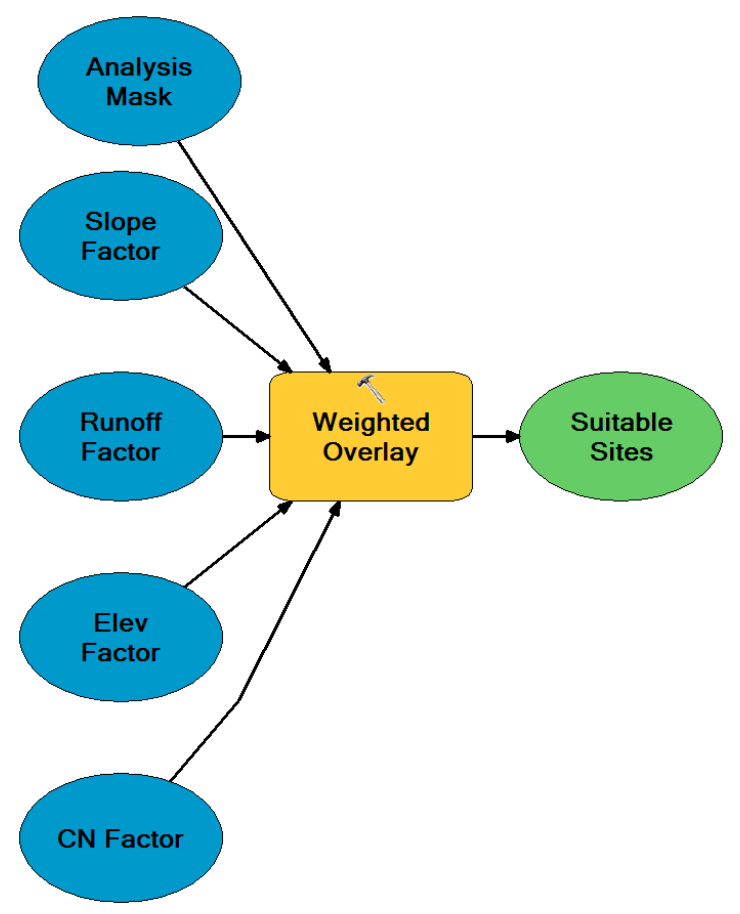

Figure A-13: Water capture suitability analysis model 


\section{Appendix B. Python Code to Check for Existence of Fields}

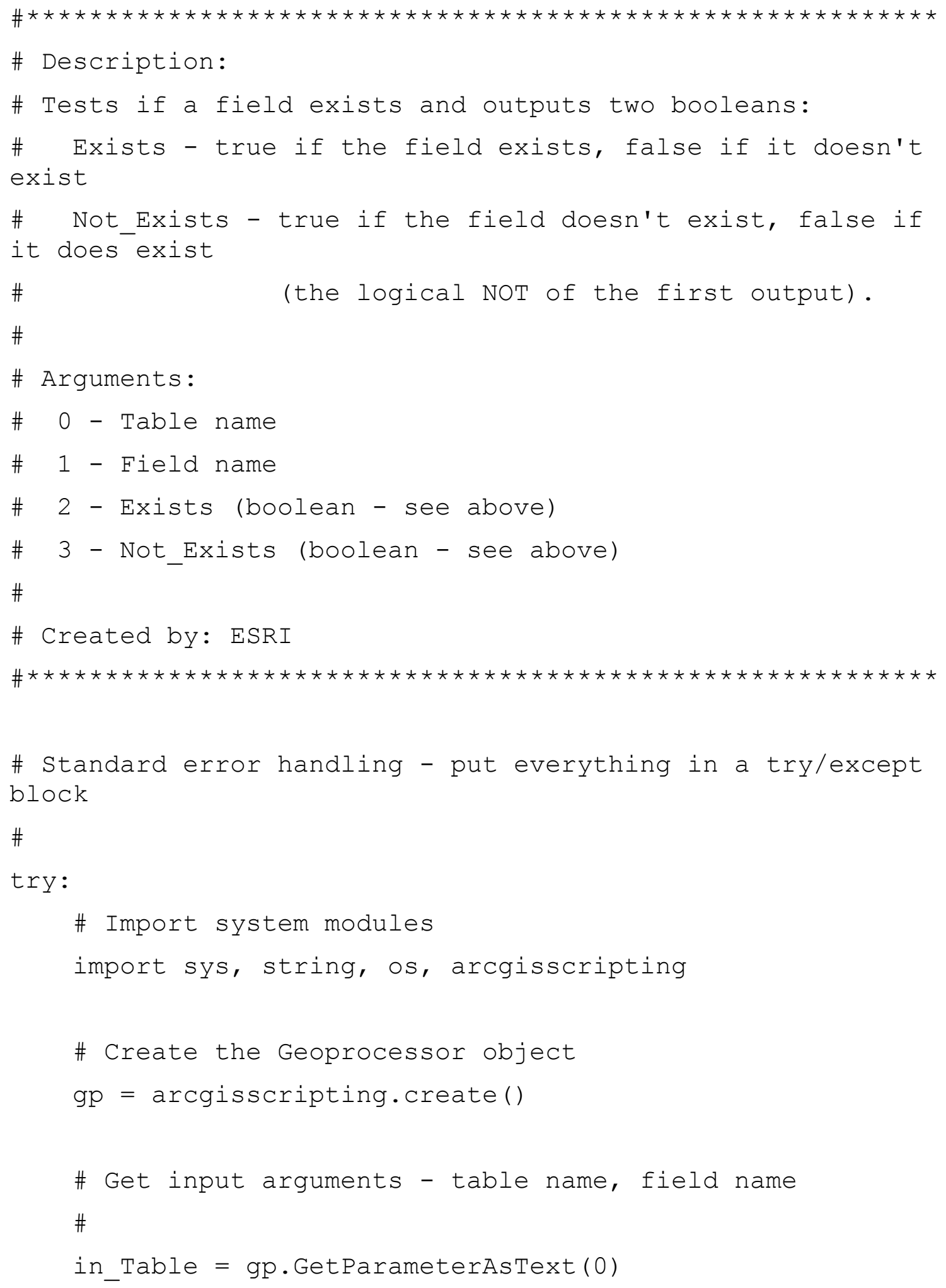




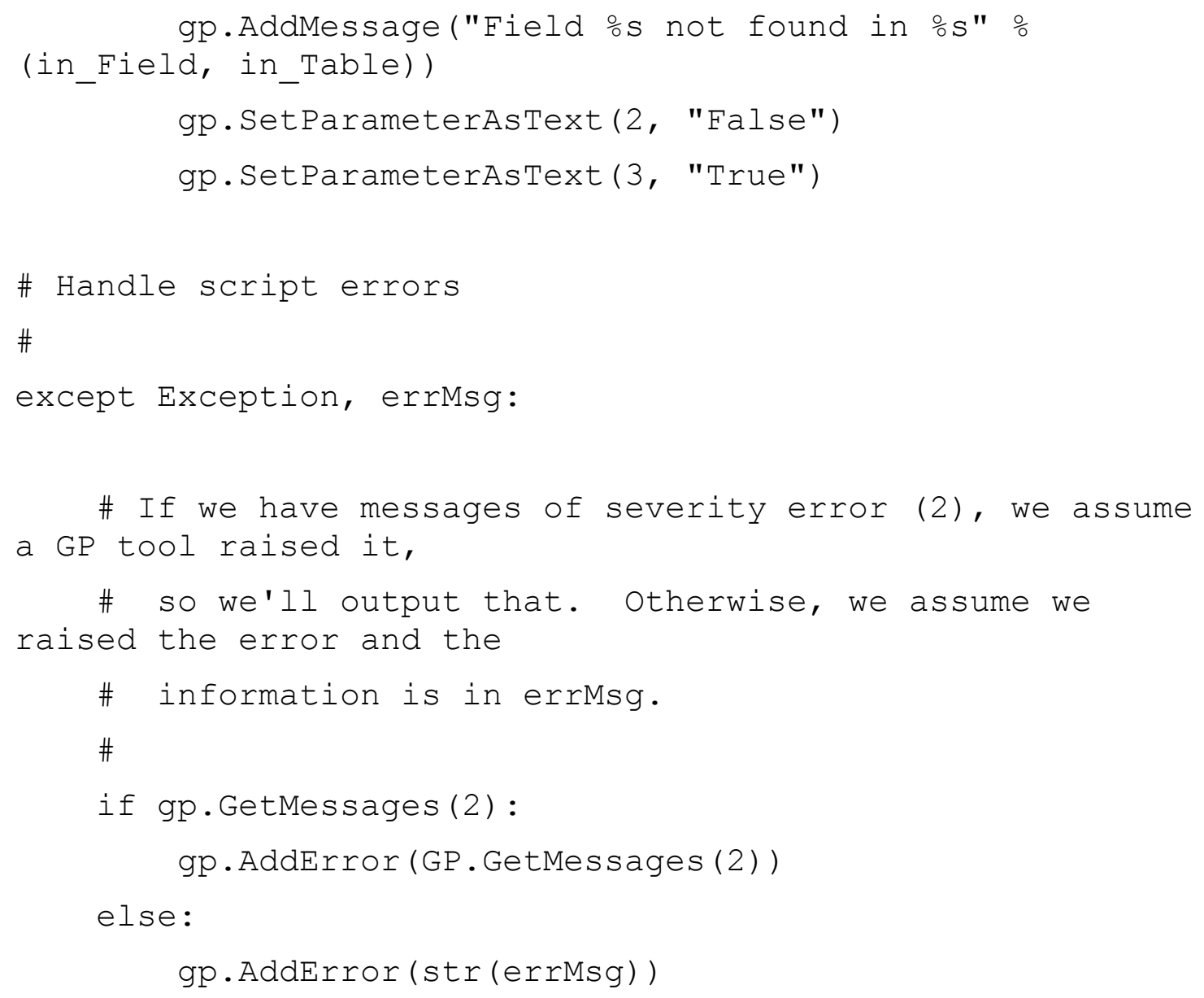




\section{Appendix C. Aggregated Peak Discharge Results}

Table 9. USGS method aggregated HUC basins results

\begin{tabular}{|l|l|r|r|r|r|r|}
\hline $\begin{array}{l}\text { Basin } \\
\text { Name }\end{array}$ & $\begin{array}{l}\text { 2 Year } \\
\text { Peak } \\
\text { Discharge } \\
\text { (cfs) }\end{array}$ & $\begin{array}{l}\text { Percent } \\
\text { Increase }\end{array}$ & $\begin{array}{l}\text { 10 Year } \\
\text { Peak } \\
\text { Discharge } \\
\text { (cfs) }\end{array}$ & $\begin{array}{l}\text { Percent } \\
\text { Increase }\end{array}$ & $\begin{array}{l}\text { 100 Year } \\
\text { Peak } \\
\text { Discharge } \\
\text { (cfs) }\end{array}$ & $\begin{array}{l}\text { Percent } \\
\text { Increase }\end{array}$ \\
\hline $\begin{array}{l}\text { Bicycle } \\
\text { Lake }\end{array}$ & 369.41 & 79.50 & 7090.91 & 68.50 & 38593.18 & 53.02 \\
\hline $\begin{array}{l}\text { Langford } \\
\text { Lake }\end{array}$ & 189.90 & 33.7 & 3650.49 & 30.1 & 19916.47 & 23.90 \\
\hline
\end{tabular}

Table 10. Table 10 Curve Number method aggregated HUC basins results

\begin{tabular}{|l|l|l|l|l|l|l|l|l|}
\hline $\begin{array}{l}\text { Basin } \\
\text { Name }\end{array}$ & $\begin{array}{l}\text { Average } \\
\text { Peak } \\
\text { Discharge } \\
\text { (cfs) }\end{array}$ & $\begin{array}{l}\text { \% } \\
\text { Incr. }\end{array}$ & $\begin{array}{l}\text { 2 Year } \\
\text { Peak } \\
\text { Discharge } \\
\text { (cfs) }\end{array}$ & $\begin{array}{l}\text { \% } \\
\text { Incr. }\end{array}$ & $\begin{array}{l}\text { 10 Year } \\
\text { Peak } \\
\text { Discharge } \\
\text { (cfs) }\end{array}$ & $\begin{array}{l}\text { \% } \\
\text { Incr. }\end{array}$ & $\begin{array}{l}\text { 100 Year } \\
\text { Peak } \\
\text { Discharge } \\
\text { (cfs) }\end{array}$ & $\begin{array}{l}\text { \% } \\
\text { Incr. }\end{array}$ \\
\hline $\begin{array}{l}\text { Bicycle } \\
\text { Lake }\end{array}$ & 320.52 & 10.35 & 555.20 & 5.92 & 3272.02 & 1.54 & 8886.44 & 0.91 \\
\hline $\begin{array}{l}\text { Langford } \\
\text { Lake }\end{array}$ & 69.41 & 66.57 & 134.63 & 31.4 & 1104.31 & 4.55 & 3346.97 & 1.62 \\
\hline
\end{tabular}

